\title{
GiovanA MuRAMOTO
}

\section{Avaliação nutricional e do perfil lipídico de crianças e adolescentes, com processo inflamatório, em unidade de emergência de um hospital universitário}

Dissertação apresentada à Faculdade de Medicina da Universidade de São Paulo para obtenção do título de Mestre em Ciências

Programa de Pediatria

Orientador: Prof. Dr. Artur Figueiredo Delgado

SÃO PAULO

2014 
Dados Internacionais de Catalogação na Publicação (CIP)

Preparada pela Biblioteca da

Faculdade de Medicina da Universidade de São Paulo

Creprodução autorizada pelo autor

\section{Muramoto, Giovana}

Avaliação nutricional e do perfil lipídico de crianças e adolescentes, com processo inflamatório, em unidade de emergência de um hospital universitário / Giovana Muramoto. -- São Paulo, 2014.

Dissertação(mestrado)--Faculdade de Medicina da Universidade de São Paulo. Programa de Pediatria.

Orientador: Artur Figueiredo Delgado.

Descritores: 1.Lipoproteínas 2.Lipoproteínas HDL 3.Lipoproteínas LDL 4.Colesterol 5.HDL-colesterol 6.LDL-colesterol 7.Lipídeos 8.Gorduras 9.Inflamação 10.Infecção 11.Proteína C-reativa 12.Serviços médicos de emergência 13.Estado nutricional 14.Criança 15.Adolescente

USP/FM/DBD-458/14 


\section{DEDICATÓRIA}

Aos meus pais, João Shiguehiro e Helenice, exemplos de persistência e honestidade. Agradeço por todo esforço para dar oportunidade de estudo e formação profissional para cada um dos filhos.

Ao meu marido Petrônio, de quem tenho muito orgulho e admiração, seu companheirismo e paciência foram fundamentais.

Aos meus irmãos Juhei, Caterina, Francesca, Micaela e Estevão, meus grandes amigos e incentivadores.

A todos os meus familiares e amigos, que de alguma forma participaram deste processo, em especial a minha tia e madrinha Elisabete, minha fã numero um, e apoiadora incondicional.

Especialmente, à minha falecida avó Nena (Fortunata), ser humano que eu tanto admirava e por quem fui tão amada (saudades)!

Para minha filha Isabela. 


\section{AGRADECIMENTOS}

Às crianças e seus pais, que concordaram em participar deste estudo.

Ao meu orientador Dr. Artur Figueiredo Delgado, pela confiança, incentivo e paciência. Sempre muito gentil, presente e disponível seus ensinamentos foram fundamentais para realização deste trabalho. Agradeço a ele também como pediatra, por cuidar da saúde da minha filha com sabedoria e competência.

Ao Prof. Dr. Alfredo Elias Gilio, Diretor da Divisão de Clinica Pediátrica Hospital Universitário da USP e Dra. Eloisa Correa de Souza, Coordenadora do Pronto Socorro de Pediatria do Hospital Universitário da USP, por apoiarem e viabilizarem a execução deste trabalho.

À Prof. Dra. Marina Baquerizo Martinez, Diretora do Laboratório Clínico do Hospital Universitário da USP, e à Juliana Bannwart de Andrade Machado, Coordenadora Técnica do Laboratório Clínico do Hospital Universitário da USP, pela colaboração fundamental para realização dos exames laboratoriais.

A toda equipe de enfermagem do Pronto Atendimento de Pediatria e do Setor de Coletas do Hospital Universitário da USP, pela colaboração, gentileza e prestatividade na coleta das amostras dos pacientes.

A todos os amigos e colegas do Hospital Universitário da Universidade de São Paulo pela colaboração durante o período de pesquisa.

A todos os amigos do Hospital Infantil Darcy Vargas, pelo apoio e compreensão durante todo período do meu mestrado. 
Ao Prof. Dr. Raul Cavalcante Maranhão, diretor do Laboratório de Metabolismo de Lípides do Instituto do Coração (Incor), pela colaboração na execução do projeto de pesquisa.

Ao estatístico Rogério Prado Rucitto, pela realização da análise estatística.

À Mariza Kazue Umetsu Yoshikawa, bibliotecária do Instituto da Criança e Valéria Vilhena Lombardi, bibliotecária da FMUSP, pelo auxilio com a bibliografia.

Às secretarias do Instituto da Criança, Monica Souza, Adriana Trindade Bezerra, Denise Terezinha Costa e Rosangela Souza, pelo fundamental apoio.

À Maria Helena Vargas, pela dedicação a editoração do texto da dissertação. 
Esta dissertação está de acordo com as seguintes normas, em vigor no momento desta publicação:

Referências: adaptado de International Committee of Medical Journals Editors (Vancouver).

Universidade de São Paulo. Faculdade de Medicina. Serviço de Biblioteca e Documentação. Guia de apresentação de dissertações, teses e monografias.

Elaborado por Anneliese Carneiro da Cunha, Maria Julia de A. L. Freddi, Maria F. Crestana, Marinalva de Souza Aragão, Suely Campos Cardoso, Valéria Vilhena. $3^{a}$ ed. São Paulo: Divisão de Biblioteca e Documentações; 2011.

Abreviatura dos títulos dos periódicos de acordo com List of Journals Indexed in Index Medicus. 


\section{SUMÁRIO}

Lista de abreviaturas e siglas

Lista de figuras

Lista de quadros

Lista de gráficos

Lista de tabelas

Resumo

Abstract

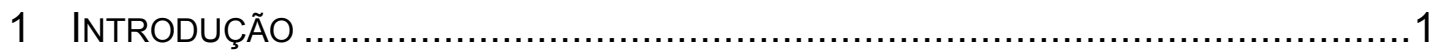

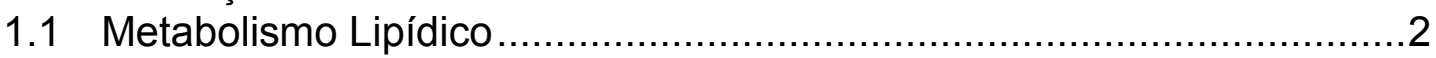

1.2 Alterações Lipídicas e Resposta Inflamatória.......................................

1.3 Lipoproteína de Alta Densidade .................................................. 12

1.4 Aterogenese e Alterações Lipídicas ………….................................13

1.5 Alterações Lipídicas e Estado Nutricional ...........................................17

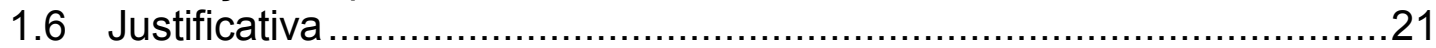

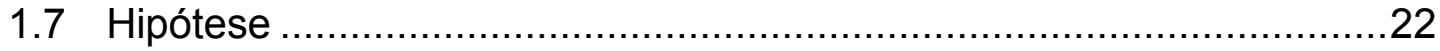

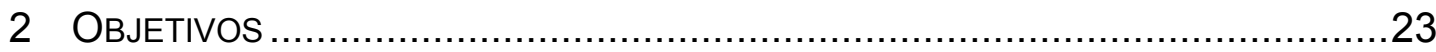

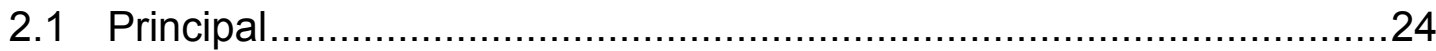

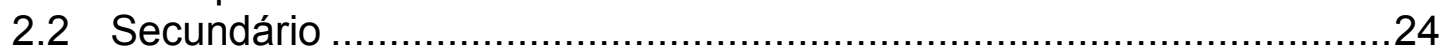

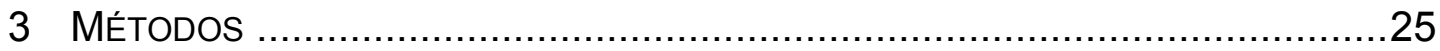

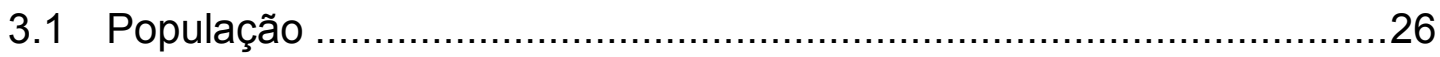

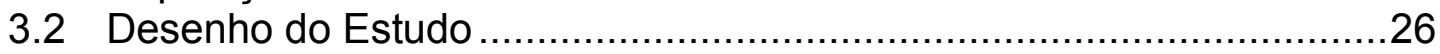

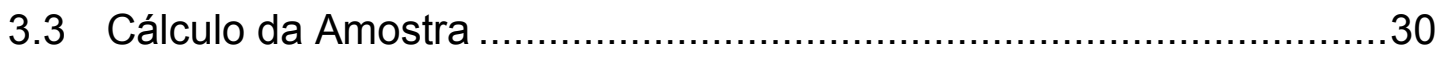

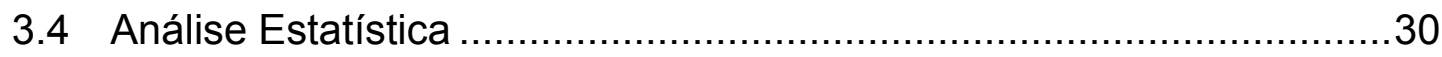

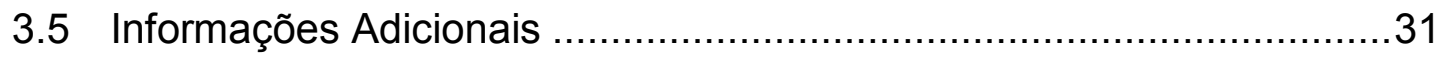

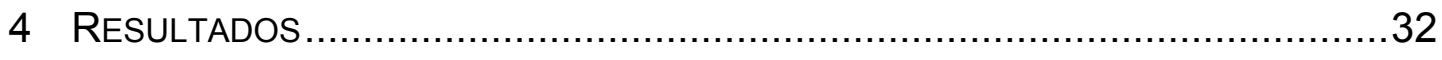

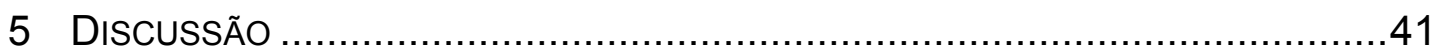

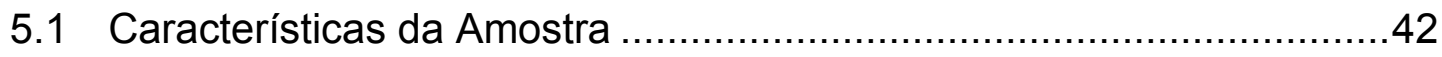

5.2 Analise das Diferenças entre Grupo I e II .......................................... 45

5.3 Alteração das Concentrações dos Lipídios Durante a
Inflamação e Suas Implicações ..........................................................46

5.4 Baixas Concentrações de HDL e a Aterogênese ................................49

5.5 Baixas Concentrações de HDL e Resposta Inflamatória........................51

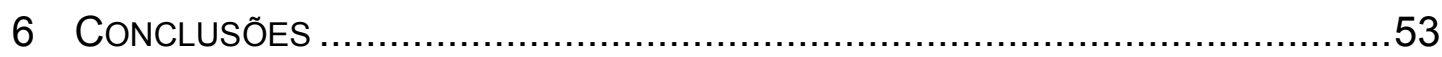

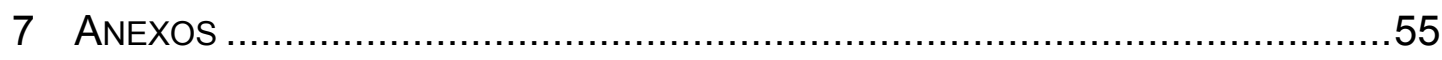

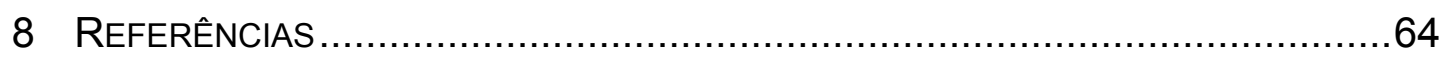

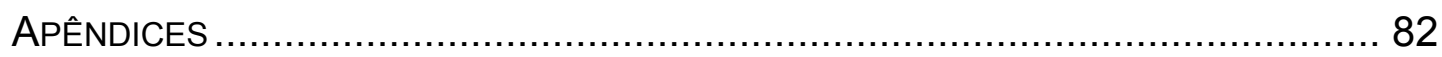




\section{LISTA DE ABREVIATURAS E SIGLAS}

\begin{tabular}{|c|c|}
\hline AG & - Ácidos graxos \\
\hline ALB & - Albumina \\
\hline apo & - Apoproteína \\
\hline CAPPesq & - Comissão de Ética para Análise de projetos de Pesquisa \\
\hline CT & - Colesterol total \\
\hline DAC & - Doença coronariana \\
\hline DP & - Desvio padrão \\
\hline HDL & - Lipoproteína de alta densidade \\
\hline HU-USP & - Hospital Universitário da Universidade de São Paulo \\
\hline IBGE & - Instituto Brasileiro de Geografia e Estatística \\
\hline IDL & - Lipoproteína de densidade intermediária \\
\hline IMC & - Índice de massa corpórea \\
\hline LCAT & - Lecitina colesterol acil transferase \\
\hline LDL & - Lipoproteína de baixa densidade \\
\hline Lp & - Lipoproteínas \\
\hline LPL & - Lipoproteína lípase \\
\hline NHANES & - National Health and Nutrition Examination Survey \\
\hline OMS & - Organização Mundial da Saúde \\
\hline PCR & - Proteína C reativa \\
\hline PCRus & - PCR ultrassensível \\
\hline PRISM & - Pediatric Risk of Mortality \\
\hline QM & - Quilomicrons \\
\hline SBC & - Sociedade Brasileira de Cardiologia \\
\hline SIRS & - Síndrome da resposta inflamatória sistêmica \\
\hline TCLE & - Termo de consentimento livre e esclarecido \\
\hline TG & - Triglicerídeo \\
\hline TNF- $\alpha$ & - Fator de necrose tumoral alfa \\
\hline UTI & - Unidade de terapia intensiva \\
\hline VLDL & - Lipoproteína de muito baixa densidade \\
\hline
\end{tabular}




\section{LISTA DE FIGURAS}

Figura 1 - Representação esquemática das lipoproteínas LDL e HDL...........4

Figura 2 - Representação esquemática da placa aterosclerótica em vaso sanguíneo arterial ..................................................... 14

Figura 3 - Fluxograma do desenho do estudo .......................................29 


\section{LISTA DE QUADROS}

Quadro 1 - Valores de referência dosagem de lipídios em crianças de 2 a 19 anos de idade segundo a Sociedade Brasileira de Cardiologia

Quadro 2 - Recomendação da SBC para dosagem de lipídios em crianças e adolescentes de 2 a 19 anos de idade.

Quadro 3 - Fármacos utilizados no tratamento das dislipidemias na criança e adolescentes 


\section{LISTA DE GRÁFICOS}

Gráfico 1 - Resultado dos principais indicadores do perfil lipídico (CT, LDL, TG, HDL) na amostra total ....................................................34

Gráfico 2 - Regressão linear mostrando correlação entre as variáveis

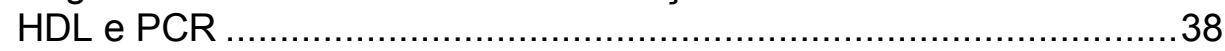

Gráfico 3 - Regressão linear mostrando correlação entre as variáveis TG e PCR 


\section{LISTA DE TABELAS}

Tabela 1 - Estado nutricional e modificações nas concentrações dos lipídios séricos.

Tabela 2- Distribuição dos pacientes de acordo com estado nutricional e as concentrações de CT acima do desejável e HDL abaixo do desejável

Tabela 3 - Estado nutricional em cada faixa etária na amostra total 36

Tabela 4 - Faixa etária e modificações do perfil lipídico 36

Tabela 5 - Resultado do teste t-Student na comparação entre os grupos I e II de acordo com as variáveis: idade, glicemia, estado nutricional, perfil lipídico e concentrações de albumina

Tabela 6 - Resultado das correlações entre as variáveis analisadas nas crianças e adolescentes do Grupo I (PCR $\geq 5 \mathrm{mg} / \mathrm{L}$ )

Tabela 7 - Resultado dos modelos de regressão das variáveis de perfil lipídico e concentrações de albumina segundo a variável PCR 


\section{RESUMO}

Muramoto G. Avaliação nutricional e do perfil lipídico de crianças e adolescentes, com processo inflamatório, em unidade de emergência de um hospital universitário [dissertação]. São Paulo: Faculdade de Medicina, Universidade de São Paulo; 2014.

Objetivo: comparar o perfil lipídico de em crianças e adolescentes, com e sem inflamação, atendidas num pronto atendimento geral de pediatria de um hospital universitário de nível de atendimento secundário, segundo estado nutricional, sexo e idade. Métodos: Estudo transversal, realizado entre outubro de 2012 e agosto de 2013, avaliou 124 crianças e adolescentes (3 meses a 14 anos de idade) em atendimento na unidade de emergência do Hospital Universitário da Universidade de São Paulo, com queixa relacionada a processo inflamatório/infeccioso. Os pacientes foram separados em dois grupos de acordo com os níveis de proteína $C$ reativa (PCR): grupo I se maior ou igual a $5 \mathrm{mg} / \mathrm{L}$, e grupo II se menor que $5 \mathrm{mg} / \mathrm{L}$. Dosagens de colesterol total, lipoproteína de alta densidade (HDL) e baixa densidade (LDL), triglicerídeos e albumina foram comparadas entre os dois grupos, levando em conta o estado nutricional (avaliado através de medidas antropométricas), gênero e idade. Resultado: A mediana de idade foi de 51 meses, com maioria dos pacientes classificados como eutróficos (76,5\%). Do total da amostra, $34,7 \%$ dos pacientes apresentaram colesterol total e/ou triglicerídeos alterados e $67 \%$ apresentaram baixos níveis de HDL. Não houve diferença significativa do perfil lipídico entre os dois grupos de pacientes separados de acordo com PCR. Dentre os pacientes com PCR $\geq$ $5 \mathrm{mg} / \mathrm{L}$, a PCR apresentou correlação inversa com HDL [r= (-)0,363 e $p=0,001]$, com LDL [r= (-) 0,235 e p=0,034], com albumina [r= (-) 0,308 e $p=0,005]$ e correlação direta com TG $(r=0,426$ e $p>0,001)$. Na analise de regressão linear, se evidenciou que para cada aumento de $1 \mathrm{mg} / \mathrm{L}$ nos 
valores da PCR espera-se uma redução média de 0,072 mg/dL da HDL, de $0,083 \mathrm{mg} / \mathrm{dL}$ da $\mathrm{LDL}$, de $0,002 \mathrm{~g} / \mathrm{dL}$ de albumina, e um aumento médio de $0,564 \mathrm{mg} / \mathrm{dL}$ do triglicerídeo. Conclusão: Pacientes com processo inflamatório apresentam alterações nos níveis séricos do HDL, LDL e triglicerídeos que se relacionam com o grau de inflamação, de forma independente do estado nutricional.

Descritores: Lipoproteínas. Lipoproteínas HDL. Lipoproteínas LDL. Colesterol. HDL-colesterol. LDL-colesterol. Lipídeos. Gorduras. Inflamação. Infecção. Proteína C-reativa. Serviços médicos de emergência. Estado nutricional. Criança. Adolescente. 


\begin{abstract}
Muramoto G. Nutritional assessment and lipid profile of children and adolescents, with inflammatory process, in emergency department of a university hospital [dissertation]. São Paulo: "Faculdade de Medicina, Universidade de São Paulo"; 2014.
\end{abstract}

Aim: To compare the lipid profile in children and adolescents with and without inflammation, met a ready general pediatric service of a university hospital secondary care level, according to nutritional status, gender and age. Methods: Cross-sectional study conducted between October 2012 and August 2013, assessed 124 children and adolescents (3 months to 14 years old) in the emergency department of the University Hospital of the University of São Paulo, with reports of inflammatory/ infectious process. The patients were divided into two groups according to the $\mathrm{C}$ reactive protein (CRP) levels: group I is higher than or equal to $5 \mathrm{mg} / \mathrm{L}$, and Group II was lower than $5 \mathrm{mg} / \mathrm{L}$. Total cholesterol, high density lipoprotein (HDL) and low density lipoprotein (LDL), triglycerides and albumin were compared between the two groups, taking into account the nutritional status (assessed by anthropometric measurements), gender and age. Results: The median age was 51 months, with patients mostly classified as well-nourished (76.5\%). Of the overall sample, $34.7 \%$ of patients had total cholesterol and/or triglycerides altered and $67 \%$ had low levels of HDL. There was no significant difference in lipid profile between the two groups of PCR. For the patients with $\mathrm{CPR} \geq 5 \mathrm{mg} / \mathrm{L}, \mathrm{CPR}$ presented an inverse correlation with HDL $[\mathrm{r}=(-)$ 0.363 and $p=0.001]$, with LDL $[r=(-) 0.235$ and $p=0.034]$, with [ $r=$ albumin (-) 0.308 and $p=0.005]$ and direct correlation with TG $(r=0.426$ and $p$ $<0.001)$. Linear regression analysis it became clear that for each increase of $1 \mathrm{mg} / \mathrm{L}$ in the values of CRP expected an average reduction of $0,072 \mathrm{mg} / \mathrm{dL}$ of $\mathrm{HDL}$, the $0,083 \mathrm{mg} / \mathrm{dL}$ of $\mathrm{LDL}$, the $0,002 \mathrm{~g} / \mathrm{dL}$ albumin, and an average 
increase of $0,564 \mathrm{mg} / \mathrm{dL}$ of triglycerides. Conclusion: Patients with an inflammatory process exhibit changes in the serum levels of the lipids HDL, LDL and TG that are related to the degree of inflammation. These changes occurred regardless of nutritional status.

Descriptors: Lipoproteins. Lipoproteins,HDL. Lipoproteins, LDL. Cholesterol. Cholesterol, HDL. Cholesterol, LDL. Lipids. Fats. Inflammation. Infection. C-reactive protein. Emergency medical services. Nutritional status. Child. Adolescent. 
1 INTRODUÇÃO 


\subsection{Metabolismo Lipídico}

A palavra lipídio é derivada do grego "lipos" que significa gordura. As gorduras podem se apresentar de diferentes formas: óleos (forma líquida), gorduras propriamente ditas (forma sólida), ceras (ésteres formados a partir de ácidos graxos e alcoóis), esteróis (colesterol e hormônios sexuais) e sabões, detergentes e sais biliares (Mahley et al., 2010).

A função básica das gorduras no organismo humano é o armazenamento e fornecimento de energia de alta densidade, ou seja, 9,3 kcal para cada grama de lipídio. Elas têm, porém diversas outras funções como a manutenção da temperatura corporal e a proteção mecânica de ossos e órgãos. São componentes estruturais das células principalmente da camada fosfolipídica, transportam vitaminas lipossolúveis, participam da síntese de hormônios, síntese de mediadores inflamatórios, participam do processo inflamatório e do estresse oxidativo (Torrinhas et al., 2009).

As gorduras são compostas por grupos de ácidos graxos que são ácidos carboxílicos com cadeias não ramificadas, formadas por número par de átomos carbonos que são unidos por ligação simples ou dupla. Os ácidos graxos são obtidos pelo organismo através da digestão e absorção das gorduras da dieta, mas também podem ser sintetizados a partir da glicose e aminoácidos pelo fígado, tecido adiposo e glândulas mamarias (De Angelis, 2007). 
Os lipídios são armazenados no organismo humano na forma de triglicerídeos (TG) que são constituídos de triésteres de ácidos graxos acoplados a uma molécula de glicerol. Eles são a principal forma de armazenamento de energia no tecido adiposo e muscular. São transportados no interior das lipoproteínas (Lp) na circulação sanguínea/linfática, hidrolisados para liberação de ácidos graxos livres e utilizados como fonte de energia. O aumento da dosagem sérica de TG geralmente decorre de um aumento na circulação de partículas ricas em triglicerídeos: os quilomicrons (QM) ou as lipoproteínas de muito baixa densidade (VLDL) (Mahley et al., 2010).

Lipoproteínas são estruturas esféricas constituídas de uma camada externa hidrófila composta por proteínas, colesterol e fosfolipídios mais um núcleo de lipídios hidrofóbicos compostos por triglicerídeos e ésteres de colesterol (Figura 1). As lipoproteínas são produzidas principalmente no fígado, mas também podem ser formadas nos intestinos e circulação linfática. Elas podem ser estruturadas na forma de quilomicrons, na forma de VLDL, lipoproteína de densidade intermediária (IDL), lipoproteínas de baixa densidade (LDL), lipoproteínas de alta densidade (HDL) e lipoproteína-a [Lp (a)]. As proteínas pertencentes à estrutura das lipoproteínas são chamadas de apoproteínas (apo) (Torrinhas et al., 2009). 


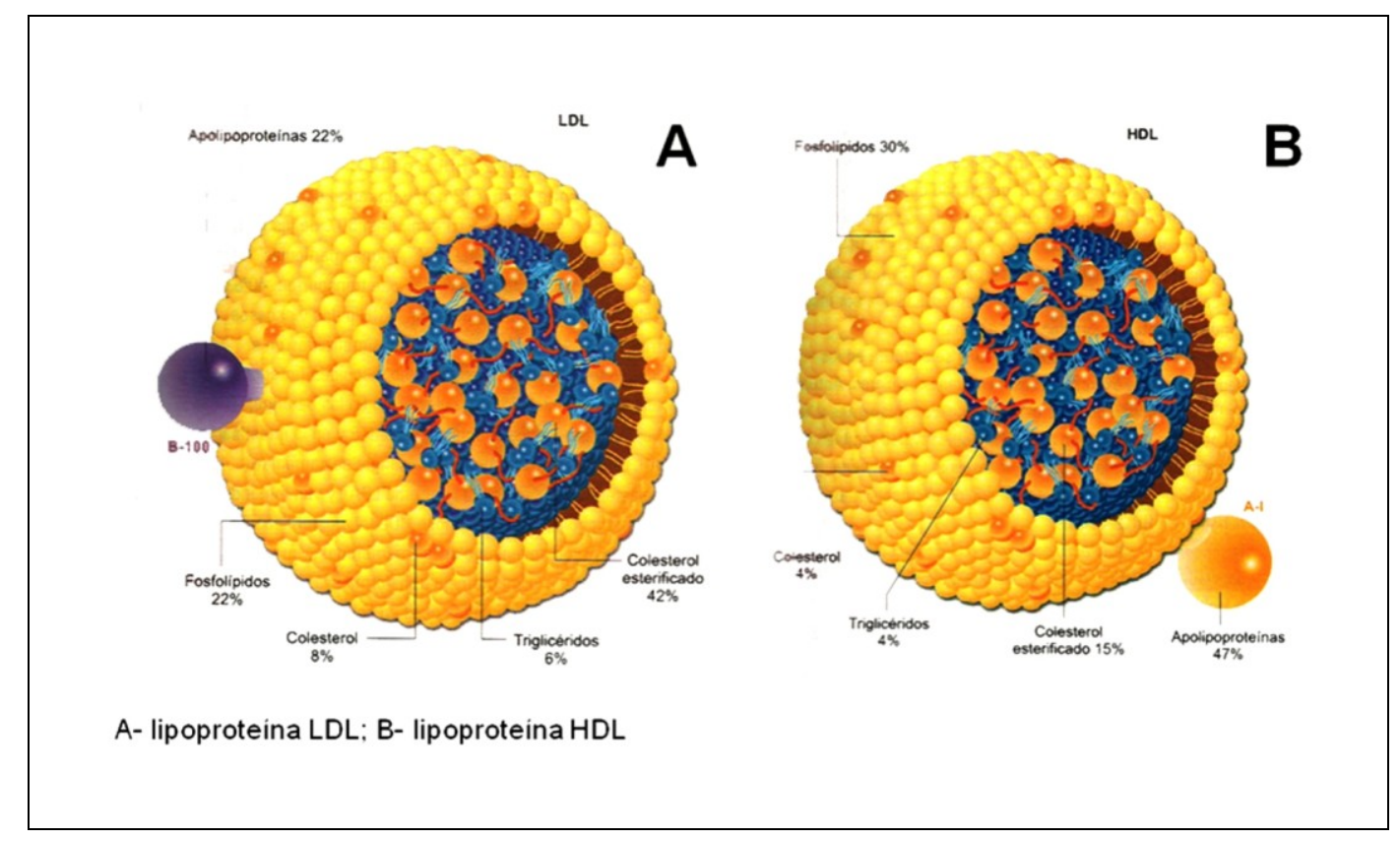

Figura 1 - Representação esquemática das lipoproteínas LDL e HDL [Fonte: Lépori (2003)]

Os quilomicrons são partículas que transportam lipídios oriundos da dieta através do sistema linfático. Estes lipídios, na corrente sanguínea, após passagem pelo fígado, são transportados principalmente na forma de VLDL, mas também de IDL e LDL. Dentre as lipoproteínas, as VLDL são partículas maiores em tamanho e de menor densidade. Elas são produzidas pelo fígado e transportam grande quantidade de TG. Durante a circulação sanguínea da VLDL, os TG são hidrolisados pela lípase lipoproteica e os ácidos graxos (AG) são liberados para os tecidos. Parte das VLDL dá origem às IDL, que são rapidamente removidas da circulação (Torrinhas et al., 2009).

Outra parte das VLDL dá origem também às LDL que são estruturas menores que as VLDL e IDL, compostas por colesterol, pequena quantidade TG e de apoproteínas (apo B100 ou apo CIII). As LDL permanecem por longo período na circulação até serem removidas pelo fígado. O acúmulo e a 
oxidação das LDL estimulam o surgimento de moléculas de adesão leucocitária na superfície endotelial. Monócitos e linfócitos são, então, atraídos e aderidos à parede endotelial e migram para o espaço subendotelial, e na forma de macrófagos captam a LDL oxidada, transformando-se em células espumosas. Mediadores inflamatórios estimulam a proliferação e migração de células musculares lisas da camada média para a íntima onde contribuem para a formação da capa fibrosa da placa aterosclerótica. A ruptura desta capa expõe material lipídico altamente trombogênico o que pode levar a formação de trombo sobrejacente (Hansson, 2005).

A HDL é formada por cerca de $50 \%$ de lipídios (fosfolipídios, colesterol, colesterol esterificado, TG) e 50\% de proteínas. As principais apoproteínas ligadas às HDL são apo Al e All. A HDL é sintetizada principalmente no fígado, mas também no intestino e na circulação. Ela é responsável pela esterificação e transporte reverso do colesterol (transporte do colesterol dos tecidos para o fígado) (Tall, 1990). Neste processo a HDL absorve o excesso de colesterol através das células espumosas na placa aterosclerótica. A proteção dos vasos contra a aterogênese por ação da HDL também se dá através da remoção de lipídeos oxidados da LDL, inibição da fixação de moléculas de adesão ao endotélio e estimulação da liberação de oxido nítrico (Rosenson et al., 2012).

As apoproteínas se encontram associadas a lipoproteínas específicas, agindo como cofatores enzimáticos e receptores de membrana (Mahley et al., 1984). Fazem parte das lipoproteínas vários tipos diferentes de apoproteínas [AI, AII, AIV, AV, B100, B48, CI, CII, CII, E, apo (a) e D]. A apo 
Al é uma apoproteína sintetizada pelo intestino e fígado, e é constituinte dos quilomicrons e do HDL. Alem de sua função estrutural a apo Al se liga a lecitina colesterol acil transferase (LCAT), que esterifica o colesterol livre nas partículas de HDL. A LCAT também pode ser ativada pelas apo IV e apo Cl. Partículas de HDL e precursores como pré-BHDL funcionam como aceptores de colesterol liberado pelas células. O efluxo de colesterol para HDL representa parte da via de transporte reverso de colesterol. Esta via leva o colesterol dos tecidos periféricos de volta para o fígado. A apo Al funciona como proteína de reconhecimento para ligação com a "ATP binding cassette transporter Al" (ABCA1, ABCG1, ABCG4), os quais modulam o efluxo de colesterol das células (macrófagos) para o HDL. Também tem capacidade de reconhecimento e ligação com o "scavenger receptor" tipo I classe B (SRBI) que modula a captação de colesterol para o fígado. Apo All é sintetizada principalmente pelo fígado. Ela é encontrada junto com apo Al em uma subfração de HDL. Sua função está ligada principalmente à ativação da lípase hepática e inibição da LCAT. A apo All é considerada uma apoproteína pró-aterogênica (Fruchart e Ailhaud, 1992; Mahley et al., 2010).

A apo B100 é produzida pelo fígado e serve como proteína estrutural das lipoproteínas VLDL, IDL e LDL. Ela funciona como um ligante do receptor de LDL. A apo B-48 é produzida no intestino e é constituinte estrutural dos quilomicrons. Ela não se liga ao receptor de LDL. A apo E é a principal responsável pela remoção de VLDL e IDL mediada por receptores. Ela é sintetizada principalmente pelo fígado, mas também por astrócitos, neurônios cerebrais, macrófagos, células da musculatura lisa arterial e queratinócitos. Apoproteína $\mathrm{Cl}, \mathrm{Cll}$ e apo Clll são sintetizadas principalmente 
pelo fígado, mas também por macrófagos e intestino em pequena quantidade. A apo $\mathrm{Cl}$ funciona como ativador da LCAT. As apo $\mathrm{Cl}$ e CIII podem deslocar a apo $\mathrm{E}$ da superfície, interferindo, portanto no clearance das lipoproteínas. A apo CII atua como cofator da lipoproteína lípase (LPL). A apo CIII tem efeitos considerados pró-aterogenicos, dentre ele inibe a hidrolise de TG pela lípase hepática e LPA. Apo V é produzida pelo fígado e afeta profundamente as concentrações de triglicerídeos. É um potente ativador da lipólise mediada pela LPL e inibe a produção hepática de VLDL (Gotto, 1990; Mahley et al., 2010).

\subsection{Alterações Lipídicas e Resposta Inflamatória}

Durante o processo inflamatório agudo ocorrem alterações na concentração e composição dos lipídios e lipoproteínas plasmáticas. A produção de $A G$ tem como finalidade principal suprir as necessidades energéticas dos hepatócitos no fígado, do miocárdio e da musculatura esquelética. Os lipídios também participam da produção de mediadores inflamatórios e imunológicos. A intensidade da lipólise e mobilização dos lipídios é dependente do grau de hipermetabolismo e inflamação (Oliveira, 2005)

A intensidade da inflamação pode ser estimada pelas proteínas de fase aguda, que são proteínas cujas concentrações na circulação sanguínea variam durante o estado inflamatório (infecção, trauma, neoplasias, doenças reumáticas, etc.). Existem diversas substancias que apresentam esta característica tais como a proteína $\mathrm{C}$ reativa $(\mathrm{PCR})$, procalcitonina, alfa-1 
anti-tripsina, ferritina, haptoglobina, interleucinas, albumina e transferrina (Gabay et al., 1997; Nijsten e Olinga, 2000; Nemeth et al., 2002). Na prática clínica a dosagem de PCR é a mais utilizada para quantificação do grau de inflamação devido à disponibilidade de dosagem laboratorial e ao menor custo em relação às outras proteínas de fase aguda (Delgado et al., 2008).

A proteína C reativa é uma proteína (pentraxina) produzida pelos hepatócitos durante a fase aguda da resposta inflamatória. Sua produção é estimulada principalmente pelas citocinas pró-inflamatórias Interleucina-6 e Interleucina1ß, em interação com diversas outras citocinas. A PCR tem participação fundamental na primeira linha de defesa com ativação do sistema complemento e de células fagocíticas durante processos infecciosos, principalmente de origem bacteriana. Durante processos infecciosos de origem viral, a PCR também tem sua produção estimulada em menor intensidade, assim como em situações de inflamação de origem não infecciosa como, por exemplo, na presença de neoplasias, doenças reumáticas, obesidade, estados alérgicos, doenças cardiovasculares, dentre outras (Black et al., 2004).

As alterações nas concentrações das proteínas de fase aguda na circulação se dão em diversas magnitudes. Os componentes do sistema complemento, por exemplo, aumentam cerca de $50 \%$ em situações de inflamação sistêmica, enquanto a PCR pode ter um aumento de cerca de 1000 vezes na sua concentração. O aumento da PCR, assim como das demais proteínas inflamatórias, não se dá de forma uniforme em todos os pacientes com a mesma doença, existindo uma regulação individual da sua produção (Gabay e Kushner, 1999). 
A PCR é, portanto, um marcador inflamatório inespecífico. Valores menores que $1 \mathrm{mg} / \mathrm{L}$ refletem um estado de inflamação leve que podem estar associados às variações genéticas, diferentes hábitos alimentares, tabagismo, hipertensão arterial, diabetes melito ou a estados clínicos considerados não inflamatórios (Kushner et al., 2006). Para doença cardiovascular, inclusive, existe uma estratificação de risco de acordo com a dosagem de PCR, sendo considerado alto risco os pacientes com níveis acima de $0,3 \mathrm{mg} / \mathrm{L}$ (Pearson et al., 2003). As infecções bacterianas estão associadas a valores de PCR acima de $5 \mathrm{mg} / \mathrm{L}$ (Flanders et al., 2004). Valores de PCR acima de $10 \mathrm{mg} / \mathrm{L}$ em adultos com pneumonia estão associados a infecções mais graves e de pior prognostico. A persistência de concentrações de PCR aumentadas, durante o tratamento infeccioso, também está associada à falha terapêutica e a complicações (Smith et al., 1995). Em pacientes adultos, níveis de PCR à admissão em Unidade de Terapia Intensiva (UTI) maiores do que $10 \mathrm{mg} / \mathrm{dL}$ estão relacionados à disfunção orgânica e a maior taxa de mortalidade (Lobo et al., 2003).

Diversos estudos experimentais têm demonstrado o benefício de níveis mais altos de $\mathrm{HDL}$ e de apo $\mathrm{Al}$ (principal apoproteína ligada à $\mathrm{HDL}$ ) na circulação e melhor resposta imunológica frente a quadros de infecção sistêmica grave. A administração de apo Al em animais com infecção grave reduziu a produção de mediadores inflamatórios e a mortalidade em alguns desses estudos (Hudgins et al., 2003; Imai et al., 2003; Berbée et al., 2006; Jiao e Wu, 2008; Guo et al. 2013).

Pacientes adultos com inflamação sistêmica grave, que cursam com o aumento de proteínas de fase aguda e citocinas, apresentam alterações 
agudas no perfil lipídico. Estas alterações se caracterizam pela diminuição dos níveis de HDL, CT, LDL e aumento dos níveis de TG na circulação (Alvarez e Ramos, 1986).

Em situações de estresse metabólico como na síndrome da resposta inflamatória sistêmica (SIRS) as alterações lipídicas de apo Al se relacionaram com maior tempo de internação na Unidade de Terapia Intensiva (Chenaud et al., 2004).

Durante processos infecciosos com sepse ocorre uma redução dos níveis de HDL e LDL, bem como elevação dos níveis de TG durante os primeiros três dias da admissão, com inicio da recuperação dos níveis das lipoproteínas após o terceiro dia (van Leeuwen et al., 2003). As alterações do perfil lipídico durante a infecção são mais acentuadas nas primeiras 72 horas, mas podem levar mais do que sete dias para retornarem aos valores anteriores à infecção (Gidding et al., 1998).

Os pacientes com alterações das dosagens de lipoproteínas a admissão na UTI se correlacionaram inversamente com dosagens de interleucina-6 e tiveram significativamente maior tempo de internação e uma maior taxa de mortalidade (Chien et al., 2005). Alterações agudas das dosagens de lipoproteínas com redução significativa de HDL e de apo Al também se correlacionam com maior pontuação nos escores de gravidade em pacientes gravemente doentes (Gordon et al., 2001).

Além da associação das modificações do perfil lipídico durante a infecção relacionado com a resolução do quadro séptico, a inflamação sistêmica em humanos também altera o metabolismo do $\mathrm{HDL}$, o que pode 
levar a um remodelamento desta lipoproteína, favorecendo processos aterogênicos independente dos níveis prévios de HDL e apo Al (de la Llera Moya et al., 2012).

Em pediatria poucos estudos relacionaram inflamação e infecção às alterações no perfil lipídico, mostrando alterações similares às evidenciadas em adultos (Yildiz et al., 2009). Em crianças com sepse meningocócica, foi evidenciado que baixas dosagens de CT, HDL e LDL nas primeiras 24horas de admissão em UTI, se relacionaram maior mortalidade e maior pontuação no escore de gravidade Pediatric Risk of Mortality (PRISM). Os níveis de lipoproteínas se normalizaram cerca de um três meses após admissão na unidade de terapia intensiva (Vermont et al., 2005).

Foram poucos estudos também que relacionaram estado de inflamação leve com perfil lipídico em pediatria. Na Suécia, escolares e adolescentes em acompanhamento ambulatorial tiveram níveis de $\mathrm{CT}, \mathrm{HDL}$ e LDL coletados durante período de infecção leve e comparados com valores coletados na rotina três anos antes. Os valores de HDL, LDL e CT foram significativamente menores no grupo com infecção em relação às dosagens anteriores, sendo esta diferença mais acentuada nos pacientes com PCR aumentado (Aburawi et al., 2006). Este dado preocupa quando nos deparamos com o risco de que a redução significante dos níveis de HDL nas primeiras 24 horas de infecção, mesmo com recuperação nos meses subsequentes, possa levar a um espessamento da camada intima da carótida (Liuba et al., 2003). 


\subsection{Lipoproteína de Alta Densidade}

Dentre as lipoproteínas plasmáticas, as partículas de HDL têm como característica estrutural serem as menores em tamanho, porém as de maior densidade, por conterem grande quantidade de proteínas. Sua composição é modificada durante seu metabolismo podendo se apresentar como Pré $\beta$ $\mathrm{HDL}, \mathrm{HDL}_{2}$ e $\mathrm{HDL}_{3}$ (Soran et al., 2012). As apoproteínas pertencentes a estas lipoproteínas também podem ter diferentes isoformas fazendo com que existam, portanto, HDL com diferentes características (Karlsson et al., 2005). Através de analise proteômica, foi identificado que pacientes portadores de artrite reumatoide têm HDL com composição proteica comum entre si. O mesmo ocorre em outras situações como na doença coronariana, insuficiência renal crônica e psoríase. Esta informação ressalta a importância de se estudar outras funções da HDL na inflamação, ainda desconhecidas (Marsche et al., 2013).

A HDL tem propriedades anti-inflamatórias durante a infecção como a neutralização de lipopolissacárides (através da apo Al), sobre monócitos/macrófagos (inibição da apresentação de antígenos) e supressão da produção de citocinas/quimiocinas. Ela pode ser enriquecida de proteínas ligadas à resposta inflamatória de fase aguda, metabolismo lipídico, ativação do sistema complemento, regulação do fator de crescimento tumoral e proteólise (Soran et al., 2012; Marsche et al., 2013).

A HDL tem um importante papel como modulador da resposta inflamatória e também exerce um papel relevante na neutralização de lipopolissacarides durante a infecção bacteriana (Murch et al., 2006). Alguns 
fatores como a diminuição da produção do colesterol, sua utilização para clareamento dos mediadores inflamatórios, a hemodiluição podem contribuir para alteração da concentração das lipoproteínas nos pacientes com SIRS e sepse (Chiarla et al., 2010). Um estudo dosou HDL em 1719 pacientes adultos internados e concluiu que para cada aumento de $1 \mathrm{mg} / \mathrm{dL}$ nos níveis de colesterol durante a internação diminuem a chance se sepse grave em 3\% (Grion et al., 2010).

Pessoas com níveis altos de HDL geneticamente determinados têm menor produção de mediadores inflamatórios quanto submetidos à infusão de endotoxina bacteriana (Birjmohun et al., 2007).

Além da função relacionada a processos inflamatórios a HDL tem papel fundamental na prevenção dos processos aterogênicos e seu efeito terapêutico tem sido cada vez mais estudado (Toth et al., 2013).

\subsection{Aterogenese e Alterações Lipídicas}

A aterogênese é uma doença inflamatória crônica de origem multifatorial e o metabolismo lipídico está intimamente relacionado com estados inflamatórios. A agressão ao endotélio vascular devido à elevação de lipoproteínas VLDL e LDL, hipertensão arterial, tabagismo e hiperglicemia levam ao aumento da permeabilidade da intima dos vasos, com consequente retenção de lipídios no espaço subendotelial. A LDL sofre oxidação estimulando o surgimento de moléculas de adesão leucocitária na superfície endotelial. Monócitos e linfócitos são aderidos à parede endotelial, migram para o espaço subendotelial onde captam a LDL oxidada. Os 
mediadores pró-inflamatórios estimulam a proliferação e migração de células musculares lisas da camada média para a íntima onde contribuem para a formação da capa fibrosa da placa aterosclerótica (Figura 2). A ruptura desta capa expõe material lipídico altamente trombogênico o que pode levar à formação de trombo sobrejacente (Sposito et al., 2007).

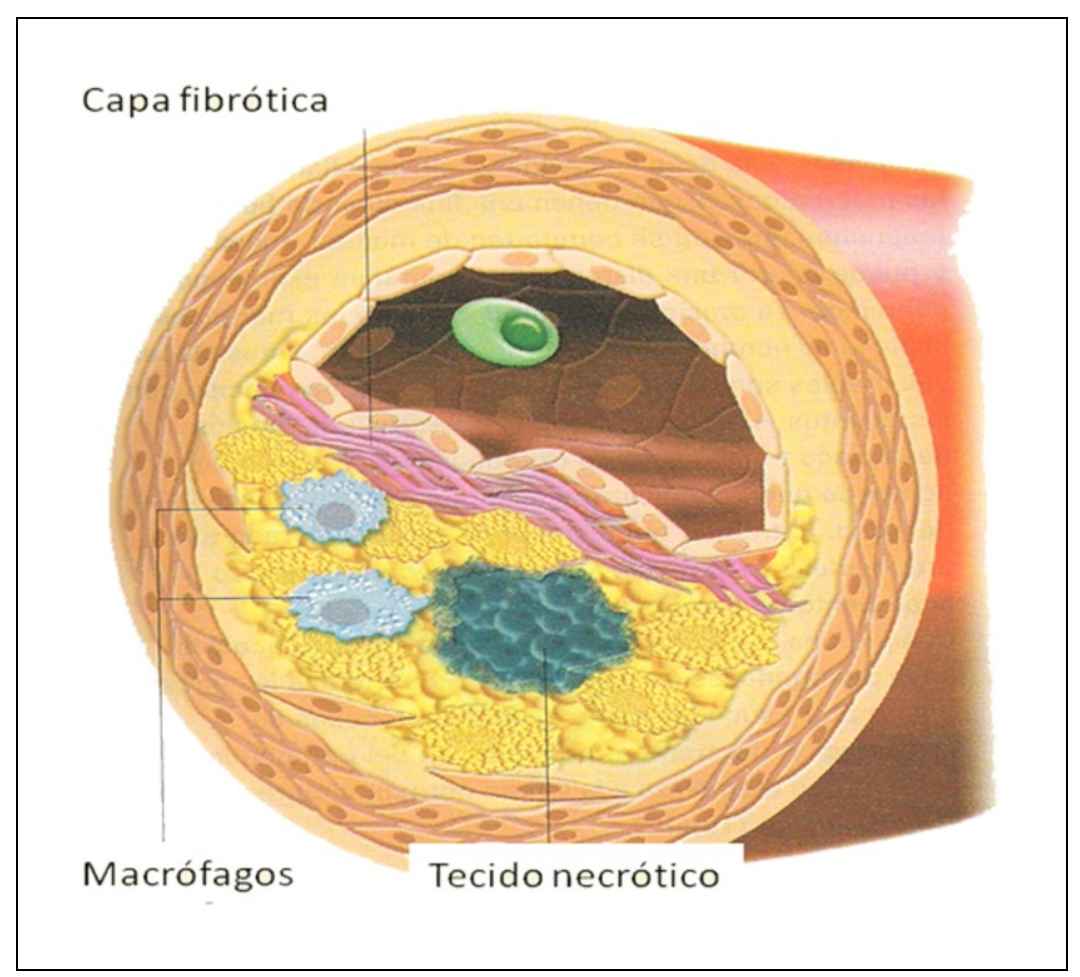

Figura 2 - Representação esquemática da placa aterosclerótica em vaso sanguíneo arterial [Fonte: Lépori (2003)]

A inflamação no endotélio pode ser detectada através da PCR, que é também um marcador de risco para doenças cardiovasculares. A dosagem da PCR ultrassensível (PCRus) é utilizada detecção de risco precoce para prevenção de doenças coronarianas. O papel na patogênese da aterosclerose ainda esta em estudo, porém sabe-se que a PCR se liga a fosfocolina de LDL oxidada, regula a expressão de moléculas de adesão endoteliais, aumenta a absorção de IDL em macrófagos, inibe a síntese 
endotelial de oxido nítrico nas células endoteliais da aorta e aumenta a expressão e atividade do inibidor-1 do ativador do plasminogênio (Jialal et al., 2004).

Pacientes obesos e dislipidêmicos são considerados pacientes com algum grau de inflamação detectável através de PCRus. Assim como ocorre em adultos obesos, crianças e adolescentes obesos (Z-escore para o índice de massa corpórea [IMC] maior que 2), também tem aumento de PCRus e interleucina-6 circulantes, o que demonstra um estado inflamatório que pode ser predisponente a doenças cardiocirculatórias, principalmente se esta condição se perpetuar até a vida adulta. A associação com síndrome metabólica agrava ainda mais este risco (Weiss et al., 2004).

Adolescentes com síndrome metabólica têm 3,4 vezes mais risco de desenvolver aterosclerose na idade adulta do que aqueles sem síndrome metabólica. No entanto, se tratados precocemente voltam a ter os mesmos riscos da população normal (Magnussen et al., 2012). A hipertensão arterial sistólica e níveis aumentados de LDL na infância são fatores predisponentes para o depósito de cálcio nas artérias na vida adulta independente dos outros fatores de risco (Hartiala et al., 2012).

O risco para desenvolvimento de doença coronariana (DAC) aumenta progressivamente a partir do aumento de CT e TG acima dos valores considerados limítrofes e da diminuição do HDL, mas principalmente se estas duas alterações estiverem presentes. Além das alterações do perfil lipídico, outros fatores de risco para DAC são: sexo masculino, hipertensão arterial, tabagismo, obesidade grave, doença cerebrovascular ou doença 
arterial periférica, diabetes melitus, historia familiar de DAC prematura (abaixo de 55 anos de idade em parentes de primeiro grau) e sedentarismo (Back et al., 2005).

Os estudos Muscatine e Bogalusa, importantes estudos de Coorte iniciados na década de 70, demonstraram que a dislipidemia e hipertensão arterial na infância predispõem ao desenvolvimento de espessamento da camada intima das artérias na vida adulta (Schrott et al., 1979 e 1982) e que alterações ateroscleróticas estão presentes nas artérias de jovens assintomáticos, principalmente naqueles com obesidade, hipertensão arterial e dislipidemia (Berenson et al., 1998). Uma avaliação destes estudos sugere que a idade de maior risco para o desenvolvimento de DAC na vida adulta, quando da exposição aos fatores de risco, é a partir de nove anos de idade (Juonala et al., 2010).

Crianças com sobrepeso e obesidade têm maior chance de se tornarem adultos obesos e com maior chance também de apresentarem todas as comorbidades relacionadas como diabetes tipo 2, hipertensão arterial, dislipidemia e aterosclerose. Crianças com sobrepeso e obesas que não desenvolveram obesidade na vida adulta apresentam os mesmos riscos da população eutrófica, ressaltando a importância do tratamento o quanto antes da obesidade na infância (Juonala et al., 2011). 


\subsection{Alterações Lipídicas e Estado Nutricional}

As hiperlipidemias são doenças caracterizadas pela excessiva produção ou diminuição do clearance de uma ou mais classes de lipoproteínas plasmáticas. As hiperlipidemias primárias, ou geneticamente determinadas, mais comumente encontradas na faixa etária pediátrica são as hipercolesterolemia familiar homo e heterozigótica, hipertrigliceridemia endógena, hiperquilomicronemia e hiperlipidemia combinada. Elas podem ser classificadas genotipicamente em monogênicas (alteração de um só gene) ou poligênicas (associação de múltiplas mutações). São causas de hiperlipidemia secundaria, em pediatria, o diabetes melitus, o hipotireoidismo, a síndrome nefrótica, e secundaria ao uso de medicamentos como isotretinoina (Romaldini, 2010).

Na classificação fenotípica ou bioquímica, que leva em consideração os níveis circulantes de CT, LDL, HDL e TG, as dislipidemias podem ser de quatro tipos:

- Hipercolesterolemia isolada: elevação isolada de LDL.

- Hipertrigliceridemia isolada: elevação isolada de TG.

- Hiperlipidemia mista: elevação de LDL e TG.

- HDL baixo: diminuição do HDL associado ou não a elevação de LDL e TG (Xavier et al., 2013).

Os valores dos lipídios séricos considerados normais, segundo as diretrizes da Sociedade Brasileira de Cardiologia (SBC) para crianças de dois a 19 anos de idade, estão descritos no Quadro 1 (Xavier et al., 2013). 
Quadro 1 - Valores de referência dosagem de lipídios em crianças de 2 a 19 anos de idade segundo a Sociedade Brasileira de Cardiologia

\begin{tabular}{|l|c|c|c|}
\hline \multicolumn{1}{|c|}{ Lipídios } & $\begin{array}{c}\text { Desejáveis } \\
(\mathbf{m g} / \mathbf{d L})\end{array}$ & $\begin{array}{c}\text { Limítrofes } \\
\text { (mg/dL) }\end{array}$ & $\begin{array}{c}\text { Aumentados } \\
\text { (mg/dL) }\end{array}$ \\
\hline CT & $<150$ & $150-169$ & $\geq 170$ \\
LDL & $<100$ & $100-129$ & $\geq 130$ \\
HDL & $\geq 45$ & & $\geq 130$ \\
TG & $<100$ & $100-129$ & $\geq$ \\
\hline
\end{tabular}

CT: colesterol total; LDL: lipoproteína de baixa densidade; HDL: lipoproteína de alta densidade: TG: triglicérides.

No Brasil a prevalência de dislipidemia está entre 28 e $40 \%$ das crianças e adolescentes segundo alguns estudos realizados em diferentes regiões do país (Moura et al., 2000; Dalpino et al., 2006; de Alcântara Neto et al., 2012). Estes valores estão subestimados se considerarmos que atualmente o valor de CT desejável abaixo de $150 \mathrm{mg} / \mathrm{dL}$ segundo a $\mathrm{V}$ diretriz publicada em 2014. Crianças obesas apresentam maior risco para dislipidemia e hipertensão arterial (Gama et al., 2007; Pereira et al., 2009).

Segundo a Organização Mundial da Saúde (OMS) nos últimos 10 anos houve uma diminuição da subnutrição brasileira e um aumento da obesidade infantil (OMS, 2014a), fator esse que contribui para um aumento da dislipidemia secundária. Segundo dados do Instituto Brasileiro de Geografia e Estatística (IBGE) o numero de crianças de cinco a nove anos de idade com sobrepeso aumentou de $15 \%$ para $34 \%$, o número de obesos aumentou de $4,1 \%$ para $16,6 \%$ em meninos e de 11,9 para $32 \%$ em meninas (SBP, 2008). Dados do National Health and Nutrition Examination Survey (NHANES), de 1999 a 2006, mostrou uma prevalência de dislipidemia em crianças nos Estados Unidos, com pelo menos uma das frações dosadas alteradas, em crianças de seis a 19 anos de idade, de 20,6\%. Crianças com 
sobrepeso e obesas mostraram serem 1,6 e três vezes mais propensos à dislipidemia, respectivamente (CDC, 2010). Entre 2007 e 2010 medidas de intervenção como dieta saudável, promoção da atividade física e diminuição do tabagismo, reduziram significativamente os níveis de colesterol para $10 \%$ e de hipertrigliceridemia de 11,3\% para 8,1 (Kit et al., 2012). A obesidade, dislipidemia e hipertensão arterial sistêmica na infância e adolescência são fatores de risco para o desenvolvimento do processo de aterogênese ( $\mathrm{Li}$ et al., 2003; Berenson et al., 1998; Morrison et al., 2012; Raitakari, 2014).

As recomendações da SBC para dosagem de lipídios séricos com finalidade de triagem de risco para crianças e adolescentes estão descritas no Quadro 2.

\section{Quadro 2 - Recomendação da SBC para dosagem de lipídios em crianças e adolescentes de 2 a 19 anos de idade}

\begin{tabular}{|l|l|}
\hline $\begin{array}{l}\text { Familiares } \\
\text { Manifestação }\end{array}$ & $\begin{array}{l}\text { Pai, mãe, avós, primos de primeiro grau com história de } \\
\text { dislipidemia, aterosclerose } \\
\text { Dislipidemia }\end{array}$ \\
$\begin{array}{l}\text { Outros fatores de } \\
\text { risco }\end{array}$ & $\begin{array}{l}\text { Tabagismo, hipertensão arterial } \\
\text { Hoenças }\end{array}$ \\
$\begin{array}{l}\text { Em uso de } \\
\text { medicamento }\end{array}$ & $\begin{array}{l}\text { Anticonceptivo oral, imunossupressores, corticoides, } \\
\text { antirretrovirais e outras drogas que possam elevar o colesterol } \\
\text { sérico }\end{array}$ \\
\hline
\end{tabular}

Quanto ao tratamento da dislipidemia em pediatria recomenda-se que aos dois anos devem-se iniciar medidas não farmacológicas como alteração dos hábitos alimentares, atividade física, e eliminar fatores de risco, acompanhado por médico e nutricionista. Após os 10 anos quando necessário iniciar tratamento farmacológico. Para os hipercolesterolêmicos 
homozigotos ou heterozigotos graves que poucos respondem a dieta alimentar, considerar iniciar tratamento farmacológico antes dos 10 anos de idade. Nos casos de hiperquilomicronemia grave indica-se restrição grave da oferta de gordura, mesmo antes de dois anos de idade, devido ao risco alto de desenvolver pancreatite. No caso de hipertrigliceridemia endógena devese restringir a oferta de carboidrato na dieta.

Segundo a SBC o tratamento farmacológico está indicado quando os valores de LDL estiverem maiores que $190 \mathrm{mg} / \mathrm{dL}$; ou maiores que 160 $\mathrm{mg} / \mathrm{dL}$ quando há dois ou mais fatores de risco, ou historia familiar, ou aterosclerose prematura; ou maiores que $130 \mathrm{mg} / \mathrm{dL}$ nos raros casos de comprometimento aterosclerótico (Quadro 2).

As resinas constituem a primeira escolha não devendo ser administradas na forma homozigótica. As estatinas podem ser utilizadas na forma mais grave. Os fármacos dever ser iniciados na menor dose indicada e a dose ser aumentada progressivamente. Exames clínicos e laboratoriais de controle devem ser adotados para eventuais efeitos adversos (Xavier et al., 2013).

As estatinas alem de reduzirem o CT, LDL nesta faixa etária também promovem melhora da função endotelial e diminuição da espessura intimamedia da carótida e regressão de xantomas. Para hipertrigliceridemia endógena quando as respostas à intervenção não farmacológicas não forem satisfatória, fibratos e AG Ômega 3 podem ser administrados, porém a experiência é pequena. Outras medidas para dislipidemia graves podem ser plasmaferese ou LDL aférese (Xavier et al., 2013). 


\section{Quadro 3 - Fármacos utilizados no tratamento das dislipidemias na criança e adolescentes}

\begin{tabular}{|c|c|}
\hline RESINAS & $\begin{array}{ll}\text { - } & \text { Constituem a primeira escolha } \\
\text { - } & \text { Não devem ser administradas na forma homozigótica } \\
\text { - } & \text { Iniciar na menor dose indicada e a dose ser aumentada } \\
\text { progressivamente } \\
\text { - } \quad \text { Exames clínicos e laboratoriais de controle devem ser adotados para } \\
\text { eventuais efeitos adversos }\end{array}$ \\
\hline ESTATINAS & $\begin{array}{l}\text { - } \quad \text { Iniciar nas formas mais graves } \\
\text { - } \quad \text { Reduzem o CT, LDL e também promovem melhora da função } \\
\text { endotelial, diminuição da espessura intima-media da carótida e } \\
\text { regressão de xantomas }\end{array}$ \\
\hline FIBRATOS & $\begin{array}{l}\text { - Para hipertrigliceridemia endógena quando as respostas à } \\
\text { intervenção não farmacológicas não forem satisfatória } \\
\text { - } \quad \text { Considerar associação com Ômega } 3\end{array}$ \\
\hline
\end{tabular}

Nos casos de dislipidemia secundaria a causa de base deve sempre ser tratada e os medicamentos potencialmente indutores de alterações e retirados ou substituídos (Xavier et al., 2013).

\subsection{Justificativa}

Considerando a possibilidade significativa de mudança no perfil lipídico, na instalação da doença inflamatória, associada ou não à infecção, com risco de desenvolvimento de aterogênese a médio e longo prazo, tornase relevante o estudo comparativo da avaliação das concentrações dos principais indicadores lipídicos em crianças e adolescentes com e sem processo inflamatório. 


\subsection{Hipótese}

Existem diferenças nas concentrações dos principais indicadores do perfil lipídico de crianças e adolescentes, com processo inflamatório, mesmo de menor intensidade e que potencialmente podem ter repercussão em processos de aterogênese futura. 


\section{Objetivos}




\subsection{Principal}

Comparar o perfil lipídico, com a dosagem de colesterol total, HDL, LDL e triglicérides, em crianças e adolescentes, com e sem inflamação, que procuraram atendimento num pronto socorro geral de pediatria de um hospital universitário de nível de atendimento secundário.

\subsection{Secundário}

- Comparar os resultados do perfil lipídico com a classificação nutricional realizada pelo Z-escore, segundo os critérios antropométricos principais: peso, estatura e idade.

- Avaliar associação da intensidade da resposta inflamatória e alterações do perfil lipídico. 


\section{MÉtodos}




\subsection{População}

Este estudo foi realizado em lactentes, crianças e adolescentes atendidos no serviço de emergência de um hospital universitário de nível de atendimento secundário. Este pronto atendimento funciona 24 horas e atende uma média de 188 pacientes (lactentes, crianças e adolescentes até 15 anos incompletos) por dia. Caracteriza-se por um hospital geral que presta atendimento a comunidade, alunos e funcionários da universidade através de atendimento de emergência clínico/cirúrgico e ambulatorial. Possui capacidade para 234 leitos de internação distribuídos em pediátricos, clínicos, cirúrgicos, maternidade, unidade de terapia intensiva adulto, pediátrica e neonatal. Realiza exames laboratoriais e de imagem na própria unidade hospitalar.

\subsection{Desenho do Estudo}

Este é um estudo transversal, em que foi analisado o perfil lipídico de pacientes com queixas relacionadas à infecção/inflamação, avaliando-se concomitantemente as variáveis adicionais como: estado nutricional, idade, gênero, concentrações de albumina e glicemia. A coleta de dados foi realizada entre outubro de 2012 a agosto de 2013 . 
Critérios de inclusão: foram incluídos pacientes de três meses a quinze anos de idade incompletos, atendidos no pronto atendimento, com e sem diagnostico presumido de processo inflamatório (principalmente de causa infecciosa).

Critérios de exclusão: foram excluídos pacientes com historia de doença hepática, dislipidemia, de diabetes melitus, erros inatos de metabolismo, com relato de uso de altas doses de corticosteroides (mais de $1 \mathrm{mg} / \mathrm{kg} / \mathrm{dia}$ de dose equivalente de prednisona, por mais de $10 \mathrm{dias}$ ) ou aqueles cujos responsáveis não aceitaram o termo de consentimento livre e esclarecido (TCLE) (Anexo A).

Este trabalho foi aprovado como projeto de pesquisa com o protocolo número 0334/11 pela Comissão de Ética para Análise de projetos de Pesquisa (CAPPesq) (Anexo B)

Os pacientes foram separados em dois grupos para análise de acordo com os valores da PCR, que é um importante marcador inflamatório. Consideramos os valores abaixo de $5 \mathrm{mg} / \mathrm{L}$ como normais de acordo com os valores de referência estabelecidos para pacientes saudáveis e não gestantes (Dati et al., 1996). Denominamos grupo I ou de pacientes "inflamados", o grupo cuja PCR resultou maior ou igual a 5 mg/L, e grupo II ou de pacientes "não-inflamados", o grupo cuja PCR resultou menor que 5 mg/L (Anexos C e D).

Durante o atendimento no pronto socorro realizamos para cada paciente uma dosagem de colesterol total (CT), HDL, LDL, TG, PCR, proteínas totais/frações e glicemia por fita. O material biológico foi 
processado pelo laboratório do Hospital Universitário da Universidade de São Paulo (HU-USP), com a utilização das seguintes metodologias: colesterol oxidase automatizado para $\mathrm{CT}$, direto automatizado para $\mathrm{HDL}$, cálculo Friedewald para LDL, glicerol peroxidase automatizado para TG, biureto automatizado para proteínas totais, VBC (verde de bromocresol) automatizado para albumina (ALB) e nefelometria para PCR (CardioPhase ${ }^{\circledR}$ hsCRP da Siemens Healthcare Diagnostics). A glicemia por fita reagente foi aferida pelo aparelho Accu-Che ${ }^{\circledR}$.

Os resultados dos exames laboratoriais e a classificação do estado nutricional foram comparados entre os grupos I e II. Também foram analisadas diferenças quanto à idade e sexo.

A interpretação dos resultados do perfil lipídico dos pacientes foi baseada nas recomendações da $\mathrm{V}$ Diretriz Brasileira de Dislipidemias e Prevenção da Aterosclerose da Sociedade Brasileira de Cardiologia (Xavier et al., 2013) e do Expert Panel on Integrated Guidelines for Cardiovascular Health and Risk Reduction in Children and Adolescents (NHLBI, 2014). Foram considerados normais os resultados das dosagens dos lipídios que estiveram dentro dos valores desejáveis: CT $<150 \mathrm{mg} / \mathrm{dL}$, $\mathrm{LDL}<100 \mathrm{mg} / \mathrm{dL}$, TG $<100 \mathrm{mg} / \mathrm{dL}$ e $\mathrm{HDL} \geq 45 \mathrm{mg} / \mathrm{dL}$ para os pacientes de todas as faixas etárias. Os valores limítrofes e aumentados foram considerados alterados.

Quanto à avaliação nutricional os pacientes foram classificados de acordo com as medidas antropométricas de peso, estatura, IMC e do Z-escore. A classificação nutricional do paciente foi determinada de acordo com as curvas de crescimento da Organização Mundial da Saúde (OMS, 2012 e 2014b). 
Foram agrupados para análise estatística em três grupos de acordo com o valor do Z-escore: eutróficos ( $\geq-2$ a $\leq 1)$, sobrepeso/obesos $(>1)$ e magreza/magreza extrema (<-2). Para os menores de cinco anos incompletos os pacientes com risco para sobrepeso (o Z-escore $>1$ e $\leq 2$ ) foram considerados como eutróficos, sendo considerado sobrepeso/obesidade aqueles cujo valor do Z-escore foi $>2$, para esta faixa etária. Para facilitação e melhor precisão dos cálculos foi utilizado o programa WHO-AnthroPlus da OMS que é fornecido pelo site da OMS (OMS AnthroPlus, 2012).

A Figura 3 resume o desenho do estudo.

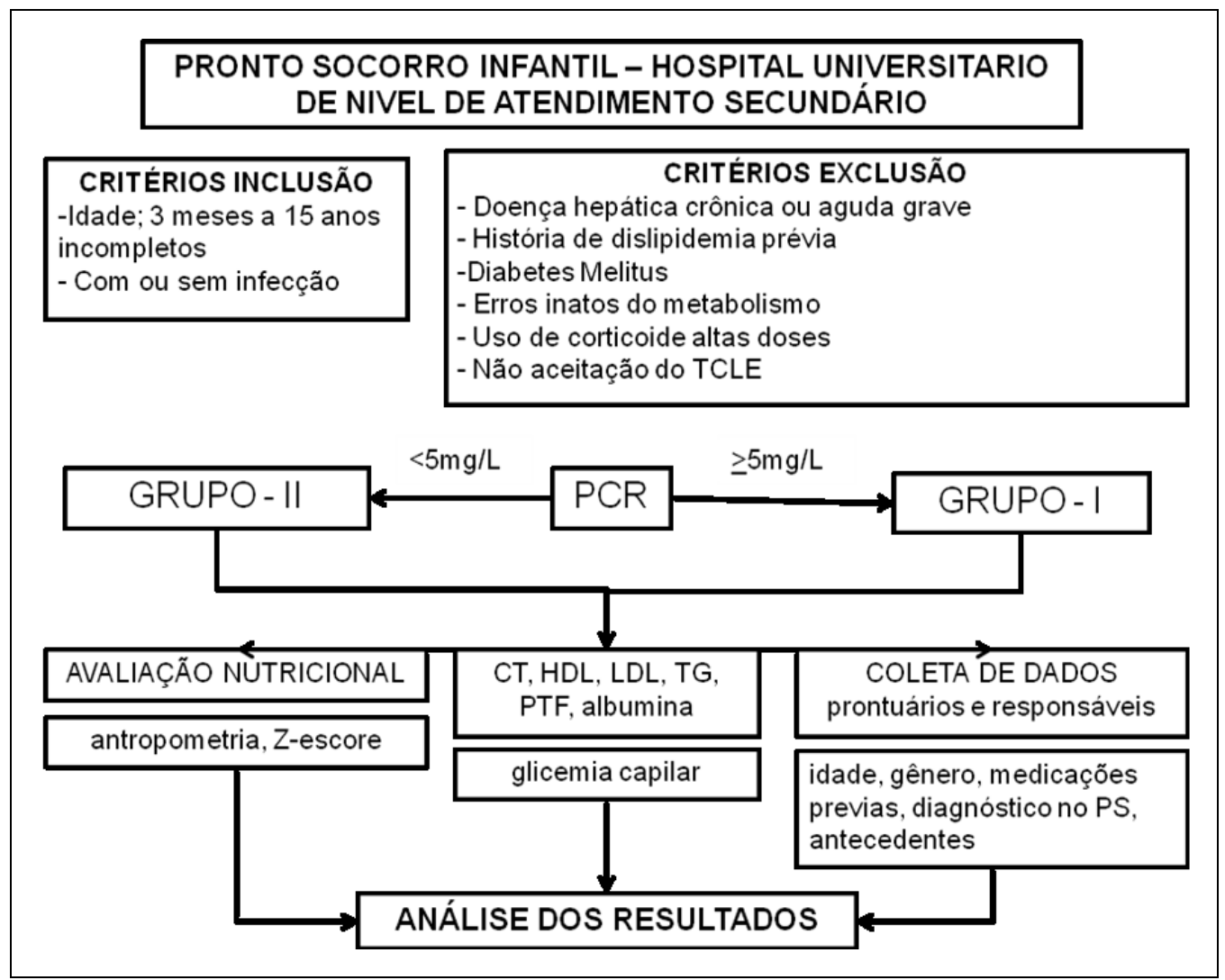

Figura 3 - Fluxograma do desenho do estudo 


\subsection{Cálculo da Amostra}

A amostra foi calculada visando encontrar diferença de pelo menos 10 mg/dL de HDL em crianças com e sem processo inflamatório, considerando a variabilidade da HDL de aproximadamente $15 \mathrm{mg} / \mathrm{dL}$, com intervalo de confiança de $95 \%$ e poder do teste de $80 \%$. Os testes foram realizados com nível de significância de 5\%.

\subsection{Análise Estatística}

As variáveis qualitativas e classificações do perfil lipídico foram descritas com o uso de frequências absolutas e relativas e as variáveis quantitativas com o uso de medias e desvio padrão (DP). As características pessoais, classificação do estado nutricional e caracterização do perfil lipídico foram descritas com o uso de medidas resumo (média, DP, mediana, mínimo e máximo) e comparadas entre os grupos I e II com uso do teste tStudent.

Para os pacientes com PCR $\geq 5 \mathrm{mg} / \mathrm{L}$ foi calculada a correlação de Spearman entre o perfil lipídico e as seguintes variáveis: PCR, estado nutricional, idade e gênero. Para aquelas com correlação estatisticamente significante, foram ajustados os modelos de regressão linear, permanecendo nos modelos finais, apenas as variáveis com níveis descritivos inferiores a $5 \%(p<0,05)$. 


\subsection{Informações Adicionais}

Foi criada uma ficha individual para cada paciente para anotação das informações obtidas através de ficha de atendimento do pronto socorro e entrevista com os responsáveis: identificação, endereço, data de nascimento/idade, diagnostico no pronto socorro, doenças prévias, uso de medicações, anotação de resultado da glicemia por fita e dos dados antropométricos (Anexo E).

Os resultados dos exames laboratoriais e demais informações foram compilados numa planilha Excel ${ }^{\circledR}$ para análise estatística.

Os resultados dos exames laboratoriais foram postados via correio para o endereço referido pelos responsáveis ou entregues em mãos caso o paciente ainda estivesse internado ou retornasse para reavaliação médica. 
4 Resultados 
Foram considerados elegíveis 129 pacientes. Houve perda de dois pacientes (amostra insuficiente para dosagem do PCR) e, em três não foram realizadas as medidas antropométricas. Portanto, dos 129 pacientes, foram incluídos para análise um total de 124.

A análise geral da amostra revelou 60 crianças e adolescentes do sexo feminino $(48,5 \%)$ e 64 do sexo masculino $(51,5 \%)$. A mediana de idade dos pacientes incluídos no estudo foi de 51 meses, distribuídos da seguinte forma: $38(30,6 \%)$ lactentes (menores de dois anos), 31 (25\%) pré-escolares (de dois anos a menores de cinco anos) e 55 (44,4\%) escolares e adolescentes (de cinco anos a menores de 15 anos). Quanto ao estado nutricional, $76,5 \%$ dos pacientes foram classificados como eutróficos, $17 \%$ como sobrepeso ou obesos e 6,5\% como magreza ou magreza extrema.

Quanto às dosagens de lipídios, os resultados estavam dentro dos valores considerados desejáveis para $65,3 \%$ do $\mathrm{CT}, 81,5 \%$ para LDL, e 65,3\% para TG. Ou seja, encontramos alterações nos níveis de lipídios em $34,7 \%$ dos pacientes para CT, $18,5 \%$ para LDL e $34,7 \%$ para TG. Quanto às dosagens de HDL, a maioria dos pacientes (67\%) apresentou concentrações séricas abaixo dos valores considerados desejáveis. Os resultados laboratoriais estão expostos no Gráfico 1. Dos pacientes que apresentaram 
baixas dosagens de HDL, 44,6\% tinham alteração isolada desta lipoproteína. Nos demais observamos alteração associada em 39 (47\%) de TG, 17 (20,5\%) de CT e $12(14,5 \%)$ de LDL.

Gráfico 1 - Resultado dos principais indicadores do perfil lipídico (CT, LDL, TG, HDL) na amostra total

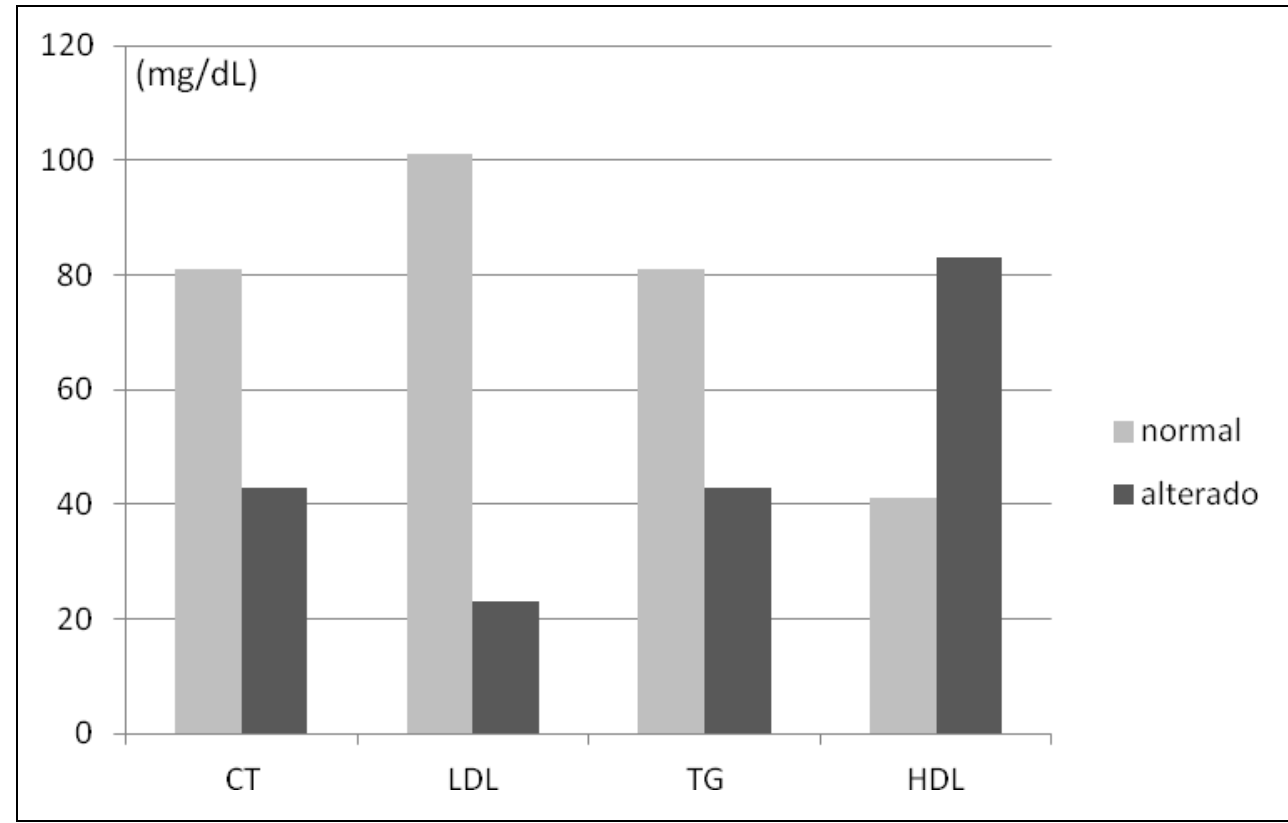

Observou-se que, nos três grupos da classificação nutricional, a maioria dos pacientes apresentava níveis baixos de HDL, ou seja, esta alteração ocorreu independente do estado nutricional (Tabela 1).

Tabela 1 - Estado nutricional e modificações nas concentrações dos lipídios séricos

\begin{tabular}{lcccc}
\hline \multirow{2}{*}{ Classificação nutricional } & \multicolumn{4}{c}{ Lipídios alterados } \\
\cline { 2 - 5 } & CT(\%) & LDL (\%) & TG (\%) & HDL (\%) \\
\hline Eutrófico & 39,5 & 18,5 & 37,5 & 64,5 \\
Magreza/Magreza extrema & 14,5 & 14,5 & 28,5 & 71,5 \\
Sobrepeso/Obeso & 19 & 19 & 23 & 76
\end{tabular}


Dos pacientes com CT acima dos limites desejáveis, 79\% eram eutróficos e $21 \%$ tinham sobrepeso ou obesidade, não havendo crianças e adolescentes com estado de magreza ou magreza extrema. Dentre os pacientes que apresentaram dosagem de HDL abaixo do desejável, $76 \%$ eram eutróficos, $18 \%$ tinham sobrepeso ou obesidade, e $6 \%$ encontravam-se em estado de magreza ou magreza extrema (Tabela 2).

Tabela 2- Distribuição dos pacientes de acordo com estado nutricional e as concentrações de CT acima do desejável e HDL abaixo do desejável

\begin{tabular}{lccc}
\hline & \multicolumn{3}{c}{ Classificação Nutricional } \\
\cline { 2 - 4 } Lipídios & $\begin{array}{c}\text { Eutrófico } \\
(\%)\end{array}$ & $\begin{array}{c}\text { Sobrepeso/ } \\
\text { Obesidade } \\
(\%)\end{array}$ & $\begin{array}{c}\text { Magreza/ } \\
\text { Magreza } \\
\text { extrema (\%) }\end{array}$ \\
\hline CT acima do desejável & 80 & 20 & 0 \\
HDL abaixo do desejável & 76 & 18 & 6 \\
\hline
\end{tabular}

Analisando o estado nutricional de acordo com a faixa etária, observamos que dentro de cada grupo etário a maioria dos indivíduos eram eutróficos. No grupo escolares/adolescentes achamos, porém, 19 (34\%) pacientes com sobrepeso ou obesidade, muito superior em relação às crianças de menor idade (Tabela 3). Os escolares/ adolescentes foram responsáveis por $90,5 \%$ dos pacientes com sobrepeso ou obesidade da amostra. 
Tabela 3 - Estado nutricional em cada faixa etária na amostra total

\begin{tabular}{lccc}
\hline & \multicolumn{3}{c}{ Classificação Nutricional } \\
\cline { 2 - 4 } \multicolumn{1}{c}{ Faixa etária } & $\begin{array}{c}\text { Eutrófico } \\
\mathbf{( \% )}\end{array}$ & $\begin{array}{c}\text { Sobrepeso/ } \\
\text { Obesidade } \\
(\%)\end{array}$ & $\begin{array}{c}\text { Magreza/ } \\
\text { Magreza } \\
\text { extrema (\%) }\end{array}$ \\
\hline Lactentes & 94,7 & Zero & 5,3 \\
Pré-escolares & 90,3 & 6,5 & 3,2 \\
Escolares/Adolescentes & 58,2 & 34,5 & 7,3 \\
\hline
\end{tabular}

Quanto à distribuição do perfil lipídico em relação às diferentes faixas etárias observamos que os lactentes apresentaram uma maior porcentagem de pacientes com aumento de TG e baixo HDL em relação às crianças mais velhas (Tabela 4).

Tabela 4 - Faixa etária e modificações do perfil lipídico

\begin{tabular}{lcccc}
\hline \multirow{2}{*}{ Faixa Etária } & \multicolumn{4}{c}{ Lipídios alterados } \\
\cline { 2 - 5 } & $\mathbf{C T ( \% )}$ & LDL (\%) & TG (\%) & HDL (\%) \\
\hline Lactente & 10,5 & 15,8 & 68,4 & 89,5 \\
Pré-escolar & 6,5 & 16,1 & 19,4 & 58,1 \\
Escolar/ Adolescente & 10,9 & 21,8 & 18,2 & 56,4 \\
\hline
\end{tabular}

A média de glicemia capilar foi de $106,9 \mathrm{mg} / \mathrm{dL}(\mathrm{DP}=26,8)$, sendo $56 \mathrm{mg} / \mathrm{dL}$ o valor mínimo e $288 \mathrm{mg} / \mathrm{dL}$ o valor máximo. Do total de pacientes, 19 (15,3\%) apresentaram valores de glicemia capilar acima de 126 mg/dL em medida única.

Os principais diagnósticos presumidos e/ou confirmados dos pacientes durante o atendimento foram de pneumonia, dengue, febre sem sinais localizatórios, diarreia aguda, celulite, impetigo, apendicite aguda, infecção do trato urinário e pielonefrite. 
De acordo com os valores da PCR, 82 pacientes foram incluídos no grupo I (PCR $\geq 5 \mathrm{mg} / \mathrm{L})$ e 42 pacientes no grupo II (PCR $<5 \mathrm{mg} / \mathrm{L})$. Na comparação entre os dois grupos não houve diferença estatisticamente significante para as variáveis: idade, gênero, estado nutricional, albumina sérica e também do perfil lipídico (CT, HDL, LDL e TG). Apenas a glicemia capilar mostrou-se aumentada significativamente no grupo I em relação ao grupo II ( $p=0,01)$ (Tabela 5).

Tabela 5 - Resultado do teste t-Student na comparação entre os grupos I e II de acordo com as variáveis: idade, glicemia, estado nutricional, perfil lipídico e concentrações de albumina

\begin{tabular}{lccc}
\hline \multicolumn{1}{c}{ Variável } & $\begin{array}{c}\text { Grupo II } \\
\text { PCR }<\mathbf{5 m g / L}\end{array}$ & $\begin{array}{c}\text { Grupo I } \\
\text { PCR } \geq \mathbf{5 m g / L}\end{array}$ & $\mathbf{p}$ \\
\cline { 2 - 4 } & Média & Média & \\
\hline Idade (meses) & 71,47 & 56,42 & 0,107 \\
Glicemia (mg/dL) & 98,15 & 111,33 & $0,010^{*}$ \\
IMC (Z-escore) & 0,00 & 0,01 & 0,954 \\
CT (mg/dL) & 142,36 & 133,66 & 0,116 \\
LDL (mg/dL) & 82,19 & 74,29 & 0,087 \\
HDL (mg/dL) & 41,19 & 39,12 & 0,467 \\
TG (mg/dL) & 100,48 & 106,54 & 0,757 \\
ALB (g/dL) & 4,42 & 4,39 & 0,573 \\
\hline
\end{tabular}

*Resultados relacionados à variável glicemia

Foram analisados os pacientes do Grupo I, cujo valor da PCR foi maior ou igual a $5 \mathrm{mg} / \mathrm{L}$, e aplicada uma analise de regressão linear (correlação Spearman), onde cada variável foi relacionada separadamente à variável PCR. Neste grupo, a mediana dos resultados da PCR foi $40 \mathrm{mg} / \mathrm{L}$ (6 a $318 \mathrm{mg} / \mathrm{L})$. A PCR apresentou correlação inversa com HDL $[r=(-) 0,363$ e $p=0,001]$ (Gráfico 2), com LDL $[r=(-) 0,235$ e $p=0,034]$ e com albumina [ $r=(-) 0,308$ e $p=0,005]$. 
Ou seja, quanto maior o resultado das dosagens da PCR menor o resultado das dosagens da HDL, LDL e albumina. Para os TG foi evidenciada uma correlação direta estatisticamente significante $(r=0,426$ e p $>0,001)$ (Gráfico 3), ou seja, quanto maior o valor do PCR dosado, maior o valor do TG (Tabela 6).

Para a idade também foi demonstrada uma correlação inversa $[r=(-) 0,261$ e $p=0,018]$, ou seja, quanto maior o PCR menor a idade. Não houve correlação significante do Z-escore do IMC com nenhuma variável avaliada $(p>0,05)$.

Gráfico 2 - Regressão linear mostrando correlação entre as variáveis HDL e PCR

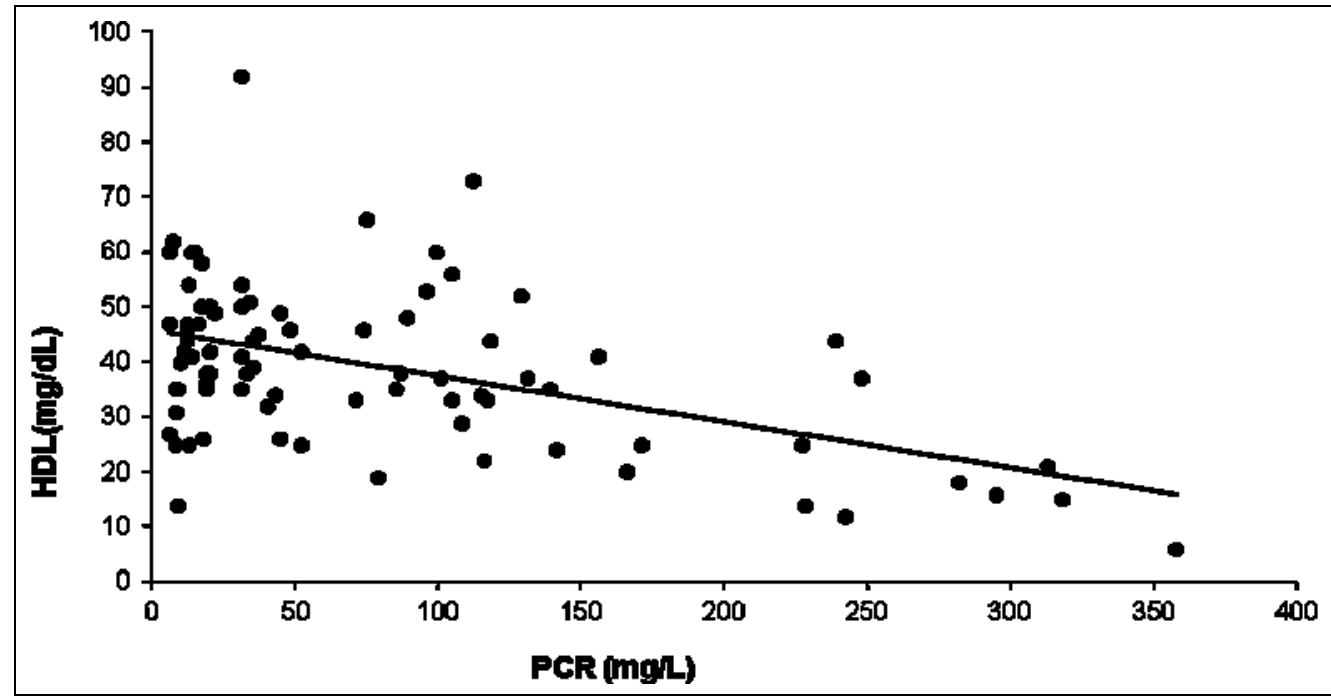


Gráfico 3 - Regressão linear mostrando correlação entre as variáveis TG e PCR

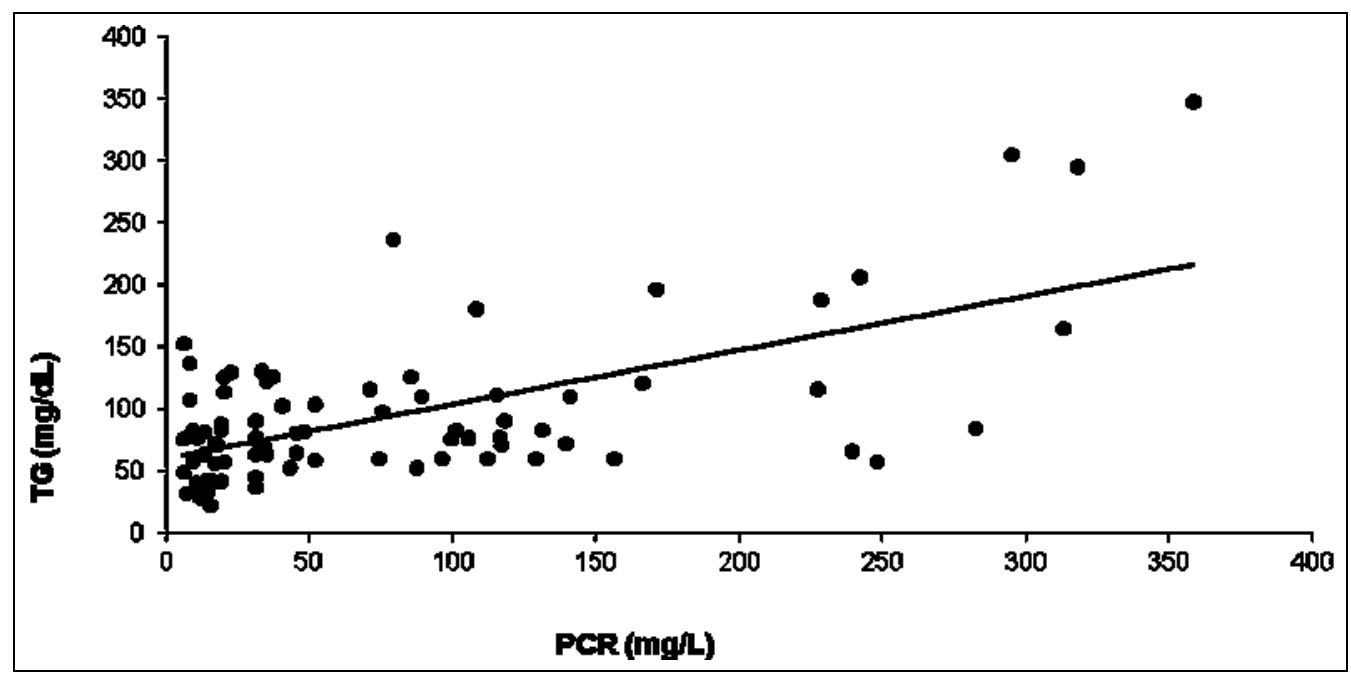

Tabela 6 - Resultado das correlações entre as variáveis analisadas nas crianças e adolescentes do Grupo I (PCR $\geq 5 \mathrm{mg} / \mathrm{L}$ )

\begin{tabular}{lcc}
\hline \multicolumn{1}{c}{ Variável } & \multicolumn{2}{c}{ Correlação } \\
\cline { 2 - 3 } Idade (meses) & $-0,261$ & $\mathbf{p}$ \\
Glicemia (mg/dL) & 0,050 & 0,018 \\
IMC (Z-escore) & 0,070 & 0,659 \\
CT (mg/dL) & $-0,175$ & 0,532 \\
LDL (mg/dL) & $-0,235$ & 0,116 \\
HDL (mg/dL) & $-0,363$ & 0,034 \\
TG (mg/dL) & 0,426 & 0,001 \\
ALB (g/dL) & $-0,308$ & $<0,001$ \\
\hline correlação direta. __ correlação inversa. & & 0,005 \\
\hline
\end{tabular}

Para os pacientes com algum grau de inflamação, ou seja, PCR maior ou igual a $5 \mathrm{mg} / \mathrm{L}$, podemos dizer que para cada aumento de $1 \mathrm{mg} / \mathrm{L}$ nos valores da PCR esperamos um aumento médio de 0,564 mg/dL do TG, uma redução média de 0,072 $\mathrm{mg} / \mathrm{dL}$ da $\mathrm{HDL}$, uma redução média de $0,083 \mathrm{mg} / \mathrm{dL}$ da LDL e uma redução média de $0,002 \mathrm{~g} / \mathrm{dL}$ de albumina, independente das demais características avaliadas neste grupo (Tabela 7). 
Tabela 7 - Resultado dos modelos de regressão das variáveis de perfil lipídico e concentrações de albumina segundo a variável PCR

\begin{tabular}{|c|c|c|c|c|c|c|}
\hline Variável & Fator & Estimativa & $\begin{array}{c}\text { Erro } \\
\text { padrão }\end{array}$ & Valor $\mathbf{t}$ & $\mathbf{p}$ & $\mathbf{R} 2$ \\
\hline \multirow{2}{*}{$\begin{array}{l}\text { LDL } \\
(\mathrm{mg} / \mathrm{dL})\end{array}$} & \multirow{2}{*}{$\begin{array}{c}\text { Constante } \\
\text { PCR } \\
\text { (mg/L) }\end{array}$} & 80,924 & 3,425 & 23,63 & $<0,001$ & \multirow{2}{*}{0,091} \\
\hline & & $-0,083$ & 0,029 & $-2,84$ & 0,006 & \\
\hline \multirow{3}{*}{$\begin{array}{l}\text { HDL } \\
(\mathrm{mg} / \mathrm{dL})\end{array}$} & Constante & 40,397 & 2,909 & 13,89 & $<0,001$ & \multirow{3}{*}{0,292} \\
\hline & $\begin{array}{l}\text { Idade } \\
\text { (meses) }\end{array}$ & 0,079 & 0,032 & 2,49 & 0,015 & \\
\hline & (mg/L) & $-0,072$ & 0,017 & $-4,21$ & $<0,001$ & \\
\hline \multirow{2}{*}{$\begin{array}{l}\text { TG } \\
(\mathrm{mg} / \mathrm{dL})\end{array}$} & Constante & 61,185 & 16,499 & 3,71 & $<0,001$ & \multirow{2}{*}{0,168} \\
\hline & (mg/L) & 0,564 & 0,140 & 4,03 & $<0,001$ & \\
\hline \multirow{2}{*}{$\begin{array}{l}\text { ALB } \\
(g / d L)\end{array}$} & \multirow{2}{*}{$\begin{array}{c}\text { Constante } \\
\text { PCR } \\
\text { (mg/L) }\end{array}$} & 4,547 & 0,048 & 95,37 & $<0,001$ & \multirow{2}{*}{0,231} \\
\hline & & $-0,002$ & 0,000 & $-4,90$ & $<0,001$ & \\
\hline
\end{tabular}




\section{Discussão}




\subsection{Características da Amostra}

$\mathrm{Na}$ análise da composição da amostra total vimos que não havia diferença quanto ao gênero. A maioria dos pacientes foi classificada nutricionalmente como eutrófica e as porcentagens de sobrepeso/obesidade $(17 \%)$ foram similares às encontradas em outros estudos que realizaram avaliação nutricional em crianças brasileiras. Recente revisão de literatura encontrou uma prevalência de sobrepeso/obesidade no Brasil com grandes variações, chegando a $28,8 \%$ de sobrepeso na região norte. Na região sudeste, região na qual realizamos o presente estudo, esta revisão mostrou uma prevalência de sobrepeso de até $17 \%$ e de obesidade de $15,4 \%$ (região com maior prevalência de obesidade do país) (Niehueset al., 2014). Ao analisar o perfil nutricional nas diferentes faixas etárias, observamos que 90,5\% dos indivíduos com sobrepeso/obesidade eram escolares e adolescentes. Dentre eles encontramos uma prevalência de $34,5 \%$ de sobrepeso/obesidade, pouco maior do que as encontradas em estudos que avaliaram o perfil nutricional na mesma faixa etária (Dalpino et al., 2006; Pereira et al., 2009; Mazaro et al., 2011; de Alcântara Neto et al., 2012). Crianças e adolescentes com sobrepeso e obesidade, muito provavelmente, se tornarão adultos também com sobrepeso e obesidade (Li et al., 2012). A obesidade está associada a um maior risco de desenvolvimento de 
complicações como diabetes tipo 2, dislipidemias, síndrome dos ovários policísticos, síndrome metabólica, dentre outros (Weiss et al., 2004; Irizarry et al., 2014). A associação de comorbidades, principalmente da síndrome metabólica, aumenta o risco de desenvolvimento de doença aterosclerótica dentre outras complicações na vida adulta (Magnussen et al., 2012).

Quanto ao perfil lipídico na amostra total encontramos que a maioria dos pacientes apresentaram também dosagens de CT, LDL e TG dentro dos valores considerados desejáveis. Porém achamos uma porcentagem de alterações acima do descrito na literatura, tanto para o CT $(34,7 \%)$ quanto para os TG $(34,7 \%)$. A porcentagem de alterações do CT foi similar ao encontrado no município de Campinas, no estado de São Paulo, em um estudo que avaliou 1600 escolares de 7 a 14 anos de idade e mostrou hipercolesterolemia em 35\% dos casos (Moura et al., 2000). Em 2001, na cidade de Florianópolis, em Santa Catarina, a avaliação de 1053 crianças entre sete e 18 anos de idade identificou uma porcentagem de alterações bem menor, $10 \%$ de hipercolesterolemia e $22 \%$ de hipertrigliceridemia (Giuliano et al., 2005). Nos Estados Unidos, dados do NHANES, de 1999 a 2006, mostraram uma prevalência de dislipidemia de 20,6\% em crianças de seis a 19 anos de idade, em pelo menos uma das frações dosadas. Crianças com sobrepeso e obesas evidenciaram ser 1,6 e três vezes mais propensas à dislipidemia, respectivamente (CDC, 2010). Estes dados, que já mostravam porcentagens de alterações menores do que encontramos e, em nova avaliação realizada entre 2007 e 2010, mostrou uma redução significativa dos níveis de colesterol para $10 \%$ das crianças de seis a 19 anos, 
e uma redução de hipertrigliceridemia de $11,3 \%$ para $8,1 \%$ atribuída a instituição de estratégias de prevenção na população americana (Kit et al., 2012). A alta prevalência de hipercolesterolemia encontrada é relevante, pois a presença e a persistência da mesma na adolescência levam ao espessamento da camada intima das artérias na idade adulta, caminho para instalação de doença aterosclerótica (Magnussen et al., 2009).

Sabemos que a obesidade e a alimentação inadequada estão associadas também à dislipidemia em crianças brasileiras (Ribas e Silva, 2009; de Alcântara Neto et al., 2012). No presente estudo, não evidenciamos, porém, associação entre resultados do perfil lipídico e o estado nutricional, sendo a porcentagem de pacientes com alterações no perfil lipídico similar entre os diferentes grupos de classificação nutricional. Uma diferença importante em relação aos referidos estudos que analisaram somente escolares e adolescentes, foi a inclusão de lactentes e pré-escolares (representaram 55,6\% da amostra total) no presente estudo. Observamos que as alterações de TG e HDL predominaram nos lactentes e pré-escolares, enquanto houve um predomínio de sobrepeso/obesidade nos escolares e adolescentes.

Outra diferença quanto à composição na amostra em relação a estes estudos epidemiológicos, foi em relação ao estado de saúde dos indivíduos estudados. A amostra do estudo em questão foi composta por pacientes doentes, com alguma queixa relacionada a processo inflamatório/infeccioso, em atendimento médico no setor de emergência, enquanto os demais analisaram crianças e adolescentes em ambiente escolar ou ambulatorial. A doença infecciosa, que cursa com estado inflamatório, pode alterar a 
concentração das lipoproteínas e TG na circulação, principalmente nos casos de inflamação sistêmica aguda grave, SIRS e sepse (van Leeuwen et al., 2003; Wilson et al., 2003; Vermont et al., 2005; Wendel et al., 2007; Vyroubal et al., 2008).

No presente estudo, observamos que os pacientes eutróficos representaram $80 \%$ e $76 \%$, dos pacientes com alteração do CT e HDL, respectivamente. Baseado no estado nutricional estes pacientes não teriam indicação de triagem para dislipidemia nesta faixa etária e estas alterações rotineiramente não seriam detectadas (SBP, 2008; Xavier et al., 2013).

\subsection{Analise das Diferenças entre Grupo I e II}

Na comparação entre os grupos I e || não foram evidenciadas alterações significativas entre a média das concentrações de CT, LDL, HDL e TG. Sabemos, no entanto, que infecções agudas leves também ocasionam redução dos níveis de $\mathrm{HDL}$ e LDL, como descrito em um estudo realizado em crianças e adolescentes eutróficos de nove a 21 anos de idade. Os autores compararam a HDL, LDL, CT e o estado inflamatório (PCR e orosomucoide) de indivíduos portando infecções leves com um grupo controle sem infecção. Foram comparados também com as dosagens do perfil lipídico, realizadas nos mesmos indivíduos três anos antes, porém sem dosagens das proteínas inflamatórias e sem informações sobre o estado de saúde na ocasião (Aburawi et al., 2006). Diferentemente do presente estudo, não houve inclusão de lactentes e pré-escolares bem como avaliação do estado nutricional dos indivíduos estudados. 
No presente estudo, houve um aumento significativo somente da glicemia no grupo I, que pode ser explicada pelas alterações hormonais que ocorrem durante a fase aguda do processo inflamatório. As alterações do nível glicêmico durante o processo inflamatório ocorrem independentes das alterações agudas do perfil lipídico durante a sepse (Cappi et al., 2012).

\subsection{Alteração das Concentrações dos Lipídios Durante a Inflamação e Suas Implicações}

No Grupo I, aqueles cujo PCR foi maior ou igual a $5 \mathrm{mg} / \mathrm{L}$, os pacientes tinham diagnóstico suspeitos de infecção na sua maioria. Níveis aumentados de PCR indicam um estado inflamatório inespecífico e seu nível dosado não determina a etiologia da inflamação, sendo importante o seu monitoramento no acompanhamento durante a terapia antimicrobiana em quadros infecciosos já diagnosticados (Jaye e Waites, 1997). Entretanto, sabemos que infecções bacterianas estão associadas á concentrações de PCR maiores do que $5 \mathrm{mg} / \mathrm{L}$ (Flanders et al., 2005). Na suspeita de pneumonia comunitária, particularmente, a PCR é um bom preditor de pneumonia bacteriana (Bafadhel et al., 2011), e concentrações muito elevadas (acima de $100 \mathrm{mg} / \mathrm{L}$ ) são consideradas como bom preditor de origem pneumococcica ou de infecções bacterianas sistêmicas mais graves (Galetto-Lacour et al., 2013; Nijman et al., 2013).

$\mathrm{Na}$ análise dos resultados do grupo I, evidenciamos correlação significativa dos níveis de lipídios com a intensidade da inflamação, mostrando que quanto maiores os valores de PCR, maiores os valores de 
TG e menores os valores de HDL, LDL e albumina esperados. Pacientes com sepse grave/choque séptico apresentam alterações importantes das concentrações dos lipídios circulantes, também com aumentos de TG e reduções da HDL e LDL, compatíveis com o intenso estado inflamatório (Alvarez e Ramos, 1986; Murch et al., 2006).

Em pediatria poucos são os estudos publicados relacionando infecção com alterações de lipoproteínas. O monitoramento do CT, HDL, LDL, interleucina-6 e do fator de necrose tumoral- $\alpha$ (TNF- $\alpha$ ) de crianças (mediana de 2,8 anos de idade) com sepse grave de origem meningococcica evidenciou que baixos níveis de HDL e LDL relacionaram-se com dosagens elevadas de interleucina-6 e uma maior pontuação no escore de gravidade PRISM. As baixas dosagens de CT se relacionaram significativamente com maior mortalidade. Os níveis das lipoproteínas neste estudo levaram cerca de um a três meses para se normalizarem (Vermont et al., 2005). Estudos em adultos que evidenciaram modificações nas concentrações das lipoproteínas relacionadas à SIRS e sepse observaram que elas já estão presentes na admissão e que levam até 28 dias para retornarem à níveis normais (Alvarez e Ramos, 1986; van Leeuwen et al. 2003; Chenaud et al., 2004).

A acentuada redução das lipoproteínas na fase aguda do processo inflamatório sistêmico grave, associada ao longo período para normalização das concentrações das mesmas, são relevantes quando lembramos que baixas concentrações séricas de HDL se correlacionam com risco aumentado de desenvolvimento de doença aterosclerótica e coronariopatia (Barter et al., 2007; de la Llera Moya et al., 2012). Somado a isso, durante processos 
infecciosos ocorrem alterações na função das lipoproteínas que contribuem para a patogênese da aterosclerose (Ravnskov e McCully, 2012). Os lipopolissacarides, endotoxinas presentes na parede celular de bactérias gram-negativas, se ligam às lipoproteínas na circulação durante processos infecciosos formando complexos que são em parte removidos pelo fígado. Os lipopolissacarides quando presentes se ligam preferencialmente às HDL que promovem sua neutralização. Durante a sepse, porém, os lipopolissacarides se ligam em maior quantidade as VLDL e LDL, cujos complexos formados são captados pelo fígado e também por macrófagos do endotélio, dando origem às células espumosas e ao processo aterogênico (Levels et al., 2003; Kallio et al., 2006; Lakio et al., e 2008).

Na presença de estado inflamatório de pequena intensidade já ocorrem alterações no perfil lipídico, que frequentemente estão presentes de forma mais intensa nos estados inflamatórios mais graves. Tal fenômeno se deve à ação dos mediadores químicos envolvidos nesta resposta e podem estar presentes precocemente nos pacientes com infecção, mesmo antes do desenvolvimento de sepse ou choque séptico. Alguns estudos sugerem que baixos níveis de colesterol podem ser um biomarcador para identificação precoce de pacientes com alto risco para o desenvolvimento de complicações infecciosas e sepse no pós-operatório de cirurgias eletivas, como cirurgia cardíaca. O monitoramento de CT, no pré e no pós-operatório de cirurgia cardíaca com circulação extracorpórea, em 270 adultos maiores de 18 anos, mostrou que baixos níveis de CT no pré-operatório se relacionaram com maiores concentrações de procalcitonina e o desenvolvimento de sepse nos 
primeiros quatro dias de pós-operatório (Lagrost et al, 2014). Pacientes adultos em pós-operatório de cirurgia gastrointestinal que apresentaram dosagens baixas de CT (< $160 \mathrm{mg} / \mathrm{dL}$ ) antes da admissão para cirurgia tiveram maior risco de desenvolverem complicações como infecção de ferida cirúrgica e pneumonia (Morimoto et al., 2010).

\subsection{Baixas Concentrações de HDL e a Aterogênese}

No presente estudo, uma característica muito importante evidenciada no perfil lipídico da amostra total foi que a maioria dos pacientes $(67 \%)$ apresentou dosagem de HDL abaixo do desejável. Este resultado difere de outros estudos realizados em crianças e adolescentes brasileiros que encontraram uma média de HDL dentro dos valores normais (Moura et al., 2000; Giuliano Ide et al., 2005). Diferente destes estudos em que as coletas foram realizadas principalmente em ambiente escolar (de normalidade), no presente estudo, os indivíduos estavam em atendimento no serviço de emergência com queixa relacionada à alguma condição inflamatória. As baixas concentrações de HDL predominaram entre os menores de cinco anos, mesmo assim detectamos que $56 \%$ dos escolares e adolescentes tinham níveis baixos de HDL. O fato dos pacientes, na sua maioria, estarem com algum processo inflamatório pode ser o principal fator que influenciou na alta prevalência de baixas concentrações de HDL na amostra. Principalmente nos lactentes, dentre os quais $89,5 \%$ apresentaram níveis reduzidos de HDL e também apresentaram elevadas concentrações de PCR em relação a outras faixas etárias. 
Considerando então que processos infecciosos agudos leves também podem levar a redução dos níveis de HDL (Aburawi et al., 2006), podemos explicar os baixos níveis desta lipoproteína pelo fato da amostra ser composta na sua maioria por pacientes com diagnósticos relacionados à infecção/inflamação. Estudo, realizado em crianças internadas com infecção aguda, demonstrou que a redução dos níveis de HDL nas primeiras 24 horas de infecção pode ter correlação positiva com o espessamento da camada íntima da artéria carótida à ultrassonografia quando comparadas a um grupo controle. Neste estudo o espessamento da artéria carótida foi maior naquelas que não receberam antibioticoterapia. Processos infecciosos/inflamatórios leves são comuns no decorrer da infância e adolescência e alteram o perfil lipídico com redução dos níveis de HDL provavelmente a cada episódio infeccioso, podendo trazer importantes repercussões na vida adulta, como desenvolvimento de doença aterosclerótica (Liuba et al., 2003).

A HDL é responsável pela esterificação e transporte reverso do colesterol (transporte do colesterol dos tecidos para o fígado) (Tall, 1990). Neste processo a HDL promove a remoção de lipídeos oxidados da LDL, a inibição da fixação de monócitos ao endotélio e estimulação da liberação de oxido nítrico (Rosenson et al., 2012). Durante a infecção aguda há um aumento dos mediadores inflamatórios e uma alteração do perfil lipídico próaterogênico que provoca disfunção endotelial transitória (Kilickap et al., 2011). Alterações da HDL na infância e adolescência podem estar associadas à menor proteção contra aterogênese, em pacientes com 
processo inflamatório persistente (Liuba et al., 2003). Independente do perfil lipídico de base, durante processos inflamatórios/ infecciosos ocorre alteração nas concentrações das lipoproteínas, na sua estrutura e função, que levam a um aumento do risco para aterogênese (Kallio et al., 2008; Matsuura et al., 2009; Wiesner et al., 2010; Ravnskov e McCully, 2012).

\subsection{Baixas Concentrações de HDL e Resposta Inflamatória}

A alta prevalência de níveis baixos de HDL encontrados no presente estudo, além de conferir menor proteção contra aterogênese, predispõem estes indivíduos a um potencial agravo frente a processos infecciosos mais importantes. A HDL tem importante papel protetor durante o processo infeccioso com funções na modulação da resposta inflamatória e neutralização de lipopolissacarides (Murch et al., 2006). Estudo em adultos internados demonstrou que para cada aumento de $1 \mathrm{mg} / \mathrm{dL}$ nos níveis de HDL durante a internação a chance de sepse grave diminui em 3\% (Grion et al., 2010). Níveis baixos de HDL em adultos com sepse foram associados com maior mortalidade e maior tempo de internação em UTI (Chien et al., 2005). Em estudo observacional que incluiu 1385 pacientes vitimas de acidente vascular cerebral, evidenciou um papel protetor da HDL contra o desenvolvimento de infecção hospitalar, principalmente em concentrações $\geq$ $35 \mathrm{mg} / \mathrm{dL}$ (Rodríguez et al., 2013). Em crianças com mediana de idade de quatro anos, submetidas à cirurgia cardíaca para correção de ventrículo único (cirurgia de Fontan), com necessidade de circulação extracorpórea, observou-se uma significativa redução das concentrações de HDL no pós- 
operatório, porém sem correlação significativa com o tempo de drenagem torácica ou a presença de derrame pleural quiloso $(p=0,09)$ (Zyblewski et al., 2012).

Estudos experimentais em humanos evidenciaram alterações lipídicas similares às descritas e um possível papel protetor da HDL frente à resposta inflamatória (Hudgins et al., 2003; Birjmohun et al., 2007). Em animais, pesquisas demonstraram o benefício de níveis mais altos de HDL e de apo Al (principal apoproteína ligada à HDL) na circulação e melhor resposta imunológica frente a quadros de infecção sistêmica grave. A administração de apo Al em animais com infecção grave reduziu a produção de mediadores inflamatórios e a mortalidade em alguns desses estudos (Imai et al., 2003; Jiao e Wu, 2008; Guo et al., 2013). 
6 ConClusões 
a. Não houve alteração significativa dos valores médios de CT, LDL, HDL e TG quando comparados os dois grupos de pacientes pediátricos atendidos no pronto socorro com e sem processo inflamatório.

b. Houve elevado percentual de pacientes $(34,7 \%)$ com alteração do CT e/ou TG.

c. As dosagens de HDL estavam abaixo dos valores desejáveis em $67 \%$ dos pacientes.

d. Não houve correlação entre as dosagens alteradas dos lipídios e distúrbios do estado nutricional, tanto para as alterações do CT, TG quanto da HDL.

e. Os níveis de lipídios se correlacionaram com a intensidade da inflamação, mostrando que quanto maior o valor da PCR mais elevadas as concentrações de TG e menores as de HDL e LDL.

f. Para cada aumento de $1 \mathrm{mg} / \mathrm{L}$ nas concentrações de PCR esperamos um aumento médio de $0,564 \mathrm{mg} / \mathrm{dL}$ do TG, uma redução média de $0,072 \mathrm{mg} / \mathrm{dL}$ da HDL e uma redução média de 0,083 mg/dL da LDL, independente do estado nutricional. 
7 ANEXos 


\section{Anexo A - Termo de Consentimento Livre e Esclarecido \\ HOSPITAL DAS CLÍNICAS DA FACULDADE DE MEDICINA DA UNIVERSIDADE DE SÃO PAULO-HCFMUSP e HOSPITAL UNIVERSITÁRIO DA UNIVERSIDADE DE SÃO PAULO}

TERMO DE CONSENTIMENTO LIVRE E ESCLARECIDO

DADOS DE IDENTIFICAÇÃO DO SUJEITO DA PESQUISA OU RESPONSÁVEL LEGAL

1. NOME:

DOCUMENTO DE IDENTIDADE N ${ }^{\circ}$

SEXO : $\quad M \square F \square$

DATA NASCIMENTO: ..../...............

ENDEREÇO $\mathrm{N}^{\mathrm{o}}$ APTO:

BAIRRO:

CEP: TELEFONE: DDD

CIDADE

2. RESPONSÁVEL LEGAL

NATUREZA (grau de parentesco, tutor, curador etc.)

DOCUMENTO DE IDENTIDADE :

DATA NASCIMENTO.: ....................

ENDEREÇO:

BAIRRO:

CEP:

SEXO: $M \square F \square$

$\mathrm{N}^{\circ}$

CIDADE:

TELEFONE: DDD ...)

\section{DADOS SOBRE A PESQUISA}

1. TÍTULO DO PROTOCOLO DE PESQUISA : Avaliação das concentrações de lipídios e apoproteínas à admissão em crianças e adolescentes gravemente doentes.

PESQUISADOR RESPONSÁVEL: .Artur Figueiredo Delgado.

CARGO/FUNÇÃO: medico coordenador da UTI do Instituto da criança

INSCRIÇÃO CONSELHO REGIONAL Nº 52090

UNIDADE DO HCFMUSP: Instituto da Criança

2. AVALIAÇÃO DO RISCO DA PESQUISA:

$\begin{array}{lll}\text { RISCO MÍNIMO } & \square X & \text { RISCO MÉDIO } \square \\ \text { RISCO BAIXO } & \square & \text { RISCO MAIOR } \square\end{array}$

3. DURAÇÃO DA PESQUISA: .1 ano 


\section{HOSPITAL DAS CLÍNICAS DA FACULDADE DE MEDICINA DA UNIVERSIDADE DE SÃO PAULO-HCFMUSP e HOSPITAL UNIVERSITÁRIO DA UNIVERSIDADE DE SÃO PAULO}

Este estudo tem como objetivo avaliar as concentrações de gorduras no sangue de crianças e adolescentes, com e sem infecção, atendidos no pronto socorro infantil do Hospital Universitário da Universidade de São Paulo.

Para tal serão coletadas amostras de sangue periférico durante $o$ atendimento do paciente no pronto socorro. Este material biológico será encaminhado para o laboratório para ser submetido às dosagens especificadas.

A coleta de até $5 \mathrm{ml}$ de sangue será realizada através da punção com agulha de veia do membro superior direito ou esquerdo, sendo necessário prévio garroteamento do antebraço. O procedimento de coleta de sangue pode gerar algum desconforto no momento da coleta. Não será indicada a sedação ou analgesia do paciente para tal procedimento. A amostra de sangue que será colocada em frasco adequado e identificado separadamente das amostras de sangue colhidas durante o atendimento do paciente. A coleta da amostra de sangue para a pesquisa poderá ser realizada no momento da coleta dos exames de rotina expondo o paciente a um mesmo procedimento de punção venosa, evitando assim um possível desconforto adicional.

Não há benefício direto para o participante deste estudo. Trata-se de um estudo que visa detectar as alterações nos níveis de gorduras e mediadores inflamatórios em pacientes pediátricos. Somente no final do estudo poderemos concluir a presença de algum benefício.

Em qualquer etapa do estudo você terá acesso aos profissionais responsáveis pela pesquisa para esclarecimento de eventuais dúvidas. O principal investigador é Dra Giovana Muramoto que pode ser encontrada no Pronto Socorro Infantil do Hospital Universitário da Universidade de São Paulo que fica no endereço: Av. Professor Lineu Prestes, 2565 - Butantã, Universidade de São Paulo, CEP 05508-000, São Paulo, SP, Telefone: (11) 3091-9200.

Se você tiver alguma consideração ou dúvida sobre a ética da pesquisa, entre em contato com o Comitê de Ética em Pesquisa (CEP-HU): Endereço: Av. Prof. Lineu Prestes, 2565 - Cidade Universitária - CEP: 05508-000 - São Paulo - SP - Telefone: 3091-9457 Fax: 3091-9452 - E-mail: cep@hu.usp.br.

É garantida a liberdade da retirada de consentimento a qualquer momento e deixar de participar do estudo, sem qualquer prejuízo à continuidade de seu tratamento na Instituição. 
As informações obtidas serão analisadas em conjunto com outros pacientes, não sendo divulgada a identificação de nenhum paciente. Você terá direito de ser mantido atualizado sobre os resultados parciais das pesquisas. Os dados e o material coletado somente para esta pesquisa.

Não há despesas pessoais para o participante em qualquer fase do estudo, incluindo exames e consultas. Também não há compensação financeira relacionada à sua participação. Se existir qualquer despesa adicional, ela será absorvida pelo orçamento da pesquisa. Os dados e o material coletado somente para esta pesquisa.

Acredito ter sido suficientemente informado a respeito das informações que li ou que foram lidas para mim, descrevendo o estudo "Avaliação das concentrações de lipídios e apoproteínas à admissão em crianças e adolescentes gravemente doentes".

Eu discuti com o Dra. Giovana Muramoto sobre a minha decisão em participar nesse estudo. Ficaram claros para mim quais são os propósitos do estudo, os procedimentos a serem realizados, seus desconfortos e riscos, as garantias de confidencialidade e de esclarecimentos permanentes. Ficou claro também que minha participação é isenta de despesas e que tenho garantia do acesso a tratamento hospitalar quando necessário. Concordo voluntariamente em participar deste estudo e poderei retirar o meu consentimento a qualquer momento, antes ou durante o mesmo, sem penalidades ou prejuízo ou perda de qualquer benefício que eu possa ter adquirido, ou no meu atendimento neste Serviço. Declaro que, após convenientemente esclarecido pelo pesquisador e ter entendido o que me foi explicado, consinto em participar do presente Projeto de Pesquisa.

Assinatura do paciente / representante legal Data

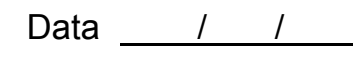

Assinatura da testemunha

(para casos de pacientes menores de 18 anos, analfabetos, semi-analfabetos ou portadores de deficiência auditiva ou visual)

\section{(Somente para o responsável do projeto)}

Declaro que obtive de forma apropriada e voluntária o Consentimento Livre e Esclarecido deste paciente ou representante legal para a participação neste estudo. 


\section{Anexo B - Aprovação CAPPesq}

\section{Hospital das Clínicas da FMUSP}

Comissão de Ética para Análise de Projetos de Pesquisa - CAPPesq

\section{PROJETO DE PESQUISA}

Título: AVALIAÇÃO DAS CONCENTRAÇÕES DE LIPÍDIOS E APOPROTEÍNAS À ADMISSÃO EM CRIANÇAS E ADOLESCENTES GRAVEMENTE DOENTES

Pesquisador Responsável: ARTUR FIGUEIREDO DELGADO

Versão: 1

Pesquisador Executante: Giovana Muramoto

CAAE: 13819213.0 .0000 .0068

Finalidade Acadêmica Mestrado

Instituição: HCFMUSP

Departamento: PEDIATRIA

\section{PARECER CONSUBSTANCIADO DO CEP}

Registro on-line: 7363

Número do Parecer: 208.888

Data da Relatoria: 01/03/2013 Ad-referendum

Apresentação do Projeto: 0 projeto está corretamente redigido e aborda tema atual

Objetivo da Pesquisa: Visa documentar lipídios e apoproteinas em crianças graves com e sem sepse, internadas em UTI

Avaliação dos Riscos e Benefícios: Os riscos se limitam à coleta de sangue. Poderá haver beneficios na medida em que o prognóstico destes pacientes se aprimorar.

Comentários e Considerações sobre a Pesquisa: A equipe é experiente e o estudo poderá trazer subsidios úteis

Consideraçães sobre os Termos de apresentação obrigatória: O TCLE é aceitável. Vale a pena enfatizar que conforme as normas da CAPPesq ele deve ser assinado por ambos os pais. Se a criança possuir discernimento e estiver em condições fisicas de participar, deverá assinar também.

Recomendações: Recomenda-se atentar para a recomendação do item anterior

Conclusões ou Pendências e Lista de Inadequaç̃̃es: Não há pendências

Situaç̃o do Parecer: Aprovado

Necessita Apreciação da CONEP: Não

Considerações Finais a critério do CEP: Em conformidade com o item IX.2 da Resolução CNS no 196/96 cabe ao pesquisador: a) desenvolver o projeto conforme delineado; b) elaborar e apresentar relatórios parciais e final; c)apresentar dados solicitados pelo CEP, a qualquer momento; d) manter em arquivo sob sua guarda, por 5 anos da pesquisa, contendo fichas individuais e todos os demais documentos recomendados pelo CEP; e) encaminhar os resultados para publicação, com os devidos créditos aos pesquisadores associados e ao pessoal técnico participante do projeto; f) justificar perante ao CEP interrupção do projeto ou a não publicação dos resultados.

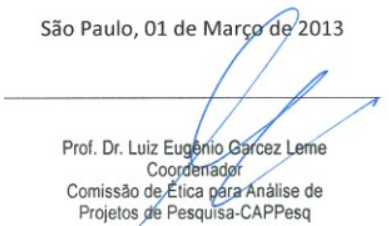

Rua Dr. Ovídio Pires de Campos, 225 - Prédio da Administração - 50 andar CEP 05403-010 - São Paulo - SP.tnb

5511 2661-7585 - 5511 2661-6442 ramais: 16, 17, 18 | marcia.carvalho@hc.fm.usp.br 


\section{Anexo C - Planilha de dados referente ao Grupo I}

\begin{tabular}{|c|c|c|c|c|c|c|c|c|c|}
\hline Sexo & $\begin{array}{c}\text { Idade } \\
\text { (meses) }\end{array}$ & $\begin{array}{c}\text { IMC: } \\
\text { z-escore }\end{array}$ & $\begin{array}{c}\text { PCR } \\
\text { (mg/L) }\end{array}$ & $\begin{array}{c}\mathrm{CT} \\
(\mathrm{mg} / \mathrm{dL})\end{array}$ & $\begin{array}{c}\mathrm{LDL} \\
(\mathrm{mg} / \mathrm{dL})\end{array}$ & $\begin{array}{c}\mathrm{HDL} \\
(\mathrm{mg} / \mathrm{dL})\end{array}$ & $\begin{array}{c}\text { TG } \\
(\mathrm{mg} / \mathrm{dL})\end{array}$ & $\begin{array}{c}\text { ALB } \\
\text { (g/dL) }\end{array}$ & DEXTRO \\
\hline$M$ & 4,10 & $-0,24$ & 9 & 116 & 64 & 35 & 84 & 4,7 & 288 \\
\hline$M$ & 4,83 & $-0,12$ & 52 & 91 & 45 & 25 & 104 & 4,6 & 107 \\
\hline$M$ & 5,63 & $-0,13$ & 33 & 138 & 74 & 38 & 131 & 5 & 114 \\
\hline $\mathrm{F}$ & 6,00 & 0,54 & 6 & 143 & 85 & 27 & 153 & 4,4 & 89 \\
\hline $\mathrm{F}$ & 6,70 & $-1,6$ & 171 & 113 & 61 & 25 & 197 & 4,4 & 123 \\
\hline $\mathrm{F}$ & 7,30 & 0,1 & 115 & 132 & 76 & 34 & 112 & 4,4 & 90 \\
\hline$F$ & 7,60 & $-0,46$ & 31 & 115 & 64 & 35 & 78 & 4,2 & 71 \\
\hline$M$ & 8,73 & $-0,21$ & 18 & 102 & 62 & 26 & 71 & 4,8 & 100 \\
\hline$F$ & 9,10 & $-0,52$ & 71 & 130 & 74 & 33 & 117 & 4,3 & 99 \\
\hline $\mathrm{F}$ & 9,10 & $-0,7$ & 282 & 86 & 51 & 18 & 85 & 4,2 & 100 \\
\hline $\mathrm{F}$ & 9,17 & $-0,9$ & 79 & 176 & 109 & 19 & 238 & 3,9 & 132 \\
\hline$M$ & 9,87 & $-0,57$ & 20 & 144 & 77 & 42 & 127 & 5 & 138 \\
\hline $\mathrm{F}$ & 11,00 & $-0,43$ & 8 & 131 & 84 & 25 & 108 & 4,2 & 120 \\
\hline $\mathrm{F}$ & 11,37 & $-1,02$ & 8 & 146 & 84 & 35 & 137 & 4,1 & 97 \\
\hline $\mathrm{F}$ & 12,03 & $-0,01$ & 228 & 96 & 44 & 14 & 189 & 4,3 & 101 \\
\hline $\mathrm{M}$ & 12,57 & $-0,49$ & 242 & 118 & 65 & 12 & 207 & 4,1 & 136 \\
\hline $\mathrm{F}$ & 12,87 & $-0,02$ & 85 & 113 & 53 & 35 & 127 & 4,4 & 122 \\
\hline $\mathrm{F}$ & 13,33 & 0,14 & 89 & 139 & 69 & 48 & 111 & 4,4 & 112 \\
\hline$M$ & 14,17 & $-0,8$ & 108 & 125 & 60 & 29 & 181 & 4,9 & 104 \\
\hline$M$ & 14,20 & $-0,73$ & 131 & 136 & 82 & 37 & 84 & 4,6 & 92 \\
\hline$M$ & 14,67 & 1,34 & 19 & 145 & 89 & 38 & 89 & 4,7 & 132 \\
\hline$M$ & 14,80 & $-4,38$ & 40 & 116 & 63 & 32 & 103 & 4,2 & 133 \\
\hline$M$ & 15,03 & $-0,33$ & 99 & 216 & 141 & 60 & 76 & 4,4 & 110 \\
\hline$M$ & 15,83 & $-0,07$ & 48 & 154 & 91 & 46 & 83 & 4,6 & \\
\hline$M$ & 16,63 & $-0,59$ & 358 & 165 & 89 & 6 & 349 & 3,2 & 73 \\
\hline$M$ & 18,00 & 1,57 & 43 & 151 & 106 & 34 & 53 & 4,3 & 100 \\
\hline$F$ & 18,57 & $-0,61$ & 318 & 103 & 29 & 15 & 296 & 3,9 & 133 \\
\hline$M$ & 21,00 & 0,72 & 45 & 115 & 73 & 26 & 81 & 4,6 & 85 \\
\hline $\mathrm{F}$ & 24,53 & $-0,92$ & 166 & 170 & 23 & 20 & 122 & 3,5 & 110 \\
\hline $\mathrm{F}$ & 25,10 & $-0,51$ & 156 & 109 & 56 & 41 & 60 & 5 & 70 \\
\hline$M$ & 27,40 & 1,2 & 239 & 117 & 60 & 44 & 67 & 4,4 & 120 \\
\hline$F$ & 30,03 & 1,72 & 37 & 156 & 86 & 45 & 127 & 4 & 101 \\
\hline$M$ & 30,73 & $-0,69$ & 9 & 65 & 38 & 14 & 58 & 4,5 & 100 \\
\hline$M$ & 30,97 & 0,24 & 74 & 159 & 101 & 46 & 61 & 4,4 & 94 \\
\hline$M$ & 31,67 & 0,42 & 118 & 129 & 67 & 44 & 91 & 4,4 & 139 \\
\hline $\mathrm{F}$ & 32,77 & $-1,61$ & 31 & 130 & 73 & 50 & 37 & 4,4 & 78 \\
\hline $\mathrm{F}$ & 34,30 & $-1,1$ & 17 & 124 & 63 & 50 & 57 & 4,6 & 75 \\
\hline $\mathrm{F}$ & 40,63 & $-0,45$ & 295 & 106 & 29 & 16 & 306 & 3,7 & 118 \\
\hline$M$ & 44,20 & $-0,2$ & 105 & 152 & 80 & 56 & 78 & 4,8 & 104 \\
\hline $\mathrm{M}$ & 44,70 & 0,13 & 87 & 145 & 96 & 38 & 53 & 4,4 & 133 \\
\hline $\mathrm{F}$ & 45,17 & $-1,24$ & 17 & 138 & 65 & 58 & 73 & 4,9 & 149 \\
\hline$M$ & 47,83 & 0,87 & 11 & 143 & 85 & 42 & 78 & 4,2 & 107 \\
\hline$M$ & 48,10 & 0,95 & 16 & 163 & 108 & 47 & 42 & 4,3 & 87 \\
\hline $\mathrm{F}$ & 51,00 & 1,08 & 31 & 173 & 114 & 41 & 91 & 4,2 & 90 \\
\hline $\mathrm{F}$ & 51,17 & 0,52 & 52 & 155 & 101 & 42 & 59 & 4 & 111 \\
\hline
\end{tabular}




\begin{tabular}{|c|c|c|c|c|c|c|c|c|c|}
\hline & & & & & & & & & Continuação \\
\hline Sexo & $\begin{array}{c}\text { Idade } \\
\text { (meses) }\end{array}$ & $\begin{array}{c}\text { IMC: } \\
\text { z-escore }\end{array}$ & $\begin{array}{c}\text { PCR } \\
\text { (mg/L) }\end{array}$ & $\begin{array}{c}\mathrm{CT} \\
(\mathrm{mg} / \mathrm{dL})\end{array}$ & $\begin{array}{c}\mathrm{LDL} \\
\text { (mg/dL) }\end{array}$ & $\begin{array}{c}\text { HDL } \\
\text { (mg/dL) }\end{array}$ & $\begin{array}{c}\text { TG } \\
(\mathrm{mg} / \mathrm{dL}) \\
\end{array}$ & $\begin{array}{c}\text { ALB } \\
\text { (g/dL) }\end{array}$ & DEXTRO \\
\hline $\mathrm{F}$ & 54,13 & 1,35 & 105 & 118 & 70 & 33 & 77 & 4,2 & 101 \\
\hline $\mathrm{M}$ & 56,33 & $-2,24$ & 12 & 108 & 54 & 46 & 40 & 4,2 & 168 \\
\hline $\mathrm{F}$ & 58,60 & $-1,53$ & 20 & 131 & 70 & 38 & 114 & 4,9 & 104 \\
\hline $\mathrm{M}$ & 59,07 & $-0,18$ & 96 & 115 & 50 & 53 & 60 & 4,2 & \\
\hline$F$ & 60,07 & $-0,69$ & 112 & 157 & 72 & 73 & 61 & 4,6 & 106 \\
\hline $\mathrm{F}$ & 62,17 & $-0,45$ & 313 & 149 & 95 & 21 & 166 & 3,8 & 112 \\
\hline $\mathrm{F}$ & 62,63 & 0,31 & 227 & 100 & 52 & 25 & 117 & 4 & 116 \\
\hline $\mathrm{F}$ & 64,13 & 1,15 & 35 & 122 & 65 & 44 & 64 & 4,6 & 169 \\
\hline M & 65,40 & 5,52 & 248 & 61 & 12 & 37 & 58 & 4,3 & 147 \\
\hline $\mathrm{F}$ & 67,67 & $-0,08$ & 20 & 121 & 59 & 50 & 58 & 4,1 & 94 \\
\hline M & 71,83 & $-0,5$ & 129 & 153 & 89 & 52 & 60 & 4,4 & 103 \\
\hline $\mathrm{F}$ & 77,77 & 2,81 & 35 & 137 & 73 & 39 & 123 & 4,4 & 111 \\
\hline $\mathrm{F}$ & 78,33 & 1,86 & 34 & 145 & 80 & 51 & 70 & 4,5 & 101 \\
\hline $\mathrm{F}$ & 78,77 & 1,91 & 31 & 120 & 57 & 54 & 46 & 5,2 & 81 \\
\hline $\mathrm{F}$ & 79,87 & 0,46 & 101 & 148 & 94 & 37 & 84 & 4,8 & 121 \\
\hline $\mathrm{M}$ & 80,93 & $-1,52$ & 116 & 96 & 58 & 22 & 78 & 4,1 & 88 \\
\hline$F$ & 89,70 & 1,58 & 139 & 159 & 109 & 35 & 73 & 4,4 & 89 \\
\hline $\mathrm{F}$ & 94,20 & 1,3 & 14 & 142 & 75 & 60 & 34 & 4,7 & 158 \\
\hline $\mathrm{F}$ & 94,90 & $-0,63$ & 22 & 155 & 80 & 49 & 130 & 4,7 & 121 \\
\hline $\mathrm{M}$ & 96,67 & $-2,68$ & 31 & 132 & 27 & 92 & 64 & 4,1 & 98 \\
\hline M & 97,87 & 2,01 & 45 & 128 & 66 & 49 & 66 & 4,7 & 112 \\
\hline $\mathrm{M}$ & 100,67 & $-0,61$ & 12 & 187 & 134 & 47 & 29 & 4,7 & 99 \\
\hline M & 108,57 & 0,95 & 141 & 122 & 76 & 24 & 110 & 3,4 & 112 \\
\hline $\mathrm{F}$ & 109,33 & $-2,26$ & 8 & 132 & 85 & 31 & 79 & 4,1 & 83 \\
\hline M & 115,70 & 2,83 & 19 & 136 & 92 & 36 & 42 & 4 & 87 \\
\hline M & 119,07 & $-0,88$ & 6 & 160 & 90 & 60 & 50 & 4,9 & 106 \\
\hline M & 119,93 & $-0,12$ & 75 & 185 & 99 & 66 & 98 & 4,4 & 113 \\
\hline $\mathrm{M}$ & 127,07 & $-1,04$ & 15 & 125 & 60 & 60 & 23 & 4,5 & 168 \\
\hline M & 132,30 & 1,66 & 7 & 173 & 104 & 62 & 33 & 4,5 & 135 \\
\hline $\mathrm{M}$ & 133,07 & $-2,68$ & 12 & 127 & 76 & 44 & 35 & 4,4 & 121 \\
\hline $\mathrm{M}$ & 133,93 & $-0,59$ & 19 & 112 & 60 & 35 & 84 & 4,4 & 99 \\
\hline $\mathrm{F}$ & 140,83 & 1,09 & 14 & 122 & 72 & 41 & 44 & 4,5 & 111 \\
\hline $\mathrm{M}$ & 142,13 & 1,72 & 10 & 135 & 87 & 40 & 41 & 4,6 & 121 \\
\hline $\mathrm{M}$ & 148,33 & $-0,79$ & 13 & 161 & 91 & 54 & 82 & 4,5 & 91 \\
\hline $\mathrm{M}$ & 149,33 & $-0,88$ & 6 & 174 & 112 & 47 & 77 & 4,5 & 100 \\
\hline $\mathrm{M}$ & 151,93 & 1,19 & 117 & 138 & 91 & 33 & 71 & 4,6 & 90 \\
\hline M & 178,93 & 1,95 & 13 & 85 & 47 & 25 & 64 & 4,4 & 83 \\
\hline
\end{tabular}

$M=$ Masculino; $F=$ Feminino 


\section{Anexo D - Planilha de dados referente ao Grupo II}

\begin{tabular}{|c|c|c|c|c|c|c|c|c|c|}
\hline Sexo & $\begin{array}{c}\text { Idade } \\
\text { (meses) }\end{array}$ & $\begin{array}{c}\text { IMC } \\
\text { z-escore }\end{array}$ & $\begin{array}{c}\text { PCR } \\
\text { (mg/L) }\end{array}$ & $\begin{array}{c}C T \\
\text { (mg/dL) }\end{array}$ & $\begin{array}{c}\text { LDL } \\
\text { (mg/dL) }\end{array}$ & $\begin{array}{c}\text { HD } \\
\text { (mg/dL) }\end{array}$ & $\begin{array}{c}\text { TG } \\
\text { (mg/dL) }\end{array}$ & $\begin{array}{c}\text { ALB } \\
\text { (g/dL) }\end{array}$ & DEXTRO \\
\hline$M$ & 3,77 & 0,55 & $<5$ & 91 & 30 & 21 & 198 & 4,4 & 104 \\
\hline$M$ & 4,20 & $-3,94$ & $<5$ & 94 & 26 & 44 & 119 & 4,6 & 107 \\
\hline$M$ & 4,83 & 0,49 & $<5$ & 209 & 117 & 39 & 263 & 4,4 & 88 \\
\hline $\mathrm{F}$ & 7,33 & 0,04 & $<5$ & 110 & 56 & 18 & 182 & 4,3 & 109 \\
\hline $\mathrm{F}$ & 8,23 & 0,62 & $<5$ & 182 & 98 & 41 & 213 & 4,7 & 113 \\
\hline $\mathrm{F}$ & 9,30 & 0,46 & $<5$ & 158 & 112 & 27 & 97 & 4 & 142 \\
\hline M & 11,63 & 0,73 & $<5$ & 159 & 84 & 35 & 199 & 4,2 & 94 \\
\hline$M$ & 13,50 & 0 & $<5$ & 164 & 98 & 27 & 194 & 4,9 & 123 \\
\hline$M$ & 17,07 & $-1,31$ & $<5$ & 155 & 104 & 45 & 28 & 4,9 & 82 \\
\hline$M$ & 19,57 & $-1,35$ & $<5$ & 89 & 36 & 30 & 117 & 4,5 & 90 \\
\hline $\mathrm{F}$ & 25,53 & 1,24 & $<5$ & 126 & 105 & 53 & 69 & 4,3 & 92 \\
\hline $\mathrm{F}$ & 27,03 & 2,09 & $<5$ & 116 & 62 & 31 & 115 & 4,3 & 88 \\
\hline $\mathrm{F}$ & 27,93 & 1,44 & $<5$ & 153 & 82 & 53 & 90 & 4,6 & 69 \\
\hline $\mathrm{F}$ & 32,93 & 0,63 & $<5$ & 112 & 66 & 36 & 50 & 4,1 & 141 \\
\hline $\mathrm{F}$ & 33,87 & $-1,07$ & $<5$ & 107 & 63 & 30 & 72 & 4,3 & 56 \\
\hline M & 37,57 & $-0,46$ & $<5$ & 121 & 84 & 21 & 81 & 4,1 & 93 \\
\hline$M$ & 43,13 & 0,21 & $<5$ & 154 & 90 & 49 & 73 & 4,5 & 84 \\
\hline$M$ & 48,10 & -2 & $<5$ & 118 & 64 & 42 & 59 & 4,6 & 103 \\
\hline$F$ & 54,47 & 2,58 & $<5$ & 122 & 64 & 37 & 107 & 4,2 & 102 \\
\hline $\mathrm{F}$ & 57,47 & $-0,84$ & $<5$ & 169 & 97 & 66 & 31 & 4,9 & 120 \\
\hline$M$ & 65,00 & 1,53 & $<5$ & 92 & 53 & 29 & 49 & 4,1 & 86 \\
\hline$M$ & 68,30 & 0,26 & $<5$ & 141 & 90 & 36 & 74 & 4,1 & 83 \\
\hline $\mathrm{F}$ & 74,63 & 1,35 & $<5$ & 151 & 101 & 42 & 42 & 4,8 & 83 \\
\hline$M$ & 83,37 & 0,12 & $<5$ & 142 & 88 & 43 & 57 & 4,4 & 85 \\
\hline $\mathrm{F}$ & 83,67 & $-2,05$ & $<5$ & 156 & 107 & 42 & 37 & 4,7 & 101 \\
\hline$M$ & 87,33 & 0,9 & $<5$ & 177 & 100 & 62 & 75 & 4,5 & 104 \\
\hline $\mathrm{F}$ & 87,77 & 0,64 & $<5$ & 164 & 68 & 81 & 77 & 4,4 & 85 \\
\hline$M$ & 92,43 & $-0,56$ & $<5$ & 161 & 80 & 67 & 72 & 4,8 & 110 \\
\hline $\mathrm{F}$ & 94,93 & 1,71 & $<5$ & 169 & 105 & 36 & 139 & 4,3 & 100 \\
\hline $\mathrm{F}$ & 96,73 & $-1,5$ & $<5$ & 164 & 109 & 30 & 125 & 4,5 & 89 \\
\hline$F$ & 99,90 & 0,44 & $<5$ & 107 & 57 & 31 & 93 & 4,3 & 85 \\
\hline $\mathrm{F}$ & 103,00 & 2,53 & $<5$ & 140 & 87 & 32 & 103 & 4,6 & 90 \\
\hline$M$ & 106,83 & $-0,39$ & $<5$ & 223 & 127 & 83 & 67 & 4,8 & 137 \\
\hline$M$ & 111,30 & $-1,52$ & $<5$ & 97 & 62 & 21 & 71 & 4,5 & 91 \\
\hline$M$ & 122,27 & $-1,52$ & $<5$ & 130 & 64 & 43 & 114 & 4,2 & 100 \\
\hline $\mathrm{F}$ & 146,83 & 1,03 & $<5$ & 92 & 48 & 36 & 42 & 5 & 94 \\
\hline $\mathrm{F}$ & 148,30 & $-0,08$ & $<5$ & 157 & 104 & 43 & 50 & 4,3 & 108 \\
\hline$M$ & 157,43 & $-1,1$ & $<5$ & 145 & 86 & 23 & 181 & 3,7 & 94 \\
\hline$M$ & 168,00 & 1 & $<5$ & 160 & 94 & 55 & 54 & 4,3 & 102 \\
\hline $\mathrm{F}$ & 169,00 & $-1,43$ & $<5$ & 193 & 129 & 54 & 50 & 4 & \\
\hline $\mathrm{F}$ & 170,37 & $-1,47$ & $<5$ & 164 & 68 & 50 & 230 & 4,5 & 97 \\
\hline $\mathrm{F}$ & 177,07 & $-0,03$ & $<5$ & 145 & 87 & 46 & 61 & 4,2 & 100 \\
\hline
\end{tabular}

$\mathrm{M}=$ Masculino; $\mathrm{F}=$ Feminino 


\section{Anexo E - Ficha para coleta de dados}

\begin{tabular}{|c|c|c|}
\hline DATA & \multirow{2}{*}{\multicolumn{2}{|c|}{ IDENTIFICAÇÃO (etiqueta) }} \\
\hline DATA NASCIMENTO & & \\
\hline $\begin{array}{l}\text { ENDEREÇO } \\
\text { (envio do resultado } \\
\text { do exame pelo } \\
\text { correio) }\end{array}$ & & \\
\hline \multicolumn{3}{|l|}{ DIAGNOSTICO } \\
\hline \multicolumn{3}{|l|}{$\begin{array}{l}\text { ANTECEDENTES } \\
\text { RELEVANTES }\end{array}$} \\
\hline \multicolumn{3}{|l|}{$\begin{array}{l}\text { MEDICAÇÕES } \\
\text { EM USO }\end{array}$} \\
\hline \multicolumn{3}{|l|}{$\begin{array}{l}\text { ALEITAMENTO } \\
\text { MATERNO (tempo) }\end{array}$} \\
\hline $\begin{array}{l}\text { TEMPO DE JEJUM } \\
\text { (até a coleta) }\end{array}$ & DEXTRO & \\
\hline PESO & ESTATURA & \\
\hline OBSERVAÇÃO & & \\
\hline
\end{tabular}

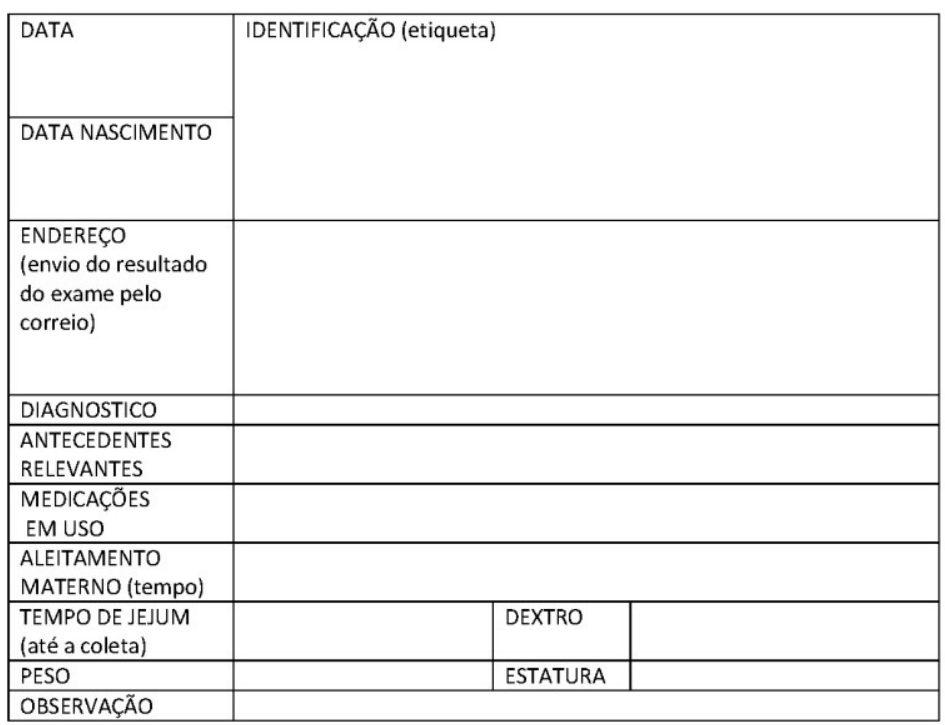




\section{REFERÊNCIAS}


Aburawi EH, Grubb A, Raitakari OT, Viikari J, Pesonen EJ. Lowered levels of serum albumin and HDL-cholesterol in children with a recent mild infection. Ann Med. 2006; 38(2):154-60.

Alvarez C, Ramos A. Lipids, lipoproteins, and apoproteins in serum during infection. Clin Chem. 1986;32:142-5.

Back Giuliano Ide C, Caramelli B, Pellanda L, Duncan B, Mattos S, Fonseca FH; Sociedade Brasileira de Cardiologia. I Diretriz de Prevenção da Aterosclerose na infância e na adolescência. Arq Bras Cardiol. 2005; 85(Suppl 6):4-36.

Bafadhel M, Clark TW, Reid C, Medina MJ, Batham S, Barer MR, Nicholson KG, Brightling CE. Procalcitonin and C-reactive protein in hospitalized adult patients with community-acquired pneumonia or exacerbation of asthma or COPD. Chest. 2011; 139(6):1410-8

Barter P, Gotto AM, LaRosa JC, Maroni J, Szarek M, Grundy SM, Kastelein JJ, Bittner V, Fruchart JC; Treating to New Targets Investigators. HDL cholesterol, very low levels of LDL cholesterol, and cardiovascular events. $N$ Engl J Med. 2007; 357(13):1301-10. 
Berbée JF, van der Hoogt CC, Kleemann R, Schippers EF, Kitchens RL, van Dissel JT, Bakker-Woudenberg IA, Havekes LM, Rensen PC. Apolipoprotein $\mathrm{Cl}$ stimulates the response to lipopolysaccharide and reduces mortality in Gram-negative sepsis. FASEB J. 2006; 20(12):2162-4

Berenson GS, Srinivasan SR, Bao W, Newman WP 3rd, Tracy RE, Wattigney WA. Association between multiple cardiovascular risk factors and atherosclerosis in children and young adults. The Bogalusa Heart Study. $N$ Engl J Med. 1998; 338(23):1650-6.

Birjmohun RS, van Leuven SI, Levels JH, van 't Veer C, Kuivenhoven JA, Meijers JC, Levi M, Kastelein JJ, van der Poll T, Stroes ES. High-density lipoprotein attenuates inflammation and coagulation response on endotoxin challenge in humans. Arterioscler Thromb Vasc Biol. 2007; 27(5):1153-8.

Black S, Kushner I, Samols D. C-reactive Protein. J Biol Chem. 2004; 279(47):48487-90.

Cappi SB, Noritomi DT, Velasco IT, Curi R, Loureiro TC, Soriano FG. Dyslipidemia: a prospective controlled randomized trial of intensive glycemic control in sepsis. Intensive Care Med. 2012; 38(4):634-41.

Centers for Disease Control and Prevention (CDC). Prevalence of abnormal lipid levels among youths - United States, 1999-2006. MMWR Morb Mortal Wkly Rep. 2010; 59(2):29-33. 
Chenaud C, Merlani PG, Roux-Lombard P, Burger D, Harbarth S, Luyasu S, Graf JD, Dayer JM, Ricou B. Low apolipoprotein A-I level at intensive care unit admission and systemic inflammatory response syndrome exacerbation. Crit Care Med. 2004; 32(3):632-7.

Chiarla C, Giovannini I, Giuliante F, Zadak Z, Vellone M, Ardito F, Clemente G, Murazio M, Nuzzo G. Severe hypocholesterolemia in surgical patients, sepsis, and critical illness. J Crit Care. 2010; 25(2):361.e7-361.e12.

Chien JY, Jerng JS, Yu CJ, Yang PC. Low serum level of high-density lipoprotein cholesterol is a poor prognostic factor for severe sepsis. Crit Care Med. 2005; 33(8):1688-93.

Dalpino FB, Sodré FL, de Faria EC. The use of a hospital laboratory cohort to estimate the prevalence of dyslipidemia in an adult Brazilian population. Clin Chim Acta. 2006; 367(1-2):189-91.

Dati F, Schumann G, Thomas L, Aguzzi F, Baudner S, Bienvenu J, Blaabjerg O, Blirup-Jensen S, Carlström A, Petersen PH, Johnson AM, Milford-Ward A, Ritchie RF, Svendsen PJ, Whicher J. Consensus of a group of professional societies and diagnostic companies on guidelines for interim reference ranges for 14 proteins in serum based on the standardization against the IFCC/BCR/CAP Reference Material (CRM 470). International Federation of Clinical Chemistry. Community Bureau of Reference of the Commission of the European Communities. College of American Pathologists. Eur J Clin Chem Clin Biochem. 1996; 34(6):517-20. 
de Alcântara Neto OD, Silva RC, Assis AM, Pinto EJ. Factors associated with dyslipidemia in children and adolescents enrolled in public schools of Salvador, Bahia. Rev Bras Epidemiol. 2012; 15(2):335-45.

De Angelis LC. Fisiologia da nutrição humana: aspectos básicos, aplicados e funcionais. 2 ed. São Paulo. Atheneu, 2007. p. 49-68.

de la Llera Moya M, McGillicuddy FC, Hinkle CC, Byrne M, Joshi MR, Nguyen V, Tabita-Martinez J, Wolfe ML, Badellino K, Pruscino L, Mehta NN, Asztalos BF, Reilly MP. Inflammation modulates human HDL composition and function in vivo. Atherosclerosis. 2012; 222(2):390-4.

Delgado AF, Okay TS, Leone C, Nichols B, Del Negro GM, Vaz FA. Hospital malnutrition and inflammatory response in critically ill children and adolescents admitted to a tertiary intensive care unit. Clinics (Sao Paulo). 2008; 63(3):357-62.

Flanders AS, Stein J, Shochat G, Sellers K, Holland M, Maselli J, Drew WL, Reingold AL, Gonzales R. Performance of a bedside C-reactive protein test in the diagnosis of community-acquired pneumonia in adults with acute cough. Am J Med. 2004; 116(8):529-35.

Fruchart JC, Ailhaud G. Apolipoprotein A-containing lipoprotein particles: physiological role, quantification, and clinical significance. Clin Chem. 1992; 38(6):793-7.

Gabay C, Kushner I Acute-phase proteins and other systemic responses to inflammation. Gabay C, Kushner I. N Engl J Med. 1999; 340(6):448-54. 
Gabay C, Smith MF, Eidlen D, Arend WP. Interleukin 1 receptor antagonist (IL-1Ra) is an acute-phase protein. J Clin Invest. 1997; 99(12):2930-40.

Galetto-Lacour A, Alcoba G, Posfay-Barbe KM, Cevey-Macherel M, Gehri M, Ochs MM, Brookes RH, Siegrist CA, Gervaix A. Elevated inflammatory markers combined with positive pneumococcal urinary antigen are a good predictor of pneumococcal community-acquired pneumonia in children. Pediatr Infect Dis J. 2013; 32(11):1175-9.

Gama SR, Carvalho MS, Chaves CR. Childhood prevalence of cardiovascular risk factors. Cad Saude Publica. 2007; 23(9):2239-45.

Gidding SS, Stone NJ, Bookstein LC, Laskarzewski PM, Stein EA. Month-tomonth variability of lipids, lipoproteins, and apolipoproteins and the impact of acute infection in adolescents. J Pediatr. 1998; 133(2):242-6.

Giuliano Ide C, Coutinho MS, Freitas SF, Pires MM, Zunino JN, Ribeiro RQ. Serum lipids in school kids and adolescents from Florianópolis, SC, Brazil-Healthy Floripa 2040 study. Arq Bras Cardiol. 2005; 85(2):85-91.

Gordon BR, Parker TS, Levine DM, Saal SD, Wang JC, Sloan BJ, Barie PS, Rubin AL. Relationship of hypolipidemia to cytokine concentrations and outcomes in critically ill surgical patients. Crit Care Med. 2001; 29(8):1563-8.

Gotto AM Jr. Apolipoproteins and metabolism in atherosclerosis. Trans Am Clin Climatol Assoc. 1990; 101:46-57. 
Grion CM, Cardoso LT, Perazolo TF, Garcia AS, Barbosa DS, Morimoto HK, Matsuo T, Carrilho AJ. Lipoproteins and CETP levels as risk factors for severe sepsis in hospitalized patients. Eur J Clin Invest. 2010; 40(4):330-8.

Guo L, Ai J, Zheng Z, Howatt DA, Daugherty A, Huang B, Li XA. High density lipoprotein protects against polymicrobe-induced sepsis in mice. $J$ Biol Chem. 2013; 288(25):17947-53.

Hansson GK. Inflammation, atherosclerosis, and coronary artery disease. $N$ Engl J Med. 2005; 352(16):1685-95.

Hartiala O, Magnussen CG, Kajander S, Knuuti J, Ukkonen H, Saraste A, RintaKiikka I, Kainulainen S, Kähönen M, Hutri-Kähönen N, Laitinen T, Lehtimäki T, Viikari JS, Hartiala J, Juonala M, Raitakari OT. Adolescence risk factors are predictive of coronary artery calcification at middle age: the cardiovascular risk in young Finns study. J Am Coll Cardiol. 2012; 60(15):1364-70.

Hudgins LC, Parker TS, Levine DM, Gordon BR, Saal SD, Jiang XC, Seidman CE, Tremaroli JD, Lai J, Rubin AL. A single intravenous dose of endotoxin rapidly alters serum lipoproteins and lipid transfer proteins in normal volunteers. J Lipid Res. 2003; 44(8):1489-98.

Imai T, Fujita T, Yamazaki Y. Beneficial effects of apolipoprotein A-I on endotoxemia. Surg Today. 2003; 33(9):684-7.

Irizarry KA, Brito V, Freemark M. Screening for metabolic and reproductive complications in obese children and adolescents. Pediatr Ann. 2014; 43(9):e210-7. 
Jaye DL, Waites KB. Clinical applications of C-reactive protein in pediatrics. Pediatr Infect Dis J. 1997; 16(8):735-46.

Jialal I, Devaraj S, Venugopal SK. C-reactive protein: risk marker or mediator in atherothrombosis? Hypertension. 2004; 44(1):6-11.

Jiao YL, Wu MP. Apolipoprotein A-I diminishes acute lung injury and sepsis in mice induced by lipoteichoic acid. Cytokine. 2008; 43(1):83-7.

Juonala M, Magnussen CG, Berenson GS, Venn A, Burns TL, Sabin MA, Srinivasan SR, Daniels SR, Davis PH, Chen W, Sun C, Cheung M, Viikari JS, Dwyer T, Raitakari OT. Childhood adiposity, adult adiposity, and cardiovascular risk factors. N Engl J Med. 2011; 365(20):1876-85.

Juonala M, Magnussen CG, Venn A, Dwyer T, Burns TL, Davis PH, Chen W, Srinivasan SR, Daniels SR, Kähönen M, Laitinen T, Taittonen L, Berenson GS, Viikari JS, Raitakari OT. Influence of age on associations between childhood risk factors and carotid intima-media thickness in adulthood: the Cardiovascular Risk in Young Finns Study, the Childhood Determinants of Adult Health Study, the Bogalusa Heart Study, and the Muscatine Study for the International Childhood Cardiovascular Cohort (i3C) Consortium. Circulation. 2010; 122(24):2514-20.

Kallio KA, Buhlin K, Jauhiainen M, Keva R, Tuomainen AM, Klinge B, Gustafsson A, Pussinen PJ. Lipopolysaccharide associates with proatherogenic lipoproteins in periodontitis patients. Innate Immun. 2008; 14(4):247-53. 
Karlsson H, Leanderson P, Tagesson C, Lindahl M. Lipoproteomics II: mapping of proteins in high-density lipoprotein using two-dimensional gel electrophoresis and mass spectrometry. Proteomics. 2005; 5(5):1431-45.

Kilickap M, Goksuluk H, Candemir B, Kaya CT, Ozcan OU, Turhan S, Vurgun K, Ozdemir AO, Erol C. Evaluation of acute infection-induced endothelial dysfunction and its potential mediators. Acta Cardiol. 2011; 66(5):581-7.

Kit BK, Carroll MD, Lacher DA, Sorlie PD, DeJesus JM, Ogden C. Trends in serum lipids among US youths aged 6 to 19 years, 1988-2010. JAMA. 2012; 308(6):591-600 .

Kronenberg HM, Melmed S, Polonsky K, Laqrsen PR. Williams tratado de endocrinologia. 11ª ed. São Paulo: Elservier, 2010.

Kushner I, Rzewnicki D, Samols. What does minor elevation of C-reactive protein signify? Am J Med. 2006; 119(2):166.e17-28.

Lagrost L, Girard C, Grosjean S, Masson D, Deckert V, Gautier T, Debomy F, Vinault S, Jeannin A, Labbé J, Bonithon-Kopp C. Low preoperative cholesterol level is a risk factor of sepsis and poor clinical outcome in patients undergoing cardiac surgery with cardiopulmonary bypass. Crit Care Med. 2014; 42(5):1065-73.

Lakio L, Lehto M, Tuomainen AM, Jauhiainen M, Malle E, Asikainen S, Pussinen PJ. Pro-atherogenic properties of lipopolysaccharide from the periodontal pathogen Actinobacillus actinomycetemcomitans. J Endotoxin Res. 2006; 12(1):57-64. 
Lépori LR. Miniatlas colesterol y aterosclerosis. Buenos Aires: E.C.S.A., 2003. p. 15-33.

Levels JH, Lemaire LC, van den Ende AE, van Deventer SJ, van Lanschot JJ. Lipid composition and lipopolysaccharide binding capacity of lipoproteins in plasma and lymph of patients with systemic inflammatory response syndrome and multiple organ failure. Crit Care Med. 2003; 31(6):1647-53.

Li S, Chen W, Srinivasan SR, Bond MG, Tang R, Urbina EM, Berenson GS. Childhood cardiovascular risk factors and carotid vascular changes in adulthood: the Bogalusa Heart Study. JAMA. 2003; 290(17):2271-6.

Li S, Chen W, Srinivasan SR, Xu J, Berenson GS. Relation of childhood obesity/cardiometabolic phenotypes to adult cardiometabolic profile: the Bogalusa Heart Study. Am J Epidemiol. 2012; 176(Suppl 7):S142-9.

Liuba P, Persson J, Luoma J, Ylä-Herttuala S, Pesonen E. Acute infections in children are accompanied by oxidative modification of LDL and decrease of HDL cholesterol, and are followed by thickening of carotid intima-media. Eur Heart J. 2003; 24(6):515-21.

Lobo SM, Lobo FR, Bota DP, Lopes-Ferreira F, Soliman HM, Mélot C, Vincent JL. C-reactive protein levels correlate with mortality and organ failure in critically il patients. Chest. 2003; 123:2043-9. 
Magnussen CG, Koskinen J, Juonala M, Chen W, Srinivasan SR, Sabin MA, Thomson R, Schmidt MD, Nguyen QM, Xu JH, Skilton MR, Kähönen M, Laitinen T, Taittonen L, Lehtimäki T, Rönnemaa T, Viikari JS, Berenson GS, Raitakari OT. A diagnosis of the metabolic syndrome in youth that resolves by adult life is associated with a normalization of high carotid intima-media thickness and type 2 diabetes mellitus risk: the Bogalusa heart and cardiovascular risk in young Finns studies. J Am Coll Cardiol. 2012; 60(17):1631-9.

Magnussen CG, Venn A, Thomson R, Juonala M, Srinivasan SR, Viikari JS, Berenson GS, Dwyer T, Raitakari OT. The association of pediatric low- and high-density lipoprotein cholesterol dyslipidemia classifications and change in dyslipidemia status with carotid intima-media thickness in adulthood evidence from the cardiovascular risk in Young Finns study, the Bogalusa Heart study, and the CDAH (Childhood Determinants of Adult Health) study. J Am Coll Cardiol. 2009; 53(10):860-9.

Mahley RW, Innerarity TL, Rall SC Jr, Weisgraber KH. Plasma lipoproteins: apolipoprotein structure and function. J Lipid Res. 1984; 25(12):1277-94.

Mahley RW, Weisgraber $\mathrm{KH}$, Bersot TP. Distúrbios do metabolismo de lipídios. In: Kronenberg HM, Melmed S, Polonsky KS, Larsen PR. Tratado de endocrinologia. Rio de Janeiro: Elservier, 2010.

Marsche G, Saemann MD, Heinemann A, Holzer M. Inflammation alters HDL composition and function: implications for HDL-raising therapies. Pharmacol Ther. 2013; 137(3):341-51. 
Matsuura E, Kobayashi K, Matsunami Y, Shen L, Quan N, Makarova M, Suchkov SV, Ayada K, Oguma K, Lopez LR. Autoimmunity, infectious immunity, and atherosclerosis. J Clin Immunol. 2009; 29(6):714-21.

Mazaro IA, Zanolli ML, Antonio MA, Morcillo AM, Zambon MP. Obesity and cardiovascular risk factors in school children from Sorocaba, SP. Rev Assoc Med Bras. 2011; 57(6):674-80.

Morimoto M, Nakamura Y, Atsuko S, Nagaie T, Shirabe K. Serum total cholesterol in nosocomial infections after gastrointestinal surgery. World $J$ Surg. 2010; 34(9):2051-6.

Morrison JA, Glueck CJ, Wang P. Childhood risk factors predict cardiovascular disease, impaired fasting glucose plus type 2 diabetes mellitus, and high blood pressure 26 years later at a mean age of 38 years: the Princeton-lipid research clinics follow-up study. Metabolism. 2012; $61(4): 531-41$

Moura EC, de Castro CM, Mellin AS, de Figueiredo DB. Lipid profile among school children in Campinas, Brazil. Rev Saude Publica. 2000; 34(5):499-505.

Murch O, Collin M, Hinds CJ, Thiemermann C Lipoproteins in inflammation and sepsis. I. Basic science. Intensive Care Med. 2006; 33(1):13-24

National Heart, Lung, and Blood Institute. Expert panel on integrated guidelines for cardiovascular health and risk reduction in children and adolescents: NIH Publication No. 12-7486A October 2012. Disponível em: <http://www.nhlbi.nih. gov/guidelines/cvd_ped/index.htm>. Acesso em 19 jun 2014. 
Nemeth E, Valore EV, Territo M, Schiller G, Lichtenstein A, Ganz T. Hepcidin, a putative mediator of anemia of inflammation, is a type II acutephase protein. Blood. 2003; 101(7):2461-3.

Niehues JR, Gonzales Al, Lemos RR, Bezerra PP, Haas P. Prevalence of overweight and obesity in children and adolescents from the age range of 2 to 19 years old in Brazil. Int J Pediatr. 2014; 2014:583207.

Nijman RG, Vergouwe $Y$, Thompson M, van Veen M, van Meurs AH, van der Lei J, Steyerberg EW, Moll HA, Oostenbrink R. Clinical prediction model to aid emergency doctors managing febrile children at risk of serious bacterial infections: diagnostic study. BMJ. 2013; 346:f1706.

Nijsten MW, Olinga P, The TH, de Vries EG, Koops HS, Groothuis GM, Limburg PC, ten Duis HJ, Moshage H, Hoekstra HJ, Bijzet J, Zwaveling JH. Procalcitonin behaves as a fast responding acute phase protein in vivo and in vitro. Crit Care Med. 2000; 28(2):458-61.

Oliveira FLC. Metabolismo de lipídios. Uso do ômega-3 e ômega-6, lipídios estruturados e de cadeias média e curta. In: Telles Júnior M, Leite HP. Terapia nutricional no paciente pediátrico grave. São Paulo: Atheneu, 2005.

OMS AnthroPlus. Disponível em: <http://who-anthroplus.software.informer. com/>. Acesso em: 21 jun 2012

Organização Mundial da Saúde (OMS). BMI-for-age (5-19 years). Disponível em: <http://www.who.int/growthref/who2007_bmi_for_age/en/>. Acesso em 22 abr.2014b. 
Organização Mundial da Saúde (OMS). Growth reference 5-19 years. Disponível em: <http://www.who.int/childgrowth/standards/bmi_for_age/en/>. Acesso em 22 jun 2012.

Organização Mundial da Saúde (OMS). Nutrition Landscape Information System (NLiS). Disponívle em: <http://apps.who.int/nutrition/landscape /report.aspx?iso=bra>. Acesso em nov 2014a.

Pearson TA, Mensah GA, Alexander RW, Anderson JL, Cannon RO 3rd, Criqui M, Fadl YY, Fortmann SP, Hong Y, Myers GL, Rifai N, Smith SC Jr, Taubert K, Tracy RP, Vinicor F; Centers for Disease Control and Prevention; American Heart Association. Markers of inflammation and cardiovascular disease: application to clinical and public health practice: A statement for healthcare professionals from the Centers for Disease Control and Prevention and the American Heart Association. Circulation. 2003; 107(3):499-511.

Pereira A, Guedes AD, Verreschi IT, Santos RD, Martinez TL. Obesity and its association with other cardiovascular risk factors in school children in Itapetininga, Brazil. Arq Bras Cardiol. 2009; 93(3):253-60.

Raitakari OT. Cardiovascular risk prediction in children and adolescents. Clin Biochem. 2014; 47(9):722-3.

Ravnskov U, McCully KS. Infections may be causal in the pathogenesis of atherosclerosis. Am J Med Sci. 2012; 344(5):391-4. 
Ribas SA, Silva LCS. Dislipidemia em escolares na rede privada de Belém. Arq Bras Cardiol. 2009; 92:446-51.

Rodríguez-Sanz A, Fuentes B, Martínez-Sánchez P, Prefasi D, MartínezMartínez M, Correas E, Díez-Tejedor E. High-density lipoprotein: a novel marker for risk of in-hospital infection in acute ischemic stroke patients? Cerebrovasc Dis. 2013; 35(3):291-7.

ROMALDINI CC. Abordagem da hiperlipidemia em crianças e adolescentes. In: Delgado AF, Cardoso AL, Zamberlan P (Coords.). Nutrologia básica e avançada. Barueri, SP: Manole, 2010.

Rosenson RS, Brewer HB Jr, Davidson WS, Fayad ZA, Fuster V, Goldstein J, Hellerstein M, Jiang XC, Phillips MC, Rader DJ, Remaley AT, Rothblat GH, Tall AR, Yvan-Charvet L. Cholesterol efflux and atheroprotection: advancing the concept of reverse cholesterol transport. Circulation. 2012; 125(15):1905-19.

Schrott HG, Clarke WR, Abrahams P, Wiebe DA, Lauer RM. Coronary artery disease mortality in relatives of hypertriglyceridemic school children: the Muscatine study. Circulation. 1982; 65(2):300-5.

Schrott HG, Clarke WR, Wiebe DA, Connor WE, Lauer RM. Increased coronary mortality in relatives of hypercholesterolemic school children: the Muscatine study. Circulation. 1979; 59(2):320-6.

Smith RP, Lipworth BJ, Cree IA, Spiers EM, Winter JH. C-reactive protein. A Clinical marcker in community-acquired pneumonia. Chest. 1995; 108(5):1288-91. 
Sociedade Brasileira de Pediatria (SBP). Obesidade na infância e adolescência - Manual de Orientação. São Paulo: Sociedade Brasileira de Pediatria. Departamento de Nutrologia, 2008; n.i.:13-14.

Soran H, Hama S, Yadav R, Durrington PN. HDL functionality. Curr Opin Lipidol. 2012; 23(4):353-66.

Sposito AC, Caramelli B, Fonseca FA, Bertolami MC, Afiune Neto A, Souza AD, Lottenberg AM, Chacra AP, Faludi AA, Loures-Vale AA, Carvalho AC, Duncan B, Gelonese B, Polanczyk C, Rodrigues Sobrinho CR, Scherr C, Karla C, Armaganijan D, Moriguchi E, Saraiva F, Pichetti G, Xavier HT, Chaves H, Borges JL, Diament J, Guimarães JI, Nicolau JC, dos Santos JE, de Lima JJ, Vieira JL, Novazzi JP, Faria Neto JR, Torres KP, Pinto Lde A, Bricarello L, Bodanese LC, Introcaso L, Malachias MV, Izar MC, Magalhães ME, Schmidt MI, Scartezini M, Nobre M, Foppa M, Forti NA, Berwanger O, Gebara OC, Coelho OR, Maranhão RC, dos Santos Filho RD, Costa RP, Barreto S, Kaiser S, Ihara S, Carvalho Td, Martinez TL, Relvas WG, Salgado W; Sociedade Brasileira de Cardiologia. IV Brazilian Guideline for Dyslipidemia and Atherosclerosis prevention: Department of Atherosclerosis of Brazilian Society of Cardiology]. Arq Bras Cardiol. 2007; (88 Suppl 1):2-19.

Tall AR. Plasma High Density Lipoproteins. Metabolism and relationship to atherogenesis. J Clin Invest. 1990; 86(2):379-84.

Torrinhas RSMM, Campos LDN, Waitzberg DL. Gorduras. In: Waitzberg DL. Nutrição oral, enteral e parenteral na pratica clínica. $4^{a}$ ed. São Paulo: Atheneu; 2009. p. 121-148. 
Toth PP, Barter PJ, Rosenson RS, Boden WE, Chapman MJ, Cuchel M, D'Agostino RB Sr, Davidson MH, Davidson WS, Heinecke JW, Karas RH, Kontush A, Krauss RM, Miller M, Rader DJ. High-density lipoproteins: a consensus statement from the National Lipid Association. J Clin Lipidol. $2013 ; 7(5): 484-525$.

van Leeuwen HJ, Heezius EC, Dallinga GM, van Strijp JA, Verhoef J, van Kessel KP. Lipoprotein metabolism in patients with severe sepsis. Crit Care Med. 2003; 31(5):1359-66.

Vermont CL, den Brinker M, Kâkeci N, de Kleijn ED, de Rijke YB, Joosten KF, de Groot R, Hazelzet JA. Serum lipids and disease severity in children with severe meningococcal sepsis. Crit Care Med. 2005; 33(7):1610-5.

Vyroubal P, Chiarla C, Giovannini I, Hyspler R, Ticha A, Hrnciarikova D, Zadak Z. Hypocholesterolemia in clinically serious conditions--review. Biomed Pap Med Fac Univ Palacky Olomouc Czech Repub. 2008; 152(2):181-9.

Weiss R, Dziura J, Burgert TS, Tamborlane WV, Taksali SE, Yeckel CW, Allen K, Lopes M, Savoye M, Morrison J, Sherwin RS, Caprio S. Obesity and the metabolic syndrome in children and adolescents. N Engl J Med. 2004; 350(23):2362-74.

Wendel M, Paul R, Heller AR. Lipoproteins in inflammation and sepsis. II. Clinical aspects. Intensive Care Med. 2007; 33(1):25-35. 
Wiesner P, Choi SH, Almazan F, Benner C, Huang W, Diehl CJ, Gonen A, Butler S, Witztum JL, Glass CK, Miller YI. Low doses of lipopolysaccharide and minimally oxidized low-density lipoprotein cooperatively activate macrophages via nuclear factor kappa B and activator protein-1: possible mechanism for acceleration of atherosclerosis by subclinical endotoxemia. Circ Res. 2010; 107(1):56-65.

Wilson RF, Barletta JF, Tyburski JG. Hypocholesterolemia in sepsis and critically ill or injured patients. Crit Care. 2003; 7(6):413-4.

Xavier HT, Izar MC, Faria Neto JR, Assad MH, Rocha VZ, Sposito AC, Fonseca FA, dos Santos JE, Santos RD, Bertolami MC, Faludi AA, Martinez TLR, Diament J, Guimarães A, Forti NA, Moriguchi E, Chagas ACP, Coelho OR, Ramires JAF; Sociedade Brasileira de Cardiologia. V Diretriz Brasileira de Dislipidemias e Prevenção da Aterosclerose. Arq Bras Cardiol. 2013; 101(4 Suppl 1):1-20.

Yildiz B, Ucar B, Aksit A, Aydogdu SD, Colak O, Colak E. Diagnostic values of lipid and lipoprotein levels in late onset neonatal sepsis. Scand J Infect Dis. 2009; 41(4):263-7.

Zyblewski SC, Argraves WS, Graham EM, Slate EH, Atz AM, Bradley SM, McQuinn TC, Wilkerson BA, Wing SB, Argraves KM. Reduction in postoperative high-density lipoprotein cholesterol levels in children undergoing the Fontan operation. Pediatr Cardiol. 2012; 33(7):1154-9. 


\section{APÊNDICES}




\section{Apêndice A - Submissão artigo}

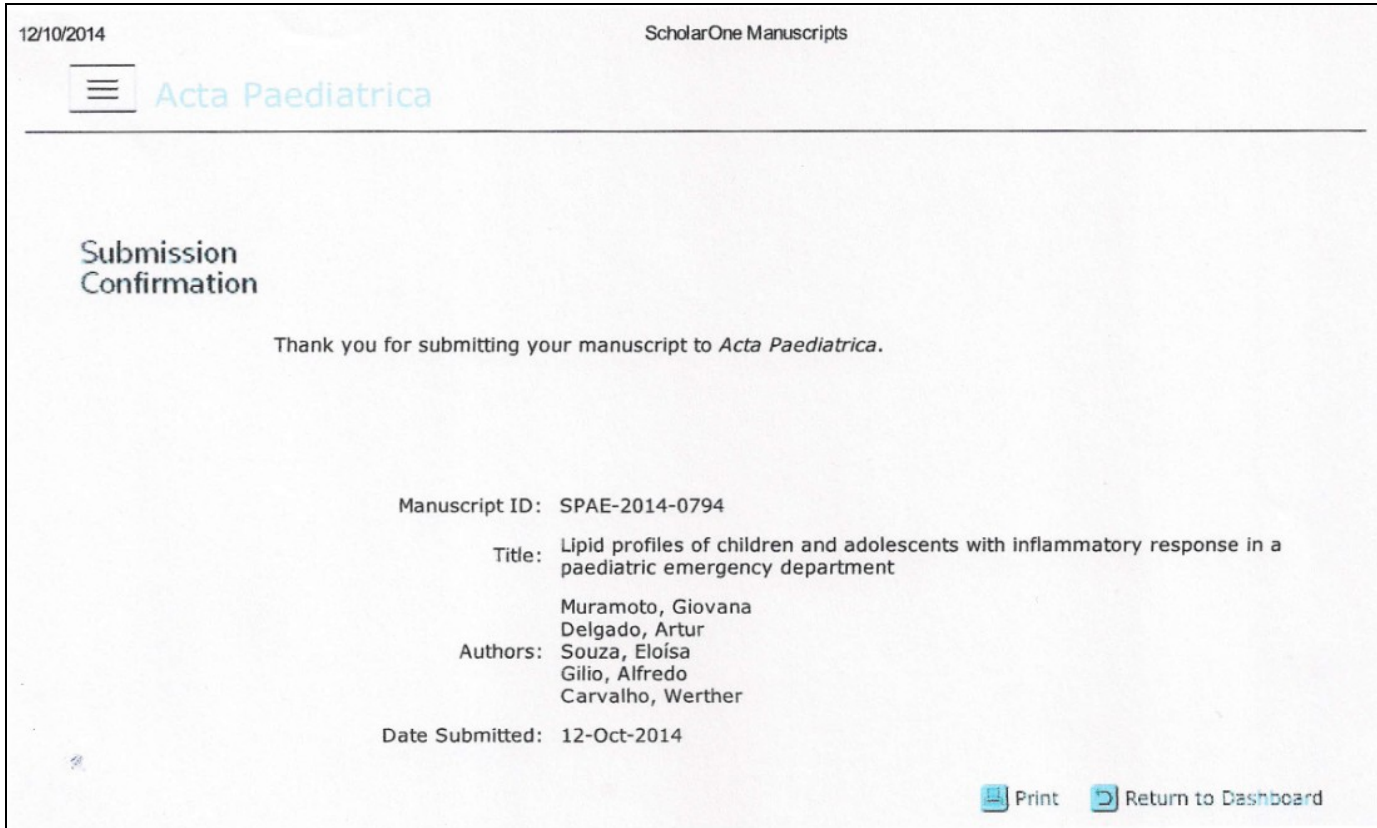




\section{Apêndice B - Artigo submetido}

Lipid profiles of children and adolescents with inflammatory response in a paediatric emergency department

Muramoto, G; Delgado, AF; Souza, EC; Gilio, AE; Carvalho, WB; Maranhão, RC

\section{ABBREVIATIONS}

ALB: albumin

Apo: apolipoprotein

ATS: atherosclerosis

CRP: C-reactive protein

HDL: high-density lipoprotein

ICU: intensive care unit

IDL: intermediate density lipoprotein

LDL: low-density lipoprotein

SBC: Brazilian Society of Cardiology

SIRS: systemic inflammatory response syndrome

TC: Total cholesterol

TG: triglyceride

TNF-a: tumour necrosis factor alpha

VLDL: very low-density lipoprotein

\section{ABSTRACT}

Aim: To compare the lipid profile between patients with and without inflammatory process in according nutritional status, gender and age.

Methods: 124 children and adolescents in the emergency department were separated into two groups according to the levels of C-reactive protein (CRP). Total cholesterol, high density lipoprotein (HDL) and low density (LDL), triglycerides and albumin in patients with $C R P<5 \mathrm{mg}$ / $\mathrm{L}$ were compared to patients with $C R P \geq 5 \mathrm{mg} / \mathrm{L}$. Nutritional status was assessed by anthropometric measurements.

Results: Patients were mostly classified as well-nourished (76.5\%) and had low levels of HDL (70\%). There was no significant difference in lipid profile between the two groups of CRP. Linear regression analysis, however, it became clear that for each increase of $1 \mathrm{mg}$ $/ \mathrm{L}$ in the values of CRP expected an average reduction of $0,072 \mathrm{mg} / \mathrm{dL}$ of $\mathrm{HDL}$, the $0,083 \mathrm{mg} / \mathrm{dL}$ of LDL, the $0,002 \mathrm{~g} / \mathrm{dL}$ albumin, and an average increase of $0,564 \mathrm{mg} / \mathrm{dL}$ of triglycerides. 
Conclusion: Patients with an inflammatory process exhibit changes in the serum levels of the lipids HDL, LDL and TG that are related to the degree of inflammation. These changes occurred regardless of nutritional status.

\section{INTRODUCTION}

Childhood hyperlipidaemia is a predisposing factor for atherosclerosis (ATS) and the development of heart disease in adulthood (1). Risk factors such as hyperglycaemia, diabetes and hypertension in childhood are also important for the development of atherosclerosis in adulthood (2).

The evaluation of the lipid profile and the early treatment for hyperlipidaemia and other ATS risk factors during childhood may prevent the development of cardiovascular diseases $(3,4)$.

Clinical conditions that show inflammation also temporarily affect the lipid profile. Patients with sepsis and systemic inflammatory response syndrome (SIRS) have increased levels of triglycerides (TG) and decreased levels of high density (HDL), low density (LDL) and very low-density (VLDL) lipoprotein in the first 24 hours following admission $(5,6)$. Changes in the lipid profile during infection are most pronounced in the first 72 hours; however, it may take more than seven days to return to pre-infection values (7)

A few studies have observed similar changes in the lipid profile of paediatric patients with a history of localized infection and have found that these changes are related to the process of atherogenesis (8). HDL plays a protective role against the development of atherosclerosis. HDL participates in the removal of cholesterol in the blood vessels and promotes reverse cholesterol transport from the peripheral tissues to the liver (9).

HDL also has an important role as a modulator of the systemic inflammatory response, among its many other functions. It plays an important role in neutralizing lipopolysaccharides during bacterial infection and acts on monocytes and macrophages to inhibit antigen presentation and suppress cytokine and chemokine production. HDL may contain proteins linked to the acute phase inflammatory response, lipid metabolism, activation of the complement system, regulation of tumour growth factor and proteolysis $(10,11)$.

To examine the changes in the lipid profile, particularly in HDL, LDL and TG, in the early phases of the inflammatory process, which may or may not be associated with infection, we evaluated these indicators in children and adolescents treated in the paediatric emergency department of a secondary care teaching hospital. 
METHODS

Population

This study was conducted in infants, children and adolescents who were treated in the paediatric emergency department of a teaching hospital, which treat an average of 188 patients per day.

\section{Calculation of sample size}

The sample size was calculated to find a difference of at least $10 \mathrm{mg} / \mathrm{dL}$ in HDL levels in children with or without an inflammatory reaction, assuming the variability of $\mathrm{HDL}$ to be approximately $15 \mathrm{mg} / \mathrm{dL}$, with a $95 \%$ confidence interval and $80 \%$ test power. The tests were performed with a $5 \%$ significance level.

\section{Study Design}

This is a cross-sectional study in which the lipid profile of patients with infectionrelated complaints was analysed and the degree of inflammation was compared according to nutritional status, gender and age. Data collection was conducted from October 2012 to August 2013

The study included patients between the ages of three months to 14 years old who were treated in the emergency department with a presumed diagnosis of an inflammatory reaction (primarily of infectious cause). Patients with a history of liver disease, dyslipidaemia or diabetes mellitus, patients who reported the use of high doses of corticosteroids and those whose caregivers did not sign the informed consent form were excluded.

The patients were divided into two groups for analysis based on their $\mathrm{C}$-reactive protein (CRP) values, an important inflammatory marker. Group I, or the "with inflammation" patients, had a CRP value higher than or equal to $5 \mathrm{mg} / \mathrm{L}$, and group II, or the "without inflammation" patients, had CRP values lower than $5 \mathrm{mg} / \mathrm{L}$.

During treatment in the emergency department, each patient's total cholesterol (TC), HDL, LDL, TG, CRP, glucose, total protein and protein fractions were measured. The biological material was processed at the laboratory of the University Hospital of the University of São Paulo - Brazil (HU-USP), using the following methods: automated cholesterol oxidase for TC, automated direct for HDL, the Friedewald equation for LDL, automated peroxidase glycerol for TG, automated biuret for total protein, automated bromocresol green for albumin (ALB) and nephelometry for CRP (CardioPhase ${ }^{\circledR}$ hSCRP 
Siemens Healthcare Diagnostics). Capillary blood glucose was measured using the Accu-Chek@ device.

The results of the laboratory tests and nutritional status classification were compared between groups I and II. The differences were also analysed by age and gender.

The results for the patients' lipid profiles were interpreted based on the recommendations of the Expert Panel on Integrated Guidelines for Cardiovascular Health and Risk Reduction in Children and Adolescents (12) and the $V$ Brazilian Guidelines for Dyslipidaemia and Atherosclerosis Prevention of the Brazilian Society of Cardiology (Sociedade Brasileira de Cardiologia - SBC) (13). Lipid values were considered normal within the following ranges: $T C<170 \mathrm{mg} / \mathrm{dL}, \mathrm{LDL}<110 \mathrm{mg} / \mathrm{dL}, T G<90$ $\mathrm{mg} / \mathrm{dL}$ and $\mathrm{HDL}>45 \mathrm{mg} / \mathrm{dL}$. Borderline and higher values were considered abnormal.

For the nutritional evaluation, the patients were classified into three groups according to their anthropometric measurements, specifically weight and height, body mass index (BMI) and Z-score: normal or well nourished, overweight/obese and underweight/extremely underweight. The nutritional classification of the patient was determined according to the growth curves of the World Health Organization (WHO) (14).

The flowchart below summarises the study design.

PAEDIATRIC EMERGENCY DEPARTMENT SECONDARY CARE TEACHING HOSPITAL

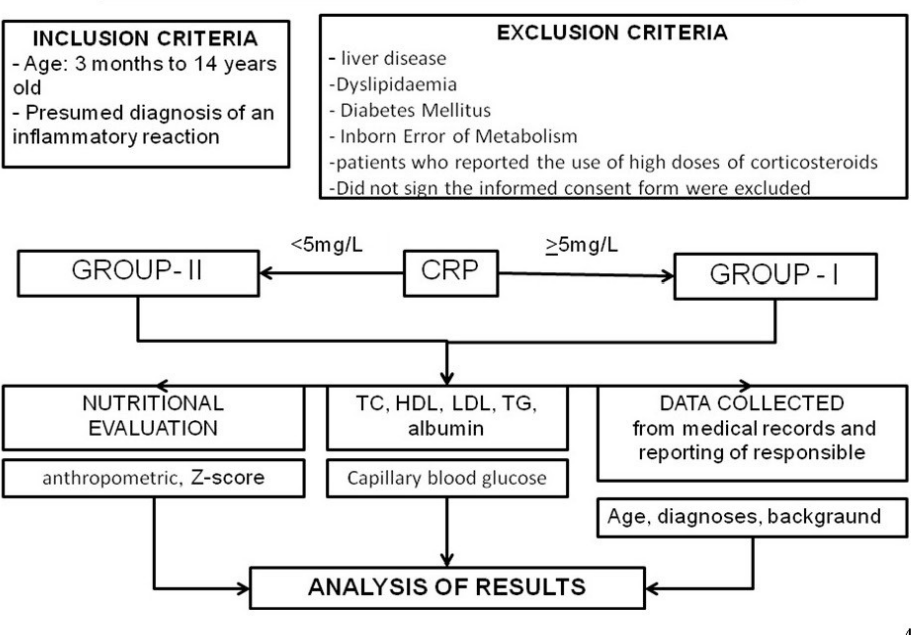


Statistical analysis

The qualitative variables and lipid profile classifications were described using absolute and relative frequencies, while the quantitative variables were described using means and standard deviations (SD). Personal characteristics, nutritional status classification and characterization of lipid profiles were described using summary measures (mean, SD, median, minimum and maximum) and compared between groups I and II using Student's t-test.

For patients with $C R P \geq 5 \mathrm{mg} / \mathrm{L}$, Spearman's correlations between the lipid profile and the following variables were calculated: CRP, nutritional status and personal characteristics. Linear regression models were fit for variables that had a significant correlation, and only the variables with descriptive levels below $5 \%(p<0.05)$ remained in the final models.

\section{RESULTS}

A total of 129 patients were considered eligible for the study. Two patients were lost (insufficient biological samples for CRP measurement) and three patients did not have anthropometric measurements taken. Therefore, of the 129 eligible patients, 124 were included in the analysis.

The overall sample analysis revealed that the sample comprised 60 (48.5\%) female and 64 (51.5\%) male patients. The median age of the patients included in the study was 51 months. In regard to the nutritional status, $76.5 \%$ of patients were classified as normal, $17 \%$ as overweight or obese and $6.5 \%$ as underweight or extremely underweight.

Regarding the lipid concentrations, the results were within the range considered normal of $65 \%$ for TC, $81 \%$ for LDL, and $81 \%$ for TG. As for the HDL concentrations, the majority of patients $(70 \%)$ had serum concentrations below the values considered normal. The laboratory results are shown in Figure 1

Figure 1. Lipids profile results (total sample) 


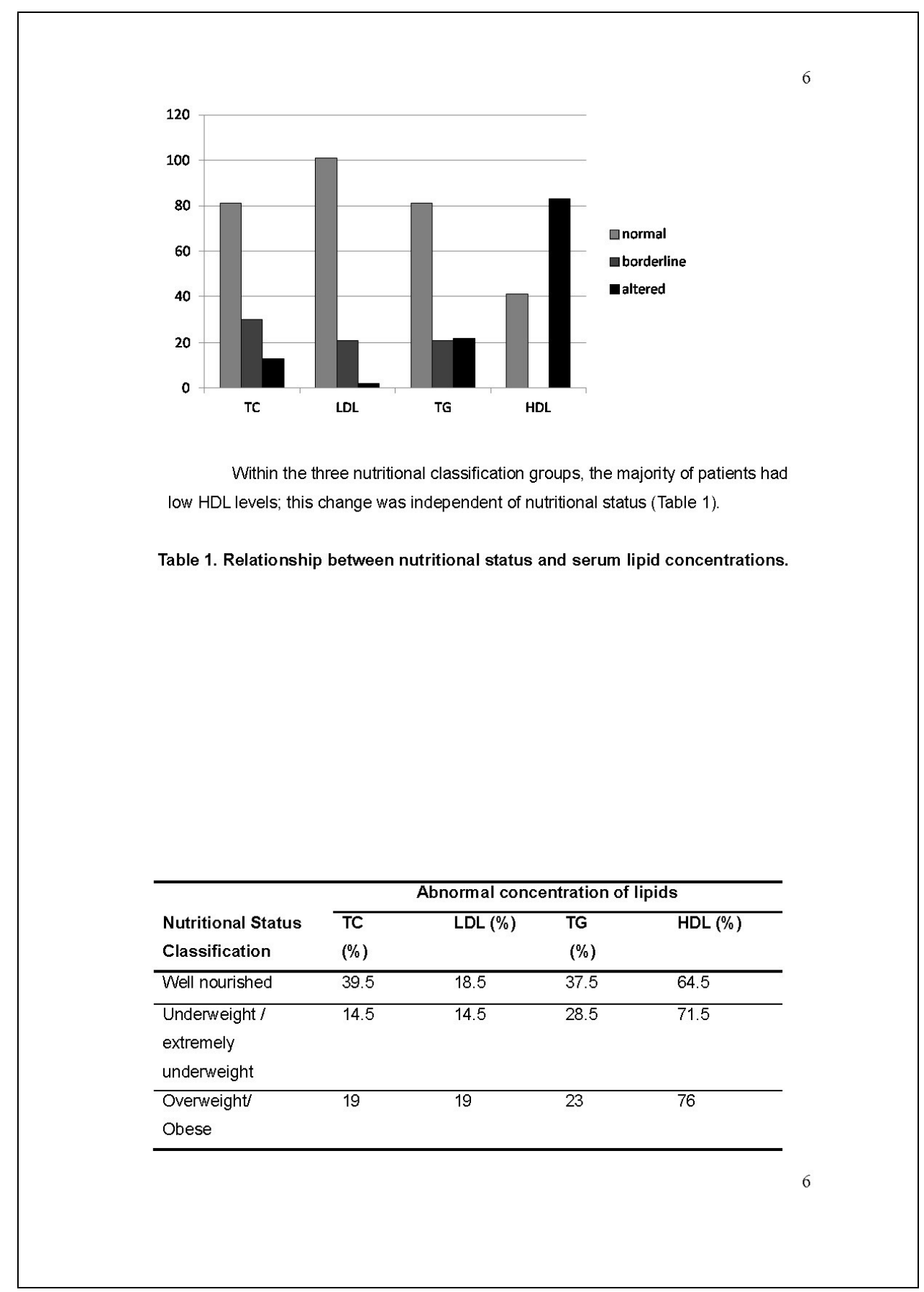


Of the patients with abnormal levels of TC, $79 \%$ were well nourished, $21 \%$ were overweight or obese, and none were considered underweight or extremely underweight. Among the patients with low concentrations of $\mathrm{HDL}, 76 \%$ were well nourished, $18 \%$ were overweight or obese, and $6 \%$ were underweight or extremely underweight (Table 2).

Table 2. The nutritional status of patients with abnormal concentration of TC and HDL.

\begin{tabular}{ccc}
\multicolumn{3}{c}{ Nutritional Classification Groups } \\
\hline well & Overweight/ & underweight/ \\
nourished & obese & extremely \\
$(\%)$ & $(\%)$ & underweight
\end{tabular}

(\%)

Lipids

\begin{tabular}{llll}
\hline Abnormal CT & 80 & 20 & 0 \\
\hline Abnormal HDL & 76 & 18 & 6 \\
\hline
\end{tabular}

The mean blood glucose level was $106.9 \mathrm{mg} / \mathrm{dL}(\mathrm{SD}=26.8)$, with a minimum value of $56 \mathrm{mg} / \mathrm{dL}$ and a maximum value of $288 \mathrm{mg} / \mathrm{dL}$. Nineteen patients $(23.5 \%)$ had blood glucose values above $126 \mathrm{mg} / \mathrm{dL}$.

The main diagnosis of the patients were pneumonia, dengue virus infection, fever on unknown in children, acute diarrhoea, cellulitis, impetigo, acute appendicitis, urinary tract infection and pyelonephritis.

According to the CRP values, 82 patients were included in group I (CRP $\geq 5$ $\mathrm{mg} / \mathrm{L}$ ) and 42 patients in group II (CRP<5 mg/L). When comparing the two groups, there was no significant difference for the variables age, gender, nutritional status, serum albumin and lipid profile (TC, HDL, LDL and TG). Only capillary blood glucose was significantly higher in group I compared to group II $(p=0.01)$ (Table 3$)$.

Table 3: Comparison of the Student's t-test results for the groups I and II.

\begin{tabular}{llll}
\hline & Group II & Group I & P \\
& PCR<5mg/L & PCR $\geq 5 \mathrm{mg} / \mathrm{L}$ \\
\cline { 2 - 3 } Variables & means & means \\
\hline
\end{tabular}




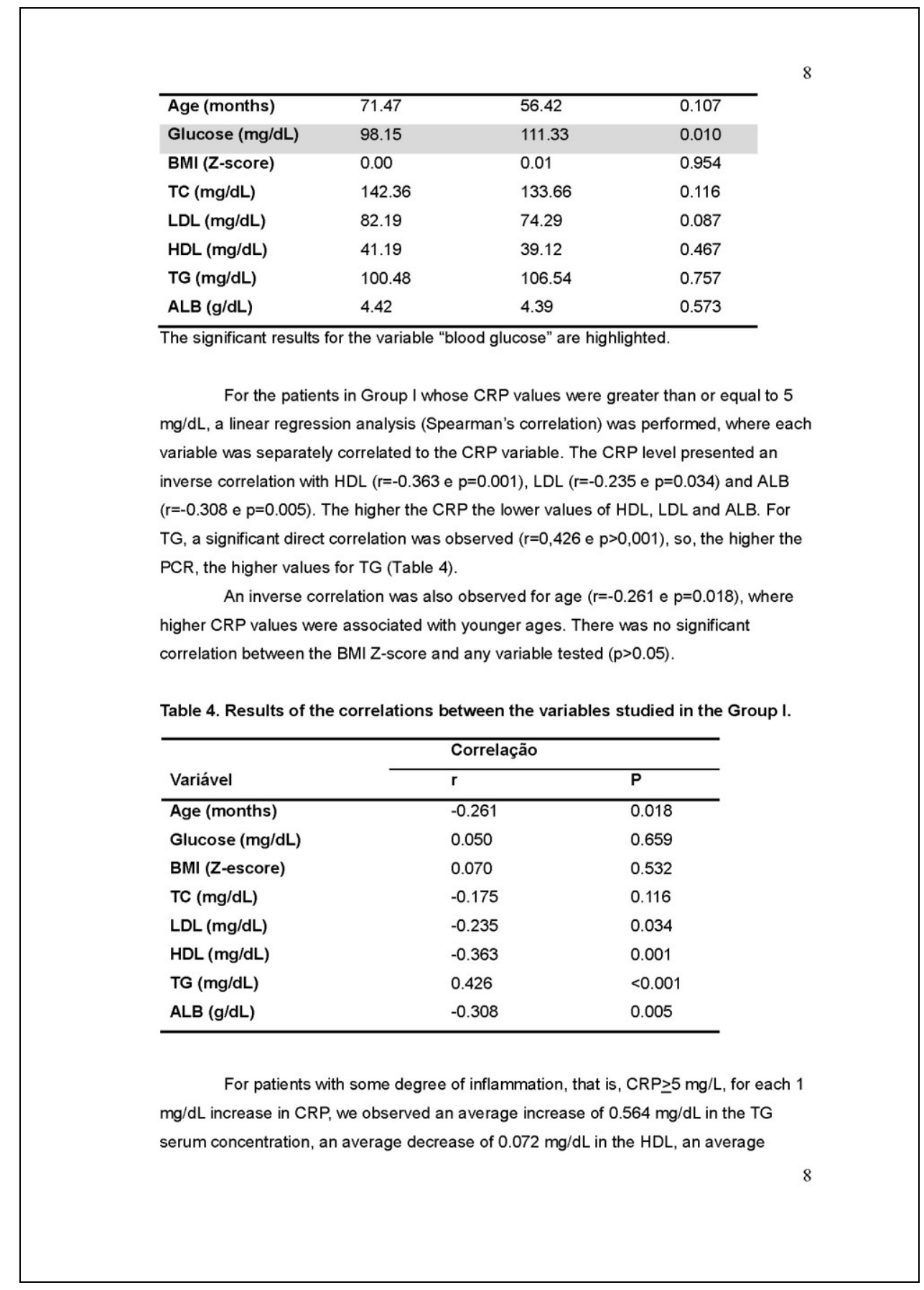


decrease of $0.083 \mathrm{mg} / \mathrm{dL}$ in the LDL and an average decrease of $0.002 \mathrm{~g} / \mathrm{dL}$ in the ALB, regardless of the other characteristics evaluated in this group (Table 5).

Table 5. Results of the regression models for lipid profile variables according to the CRP serum concentration.

\begin{tabular}{|c|c|c|c|c|c|c|}
\hline Variable & Factor & Estimate & $\begin{array}{l}\text { Standard } \\
\text { error }\end{array}$ & t-test & $p$ & R2 \\
\hline \multirow{3}{*}{$\begin{array}{l}\text { LDL } \\
(\mathrm{mg} / \mathrm{dL})\end{array}$} & Constant & 80.924 & 3.425 & 23.63 & $2<0.001$ & \multirow{3}{*}{0.091} \\
\hline & CRP & & & & & \\
\hline & $(\mathrm{mg} / \mathrm{L})$ & -0.083 & 0.029 & -2.84 & 0.006 & \\
\hline \multirow{5}{*}{$\begin{array}{l}\mathrm{HDL} \\
(\mathrm{mg} / \mathrm{dL})\end{array}$} & Constant & 40.397 & 2.909 & 13.89 & $<0.001$ & \multirow{5}{*}{0.292} \\
\hline & Age & & & & & \\
\hline & (months) & 0.079 & 0.032 & 2.49 & 0.015 & \\
\hline & CRP & & & & & \\
\hline & $(\mathrm{mg} / \mathrm{L})$ & -0.072 & 0.017 & -4.21 & $<0.001$ & \\
\hline \multirow{3}{*}{$\begin{array}{l}\text { TG } \\
(\mathrm{mg} / \mathrm{dL})\end{array}$} & Constant & 61.185 & 16.499 & 3.71 & $<0.001$ & \multirow{3}{*}{0.168} \\
\hline & CRP & & & & & \\
\hline & $(\mathrm{mg} / \mathrm{L})$ & 0.564 & 0.140 & 4.03 & $<0.001$ & \\
\hline \multirow{3}{*}{$\begin{array}{l}\text { ALB } \\
(\mathrm{g} / \mathrm{dL})\end{array}$} & Constant & 4.547 & 0.048 & 95.37 & $<0.001$ & \multirow{3}{*}{0.231} \\
\hline & CRP & & & & & \\
\hline & $(\mathrm{mg} / \mathrm{L})$ & -0.002 & 0.000 & -4.90 & $<0.001$ & \\
\hline
\end{tabular}

\section{DISCUSSION}

In the present study, performed in a university hospital of a developing country, the concentrations of TC, LDL and TG were normal in the majority of patients. The percentage of patients who exhibited changes in the lipid profile was similar to the results found in other studies that evaluated the lipid concentration and nutritional status of children and adolescents $(15,16,17,18)$. In the United States, according to data from the National Health and Nutrition Examination Survey (NHANES), from 1999 to 2006, there was a $20.6 \%$ prevalence of dyslipidaemia in children from 6 to 19 years of age Overweight and obese children were 1.6 and 3 times more prone to dyslipidaemia, respectively (15). Between 2007 and 2010, there was a significant decrease in cholesterol levels in $10 \%$ of children from 6 to 19 years old and a decrease in hypertriglyceridemia from $11.3 \%$ to $8.1 \%$, attributed to the establishment of prevention strategies in the American population between these periods (16). In Brazil, in the city of Campinas, São Paulo, the lipid profile in 1,600 schoolchildren from 7 to 14 years of age 
indicated that $35 \%$ had hypercholesterolemia (TC>170 mg/dL) (17). In 2001, in the city of Florianópolis, Santa Catarina - Brazil, an assessment of 1,053 children between 7 and 18 years of age found hypercholesterolemia in $10 \%$ and hypertriglyceridemia in $22 \%$ (18).

Obesity can be associated with dyslipidaemia in children $(18,19)$. In this study, no association between the lipid profile and nutritional status was found. The percentage of patients with an abnormal lipid profile was similar among the different nutritional status groups. Most patients who had abnormal TC, TG and HDL levels were considered well nourished.

Patients with severe acute systemic inflammation, SIRS and sepsis have acute changes in their lipid profile $(5,6,11)$. Minor acute infections also decrease the levels of HDL and LDL, as described in a study conducted in normal-BMI individuals from 9 to 21 years of age. The authors compared the HDL, LDL, TC and inflammatory status (CRP and orosomucoid concentration) of individuals with mild infections to a control group without infection, but didn't included nutritional evaluation and information about health status (8).

In the present study, no significant differences in the mean values for TC, LDL, HDL and TG were detected when comparing groups I and II. However there was a significant difference in blood glucose between the two groups, which can be explained by hormonal changes that occur during the acute phase of the inflammatory process. Changes in the lipid profile during sepsis also occur acutely, but are independent from the blood glucose levels during the inflammatory process (20).

In the Group I, a significant correlation was observed between the lipid levels and the intensity of inflammation, indicating that the higher the CRP, the higher the TG and the lower the HDL, LDL and ALB. Similar results were found in adults patients admitted in intensive care unit with intense inflammatory state, SIRS or sepsis (21). In paediatrics, a study has also shown similar acute changes in the lipid profile that was associated with mortality in children with a meningococcal infection (22).

A very important characteristic observed in the lipid profile of the total sample was that most patients $(70 \%)$ had abnormal HDL levels. This result differs from other studies in Brazilian children and adolescents without inflammatory process that reported a mean $\mathrm{HDL}$ value that is within the normal range $(14,15)$. Mild acute infectious processes can be responsible for the decreased HDL levels (8). This result is very important when considering that $\mathrm{HD}$ can be a biomarker and plays a protective role during the infectious process. A study in hospitalized adults showed that for every 1 $\mathrm{mg} / \mathrm{dL}$ increase in HDL levels, the chance of severe sepsis decreased by $3 \%$ (23). Low 
HDL levels in adults with sepsis were associated with higher mortality and a longer ICU stay (24).

In addition, it should be emphasized that HDL is responsible for esterification and reverse cholesterol transport (i.e., from the tissues to the liver) (25). In this process, HDL promotes the removal of oxidized lipids from LDL, inhibits the attachment of adhesion molecules and of monocytes to the endothelium and stimulates nitric oxide release (26). A study conducted in children who were hospitalized with acute infection showed that decreased HDL levels in the first 24 hours of infection may have a correlation with the thickening of the intimal layer of the carotid artery, observed by ultrasound, when compared with a control group. In that study, the thickening of the carotid artery was greater in individuals who did not receive antibiotics (faster resolutions of inflammatory and infection process) (27).

The role of HDL during the initial phase of the inflammation process and the mechanisms by which a decrease in HDL circulating levels occurs are not well defined. Recent studies involving proteomic analysis of HDL showed that patients with different diseases (such as rheumatoid arthritis, coronary artery disease, chronic renal failure and psoriasis) have HDL with different protein compositions, reinforcing the important, but still unknown, function of this lipoprotein in inflammation (28).

Human and animal studies have demonstrated a beneficial effect of higher levels of circulating $\mathrm{HDL}$ and apo $\mathrm{Al}$, (the main apolipoprotein bound to $\mathrm{HDL}$ ), including an improved immune response against severe systemic infections $(29,30)$.

Administration of apo $\mathrm{Al}$ in animals with severe infection reduced the production of inflammatory mediators and mortality in some of these studies, and can be a promise in future human research $(31,32,33)$.

The main strength of this was to perform a comparison lipids profile and nutritional evaluation between children and adolescents with inflammatory process (including mild cases) and without inflammation. The main limitations were: single nutritional evaluation; no evaluation of other lipid parameters (apolipoproteins) and evaluation of inflammatory process based on exclusively in PCR concentrations.

\section{CONCLUSIONS}

Patients with an inflammatory process exhibit changes in the serum levels of the lipids HDL, LDL and TG that are related to the degree of inflammation. These changes occurred regardless of nutritional status. 
REFERENCES

1) Raitakari OT, Juonala M, Kahonen M, Taittonen L, Laitinen T, Maki-Torkko N, et al. Cardiovascular risk factors in childhood and carotid artery intima-media thickness in adulthood - The Cardiovascular Risk in Young Finns Study. Jama-Journal of the American Medical Association. 2003;290(17):2277-83.

2) Morrison JA, Glueck CJ, Wang P. Childhood risk factors predict cardiovascular disease, impaired fasting glucose plus type 2 diabetes mellitus, and high blood pressure 26 years later at a mean age of 38 years: the Princeton-lipid research clinics follow-up study. Metabolism-Clinical and Experimental. 2012;61(4):531-41.

3) Magnussen CG, Koskinen J, Juonala M, Chen W, Srinivasan SR, Sabin MA, et al. A Diagnosis of the Metabolic Syndrome in Youth That Resolves by Adult Life Is Associated With a Normalization of High Carotid Intima-Media Thickness and Type 2 Diabetes Mellitus Risk The Bogalusa Heart and Cardiovascular Risk in Young Finns Studies. Journal of the American College of Cardiology. 2012;60(17):1631-9.

4) Juonala M, Jarvisalo MJ, Maki-Torkko N, Kahonen M, Viikari JSA, Raitakari OT. Risk factors identified in childhood and decreased carotid artery elasticity in adulthood - The cardiovascular risk in Young Finns Study. Circulation. 2005;112(10):1486-93.

5) Alvarez C, Ramos A. LIPIDS, LIPOPROTEINS, AND APOPROTEINS IN SERUM DURING INFECTION. Clinical Chemistry. 1986;32(1):142-5.

6) Chenaud C, Merlani PG, Roux-Lombard P, Burger D, Harbarth S, Luyasu S, et al. Low apolipoprotein A-I level at intensive care unit admission and systemic inflammatory response syndrome exacerbation. Critical Care Medicine. 2004;32(3):632-7.

7) Gidding SS, Stone NJ, Bookstein LC, Laskarzewski PM. Month-to-month variability of lipids, lipoproteins, and apolipoproteins and the impact of acute infection in adolescents. Journal of Pediatrics. 1998;133(2):242-6.

8) Aburawi EH, Grubb A, Raitakari OT, Viikari J, Pesonen EJ. Lowered levels of serum albumin and HDL-cholesterol in children with a recent mild infection. Annals of Medicine. 2006;38(2):154-60.

9) Soran H, Hama S, Yadav R, Durrington PN. HDL functionality. Current Opinion in Lipidology. 2012;23(4):353-66.

10) Murch $O$, Collin M, Hinds CJ, Thiemermann C. Lipoproteins in inflammation and sepsis. I. Basic science. Intensive Care Medicine. 2007;33(1):13-24.

11) Chiarla C, Giovannini I, Giuliante F, Zadak Z, Vellone M, Ardito F, et al. Severe hypocholesterolemia in surgical patients, sepsis, and critical illness. Journal of Critical Care. 2010; 25(2). 
12) Expert panel on integrated guidelines for cardiovascular health and risk reduction in children and adolescents [on-line] . National Heart, Lung, and Blood Institute; 2012 Oct. Available from: http://www.nhlbi.nih.gov/guidelines/cvd_ped/index.htm.[Accessed on 19 Jun 2014].

13) Xavier HT, Izar MC, Faria Neto JR, Assad MH, Rocha VZ, Sposito AC, et al. V Diretriz Brasileira de Dislipidemias e Prevenção da Aterosclerose. Arquivos Brasileiros de Cardiologia. 2013;101(4):1-20.

14) WHO child growth Standards [on-line]. Available from: http://www.who.int/childgrowth/standards/bmi_for_age/en/e http://www.who.int/growthref/who2007_bmi_for_age/en/ acess in 22 april, 2014.

15) May AL, Kuklina EV, Yoon PW. Prevalence of Abnormal Lipid Levels Among Youths-United States, 1999-2006 (Reprinted from MMWR, vol 59, pg 29-33, 2010). Jama-Journal of the American Medical Association. 2010; 303(10):930-3.

16) Kit BK, Carroll MD, Lacher DA, Sorlie PD, DeJesus JM, Ogden CL. Trends in Serum Lipids Among US Youths Aged 6 to 19 Years, 1988-2010. Jama-Journal of the American Medical Association. 2012;308(6):591-600.

17) Moura EC, de Castro CM, Mellin AS, de Figueiredo DB. Lipidic profile among schoolchildren, Brazil. Revista De Saude Publica. 2000; 34(5):499-505.

18) Giuliano IdCB, Coutinho MSSdA, Freitas SFTd, Pires MMdS, Zunino JN, Ribeiro RQdC. Lípides séricos em crianças e adolescentes de Florianópolis, SC: Estudo Floripa saudável 2040. Arquivos Brasileiros de Cardiologia. 2005;85(2):85-91.

19) Alcântara Neto ODd, Silva RdCR, Assis $A M O$, Pinto EdJ. Fatores associados à dislipidemia em crianças e adolescentes de escolas públicas de Salvador, Bahia. Revista Brasileira de Epidemiologia. 2012;15(2):335-45.

20) Cappi SB, Noritomi DT, Velasco IT, Curi R, Loureiro TCA, Soriano FG. Dyslipidemia: a prospective controlled randomized trial of intensive glycemic control in sepsis. Intensive Care Medicine. 2012;38(4):634-41.

21) van Leeuwen HJ, Heezius E, van Strijp JAG, van Kessel KPM, Dallinga GM, Verhoef J. Lipoprotein metabolism in patients with severe sepsis. Critical Care Medicine. 2000; 28(12):A133-A.

22) Vermont $C L$, den Brinker $M$, Kakeci $N$, de Kleijn ED, de Rijke YB, Joosten KFM, et al. Serum lipids and disease severity in children with severe meningococcal sepsis. Critical Care Medicine. 2005;33(7):1610-5.

23) Grion CMC, Cardoso LTQ, Perazolo TF, Garcia AS, Barbosa DS, Morimoto HK, et al. Lipoproteins and CETP levels as risk factors for severe sepsis in hospitalized patients. European Journal of Clinical Investigation. 2010; 40(4):330-8.

24) Chien JY, Jerng JS, Yu CJ, Yang PC. Low serum level of high-density lipoprotein 
cholesterol is a poor prognostic factor for severe sepsis. Critical Care Medicine. 2005;33(8):1688-93.

25) Tall AR. PLASMA HIGH-DENSITY LIPOPROTEINS - METABOLISM AND RELATIONSHIP TO ATHEROGENESIS. Journal of Clinical Investigation. 1990;86(2):379-84.

26) Rosenson RS, Brewer HB, Jr., Davidson WS, Fayad ZA, Fuster V, Goldstein J, et al. Cholesterol Efflux and Atheroprotection Advancing the Concept of Reverse Cholesterol Transport. Circulation. 2012; 125(15):1905-19.

27) Liuba P, Persson J, Luoma J, Yla-Herttuala S, Pesonen E. Acute infections in children are accompanied by oxidative modification of LDL and decrease of HDL cholesterol, and are followed by thickening of carotid intima-media. European Heart Journal. 2003;24(6):517-23.

28) Marsche G, Saemann MD, Heinemann A, Holzer M. Inflammation alters HDL composition and function: Implications for HDL-raising therapies. Pharmacology \& Therapeutics. 2013; 137(3):341-51.

29) Hudgins LC, Parker TS, Levine DM, Gordon BR, Saal SD, Liang XC, et al. A single intravenous dose of endotoxin rapidly alters serum lipoproteins and lipid transfer proteins in normal volunteers. Journal of Lipid Research. 2003;44(8):1489-98.

30) Birjmohun RS, van Leuven SI, Levels JHM, van 't Veer C, Kuivenhoven JA, Meijers JCM, et al. High-density lipoprotein attenuates inflammation and coagulation response on endotoxin challenge in humans. Arteriosclerosis Thrombosis and Vascular Biology. 2007;27(5):1153-8.

31) Imai T, Fujita T, Yamazaki Y. Beneficial effects of apolipoprotein A-I on endotoxemia. Surgery Today. 2003;33(9):684-7.

32) Jiao $Y-I$, Wu M-P. Apolipoprotein A-I diminishes acute lung injury and sepsis in mice induced by lipoteichoic acid. Cytokine. 2008;43(1):83-7.

33) Guo L, Ai J, Zheng Z, Howatt DA, Daugherty A, Huang B, et al. High Density Lipoprotein Protects against Polymicrobe-induced Sepsis in Mice. Journal of Biological Chemistry. 2013;288(25):17947-53. 